\title{
Microbial ecology of freshly sawn yellow-poplar lumber ( Liriodendron tulipifera L.) in two seasons
}

\author{
Mark Ryan Mikluscak \\ West Virginia University
}

Follow this and additional works at: https://researchrepository.wvu.edu/etd

\section{Recommended Citation}

Mikluscak, Mark Ryan, "Microbial ecology of freshly sawn yellow-poplar lumber ( Liriodendron tulipifera L.) in two seasons" (2002). Graduate Theses, Dissertations, and Problem Reports. 1236.

https://researchrepository.wvu.edu/etd/1236

This Thesis is protected by copyright and/or related rights. It has been brought to you by the The Research Repository @ WVU with permission from the rights-holder(s). You are free to use this Thesis in any way that is permitted by the copyright and related rights legislation that applies to your use. For other uses you must obtain permission from the rights-holder(s) directly, unless additional rights are indicated by a Creative Commons license in the record and/ or on the work itself. This Thesis has been accepted for inclusion in WVU Graduate Theses, Dissertations, and Problem Reports collection by an authorized administrator of The Research Repository @ WVU. For more information, please contact researchrepository@mail.wvu.edu. 


\title{
MICROBIAL ECOLOGY OF FRESHLY SAWN YELLOW-POPLAR LUMBER (Liriodendron tulipifera L.) IN TWO SEASONS
}

\author{
Mark R. Mikluscak
}

Thesis submitted to the College of Agriculture and Forestry and Consumer Sciences at West Virginia University in partial fulfillment of the requirements for the degree of

\author{
Master of Science \\ in \\ Forestry \\ Benjamin Dawson-Andoh, Ph.D., Chair \\ William MacDonald, Ph.D. \\ James Armstrong, Ph.D. \\ Wojciech Janisiewicz, Ph.D. \\ Division of Forestry \\ Morgantown, WV \\ 2002
}

Keywords: Microbial Ecology, Biological Control, Fungi, Bacteria, Yeast, Lumber 


\section{ABSTRACT \\ Microbial Ecology of Freshly Sawn Yellow-poplar Lumber (Liriodendron tulipifera L.) in Two Seasons \\ Mark R. Mikluscak}

Each year, the forest products industry sustains considerable product loss due to a reduction in market value of lumber brought about by microbial discoloration. The current practice of treating green lumber with chemical biocides to protect it from discoloration, although successful, is a potential hazard to both the environment and human life. One potential alternative to chemical biocides is biological control. The most recent success in the field of biological control has been achieved in the agricultural industry by first studying the microbial ecology of the substrate in which the biologically based preservative is to be used. Literature on microbial ecology of green lumber and how to control the colonization on it biologically is very limited. Consequently, the primary objective of this study was to gain a general understanding of the microbial ecology of green lumber of yellow-poplar (Liriodendron tulipifera L.) during storage as a precursor to the development of biological control agents for use on freshly sawn lumber.

This thesis consists of five chapters. Chapter one is an introduction and chapter two reviews relevant literature. Chapters three, four, and five describe the procedures used and results obtained for fungi, bacteria, and yeast, respectively, colonizing freshly sawn (green) yellow-poplar lumber in spring and summer of 2000. In chapters three through five, wood samples taken from lumber arranged and stored in a dead-stack configuration were examined by dilution plating for each focus microorganism. The total abundance of fungi and bacteria ( $\log _{n} \mathrm{CFU} /$ gram) represented the largest portion of the microbial community and accounted for $41 \%$ and $43 \%$, respectively, of the total population of microflora isolated. Of the 427 total fungal isolates obtained from wood samples, twelve genera and 
fourteen species were identified. The genus, Penicillium, had the most species that were identified and $P$. implicatum accounted for $29.7 \%$ of the total fungal isolates obtained. Bacillus sp predominated among the bacteria isolated from wood samples and accounted for nearly $42 \%$ of the total bacteria identified. Yeasts represented the lowest amount of the total population abundance ( $\log _{\mathrm{n}} \mathrm{CFU} / \mathrm{gram}$ ) and accounted for only $16 \%$ of the sampled community. Trichosporon cutaneum was the most frequently identified yeast, however, the genus Candida was represented by the most species and identification included $C$. sphaerica, C. kefyr, C. montana, C. steatolytica, C. humicola, and C. incommunis. The results of this study indicate that freshly sawn yellow-poplar lumber is immediately colonized by a variety of microorganisms and provide a baseline for characterizing the microbial ecology of freshly sawn hardwood lumber. 


\section{DEDICATION}

I dedicate this, my first work, to my parents without whom I would not have been able to excel at this level of scientific accomplishment. Their support has propelled me throughout my life, especially in the field of academics. Secondly, to my brother, who opened the door to a limitless abundance of opportunities that exist past the high school level. Thirdly, to my teachers, colleagues, co-workers, and friends for their undying support. 


\section{TABLE OF CONTENTS}

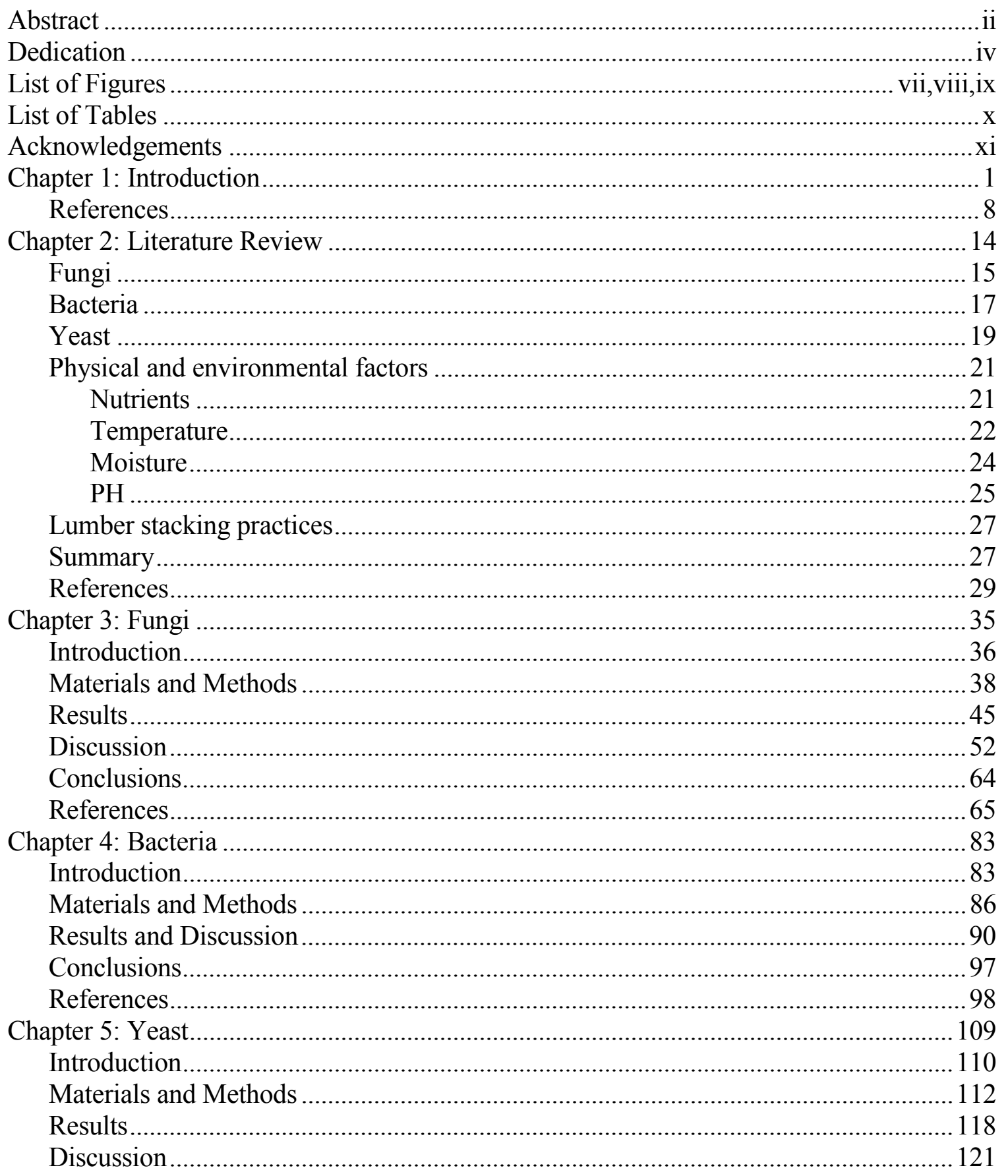




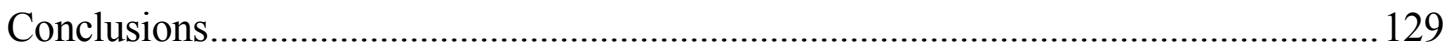

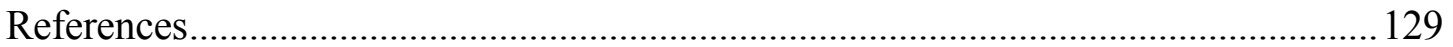

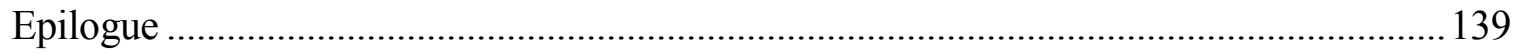




\section{LIST OF FIGURES}

Number

Page

Chapter 3

1. Cross-sectional view of dead-stacked yellow-poplar lumber 70

2. Diagram of cross-sectional view of dead-stacked lumber pile and designated sampling zone during spring of 2000 71

3. Diagram of cross-sectional view of dead-stacked lumber pile and designated sampling zone during summer of 2000 .71

4. Diagram of aerial view of sampling zones for microorganisms, $\mathrm{pH}$, and moisture content on designated lumber boards 72

5. Assembled view of modified boring bit designed for sampling microorganisms from wood .72

6. Disassembled view of boring bit used for sampling microorganisms from wood... 73

7. Comparison of average ambient temperature and temperature recorded in deadstacked lumber during spring and summer of 2000

8. Average moisture content of lumber boards in a dead-stack during spring and summer of 2000 74

9. Average moisture content of sticker-stacked lumber during storage in spring of 2000 74

10. $\mathrm{pH}$ of lumber boards processed and stored in a dead-stack in spring and summer of 2000 .75

11. Total and average abundance of fungi isolated from freshly sawn yellow-poplar lumber after various periods of storage during spring and summer of 2000 ....... 75

12. Percent of the total abundance of microorganisms isolated from freshly sawn yellow-poplar lumber stored in a dead-stack during spring and summer 2000 .......76 


\section{LIST OF FIGURES}

Number

Page

Chapter 4

1. Cross-sectional view of dead-stacked yellow-poplar lumber

103

2. Comparison of ambient and in-stack temperatures during spring and summer of 2000

3. Percent of microorganisms colonizing yellow-poplar lumber at various sampling periods in spring and summer of 2000 104

4. Comparison of bacterial abundance and average ambient temperatures between sampling periods in spring and summer of 2000 105

5. Percent of total bacteria identified from samples taken from green yellow-poplar lumber 


\section{LIST OF FIGURES}

Number

Page

Chapter 5

1. Increment borer used for taking moisture content and $\mathrm{pH}$ samples

135

2. Seasonal comparison of yeast abundance isolated from yellow-poplar lumber in

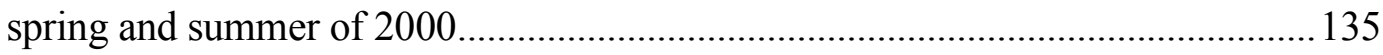

3. Percent of total abundance of microorganisms isolated from freshly sawn yellowpoplar lumber stored in a dead-stack during spring and summer of 2000 136

4. Comparison of yeast species isolated and identified from dead-stacked yellowpoplar lumber in spring and summer of 2000 136 


\section{LIST OF TABLES}

Number

Page

Chapter 3

1. Comparison of average ambient temperature and precipitation at Hart Field Airport (HFA) and West Virginia University Research Forest (WVURF) during spring of 2000 77

2. Climatological data recorded during spring of 2000 at HFA …............................... 78

3. Climatological data recorded during summer of 2000 at HFA ...............................78

4. Comparison of monthly average ambient temperatures at HFA and WVURF ......79

5. Fungal abundance per sampling period during spring and summer of 2000 ...........79

6. Fungi isolated and identified from yellow-poplar lumber during spring and summer

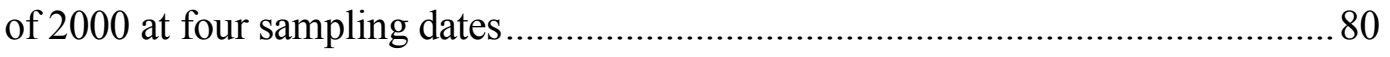

7. Percent of fungal isolates obtained after 60 days of storage during spring and summer of 2000 ..

81

8. Percent of fungal isolates obtained from yellow-poplar lumber on four sampling dates in spring and summer of 2000 82

Chapter 4

1. Bacterial abundance per sampling period during spring and summer of $2000 \ldots . . .106$

2. Characteristics of identified bacterial isolated from green yellow-poplar lumber in spring and summer of 2000 107

\section{Chapter 5}

1. Abundance of yeast isolated from yellow-poplar per sampling period during spring and summer of 2000 .

2. Succession of yeast isolated from dead-stacked yellow-poplar during spring and summer of 2000 . 


\section{ACKNOWLEDGMENTS}

The author wishes to express sincere appreciation to Dr. Daniel Panaccione and Mr. Mark Double for tireless efforts; Dr. William Thayne and Dr. Mark Brown for their assistance in the statistical analysis; Dr. Emilia Ricco, Dr. Tom Volk and Sean Westmoreland for the identification of fungi; Dr. Ellen Dickstein for the identification of bacteria; Dr. Robert Brooks and Dr. Ellen Dickstein for the identification of yeast colonies; Dr. Benjamin Dawson-Andoh, Dr. Woijiech Janisiewicz, Dr. William MacDonald, and Dr. James Armstrong for assisting me as part of my appointed committee; Mr. Jeffrey Slahor of Appalachian Hardwood Center, Division of Forestry, WVU; Mr. George Mikluscak for technical support; West Virginia University Forest Manager, Mr. Robert Driscole, for processing the lumber for this project, and $\mathrm{Mr}$. Michael Berakis for his overall assistance and expertise. 


\section{Chapter 1}

\section{INTRODUCTION}

Under appropriate conditions, wood is colonized by a diverse group of microorganisms, which include actinomycetes, bacteria, fungi, and yeasts. Potential infection sources or vectors for transport of such microorganisms include air, insects, ground contact, and water. Microbial colonization of wood results in its modification and deterioration. Two major types of wood deterioration are recognized from microbial colonization: discoloration and decay. Discoloration of green lumber is caused primarily by fungi. This discoloration is a resultant effect of darkly pigmented hyphae and spores produced by colonizing microfungi. Fungi responsible for this discoloration are normally classified as mold or sapstain fungi. Mold and sapstain discoloration of lumber is a major source of revenue loss each year to the forest products industry. This loss is incurred as a result of the reduction in market value of stained or discolored lumber (Morrell and Dawson-Andoh 1998). Wood discoloration caused by molds is restricted to the surface of lumber, however, sapstain fungi normally penetrate the surface of the lumber through wood elements, such as parenchyma cells, and therefore discoloration appears throughout logs and lumber. Although strength properties of discolored wood remain unaffected, colonization of wood by sapstain fungi usually results in an increased wood porosity and also an increased susceptibility to future colonization by other microflora. Discoloration of green lumber caused by the colonization of mold and sapstain fungi can be prevented by prompt air- or kiln-drying directly after lumber is processed (Scheffer and Lindgreen 1940). Drying lumber reduces the amount of available nutrients and lowers the wood moisture content below the optimum level required for growth by most fungi. Air-drying operations require a multitude of space and an extensive period of time. Kiln-drying facilities are expensive and require trained personnel to operate the kilns. Many sawmills lack the capital to implement a system of multiple processing and/ or drying lines. Therefore, freshly sawn lumber, which is susceptible to immediate infestation by stain- 
causing fungi, must remain dead-stacked for a variable period of time before drying. In most sawmills, green lumber is protected from mold and sapstain discoloration by the application of commercial biocides called anti-sapstain chemicals. Many currently available commercial anti-sapstain chemicals successfully control the growth and subsequent discoloration caused by mold and sapstain on green lumber. There is, however, an increasing public concern regarding the negative impact of such chemicals on humans, animals, plants, and the environment. This situation has lead to the search for an alternative form of control for those microorganisms that cause discoloration of lumber. One alternative to the application of anti-sapstain chemicals to control or prevent discoloration of lumber is biological control or bioprotection. Biological control strategies employ the use of microbial agents that are either competitive or antagonistic towards the target organisms, such as mold and sapstain fungi. Biologically based preservatives or biological control systems are looked upon more favorably by biocide registration agencies because they have less stringent requirements and tend to cost considerably less than chemical preservatives to bring to the market (Hall and Barry 1995). In addition, biological control agents (BCAs) persist less in the environment, are less toxic to non-target species, and are less likely to contaminate ground water when compared to effective chemical treatments. Technology also exists for a more practical disposal of BCAs (Hall and Barry 1995).

In relation to the wood industry, biological control has been defined as the use of biota to prevent or control wood biodeterioration. In the past, biological control exhibited some success in the field of agriculture, notably the control of post-harvest diseases of fruit and the control of pathogens on ornamental plants (Janisiewicz 1991; Wilson and Wisnieswski 1994). This success in the agricultural industry is demonstrated by the commercial availability of biological control products. Application of biological controls has been successful especially in situations where the potential infection site is precolonized by the biocontrol agent (Janisiewicz 1998). A classical example of this method of biocontrol was 
demonstrated by Risbeth (1963), who successfully used Phlebia gigantea to precolonize tree stumps to protect against infection by Heterbasidion annosus. The potential application of biological control agents to protect wood was given prominence by the work of Ricard and Bollen (1968). These investigators evaluated a Scytalidium sp (strain FY) for its ability to control decay caused by Antrodia carbonica in Douglas-fir utility poles. Since then, several research groups have evaluated the application of biological control agents for the protection of wood from deterioration (Bruce and King 1983, 1986; Bruce et al. 1984; Bruce and Highley 1990a, 1990b; Dawson-Andoh and Morrell 1997; Morrell and DawsonAndoh 1998; Croan and Highley 1991, 1992; Bernier et al. 1986; Benko 1986, 1987, 1988, 1989; Kreber and Morrell 1993). For example, Trichoderma sp has been evaluated for its ability to control wood decay caused by Serpula lacrymans (Doi and Yamada 1991, 1992; Score 1998; Score and Palfreyman 1994; Palfreyman 1995). Past research involving the biological control of wood biodeterioration has been characterized largely by some success in the laboratory and inconsistent performance in the field (Dawson-Andoh and Morrell 1997; Dawson-Andoh and Lovell 2000; Dawson-Andoh and Morrell 1992). Reasons advanced to explain the inconsistent results include the need to understand underlying mechanisms of control by biological control agents (BCAs) (Baker 1986), the need to develop more appropriate screening strategies of BCAs, and the need to isolate and identify biological control organisms that are ecologically adapted to their target environment (Deacon 1991). More importantly, perhaps, is the fact that potential biological control agents have been treated primarily in a chemical rather a biological paradigm. Sutton and Page (1993) stated that the treatment of biological control agents as biocides is reinforced by their mode of formulation and application, which is similar to that employed for chemical biocides. To date the majority of biological control studies have placed emphasis only on antibiotic production (by BCAs) as the primary mechanism of control of undesirable microorganisms (Fravel 1985). Natural products, such as antibiotics or secondary metabolites, extracted from microorganisms or plants and applied directly as biocides differ from those biologically active products produced in-situ by biological 
control organisms (Cook 1993). These differences may add to the inconsistencies observed between laboratory and field results as described earlier.

Antibiosis and competition are the two major mechanisms involved in biological control. The role of antibiosis, through the production of secondary metabolites, such as antibiotics and volatile organic compounds, has been extensively studied (Morrell and Dawson-Andoh 1998). As stated earlier, the majority of biological control studies have focused solely on the inhibition of growth of detrimental microflora through antibiosis. Evidence supporting the role of antibiosis on wood, however, has been at best indirect or circumspect and minimal success has been experienced in the field. Although antibiosis is an important aspect of biological control, Morrell and Dawson-Andoh (1998) stated that competition is generally considered to be the primary mechanism of biocontrol. Further, other mechanisms only provide a competitive edge to the antagonist (Deacon and Barry 1992; Lockwood and Filonow 1981). Competition, in relation to biological control, involves the selective utilization of nutrient components of a substrate by BCAs. For example, DawsonAndoh and Lovell (2000) demonstrated that Gliocladium virens, a potential biological control agent, selectively used amino acids for the germination of its spores. Similar studies involving the use of bacteria as BCAs reported that selective utilization of amino acids by Pseudomonas sp occurred during its inhibition of germination of Botrytis cinera conidia (Blakeman and Brodie 1977; Brodie and Blakeman 1975; Dik 1991). In addition to amino acids, selective usage of nutrients on wood by BCAs during competition also may include simple carbohydrates, lipids, resin acids, and proteins as a source of carbon or nitrogen.

The success and commercial availability of biological control agents in the agricultural industry has been reviewed. Success of these BCAs has been achieved through precolonization of the potential infection sites and is an indication of the importance of understanding the ecology and the ecological competence of the biological control agents 
in the ecosystem for which they were designed. BCAs are living organisms whose propagules must germinate or grow to enable them to exert their effect. Simply stated, biological control agents must be ecologically fit or competent for their target niche (Janisiewicz 1998). The interaction of BCAs and other microflora is mediated by physical factors, such as $\mathrm{pH}$, nutrients, temperature, and moisture. Past studies of biological controls used to inhibit wood biodeterioration and degradation have focused on the use of various in-vitro techniques to screen for potential biological control agents. Such studies have involved the use of mainly synthetic medias and have been performed in a laboratory or controlled setting. These artificial conditions seldom represent or reflect the complex nature of a substrate such as wood. Although results of such laboratory studies appear promising in some situations, similar successes have been unable to be duplicated under field conditions. Other studies have focused on the concept of the "silver bullet"contol agent. The basis of such studies involves the concept of using a single microorganism to control the growth of microflora responsible for the deterioration of wood. Microorganisms with such a broad-spectrum capability have not been identified. A mixture of microorganisms might ensure far more consistent results (Janisiewicz 1998; Cook 1991). Little attention has been paid to the study of the ecology of introduced biological control agents (autecology) or the microbial community structure (synecology) and factors that impact their (BCAs) development (Janisiewicz 1998). These factors have been addressed and as previously mentioned such an approach has been used with considerable success in the control of post-harvest diseases of fruits, vegetables, and flowers in the field of agriculture (Janisiewicz 1988, 1994, 1996; Janisiewicz et al. 1992; Janisiewicz and Bors 1995; Lindow 1991, 1994; Wilson and Lindow 1994). This approach, which first focuses on studying the microbial ecology of the target substrate, allows the identification of BCAs that were isolated from and therefore ecologically fit to that niche. Perhaps, by following similar methodology and initially studying the ecology of the microflora that exist on wood (lumber) during different seasons, enough information 
may be obtained on the composition, identity, succession, and interaction of the microbial community to enable the manipulation of the conditions on wood to favor that of BCAs.

Past studies involving the microbial ecology of wood have focused mainly on softwood (gymnosperms) species. In Canada, for example, fungi causing mold/sapstain of freshly sawn lumber have been studied on commercially important softwood species such as Abies balsamea, Picea mariana, P. glauca, Pinus contorta, and P. banksiana (Seifert and Grylls 1992; Uzonovic et al. 1999). Ophiostoma piceae was identified as the most commonly isolated species (Uzonovic et al. 1999). Other fungi reported include the genera Aureobasidium and Phacidium (Uzonovic et al. 1999). Smith et al. (1970) and Morrell et al. (1987) also studied the microbial ecology of fungi on Douglas-fir utility poles with emphasis on the changes in their composition from time of manufacture to the period of wood deterioration. One of the most recent studies of fungal colonization of wood was performed by Kang and Morrell (2000). These authors reported the fungi isolated from Douglas-fir sapwood lumber in Oregon. The occurrence of yeasts and bacteria were not reported in any of the studies listed above.

Bacteria and yeasts have been reported to colonize wood. Several past studies have indicated that early colonizers of stored lumber include fungi, bacteria, and yeast-like fungi, however, few studies have reported on the entire microbial ecology of wood (Liese and Karnop 1968; Greaves 1971; Rossell et al. 1973; Greaves and Levy 1968; Kaarik 1975; Levy 1975; Knuth and McCoy 1962; Shigo 1965, 1966). Greaves (1972) reported on the microbial ecology of CCA-treated and untreated softwood stakes, but focused on the exposure of these stakes to tropical soils. A similar study involving the microbial ecology of wood was performed by Dutkiewicz et al. (1992). Although this study involved the microbial ecology of several wood species, focus was placed on the endotoxins produced by isolated microorganism and the evaluation of a sampling device designed to quantify microorganisms on wood. An apparent need still exists for a study that reports on the 
entire microbial ecology of wood. This need is especially evident for the development of ecologically based biological control system which is to be established on the knowledge of naturally existing microflora obtained from such studies.

The primary objective of this work was to study the microbial ecology of freshly sawn (green) hardwood lumber during spring and summer of 2000 with specific focus on three groups within the microbial community. The three groups of microorganisms, namely, fungi, bacteria, and yeasts were isolated from samples and identified in this study. Yellow-poplar (Liriodendron tulipifera L.), a hardwood species of local and eastern regional economic importance, was chosen as the model hardwood species for this study. 


\section{REFERENCES}

BAKER, R. 1986. Biological control: An overview. Can. J. Plant Pathol. 8: 218-221.

BENKO, R. 1986. Protection of wood against the blue stain. Int. Cong. of IUFRO. Reference \# 18. Ljubljana. Yugoslavia.

----------. 1987. Antagonistic effects of some mycorrhizal fungi as biological control of bluestain. Int. Res. Group on Wood Preserv. Stockholm, Sweden. IRG/WP/1314.

1988. Bacteria as possible organisms for biological control of blue-stain. Int. Res. Group on Wood Preserv. Stockholm, Sweden. IRG/WP/1339.

----------. 1989. Bacterial control of blue-stain on wood with Pseudomonas cepacia 6253. laboratory and field test. Int. Res. Group. Stockholm, Sweden. IRG/WP/1380.

Bernier, R., J. M. Desrochers, AND L. JURASEK. 1986. Antagonistic effect between Bacillus subtilis and wood staining fungi. J. Inst. Wood Sci. 10(5): 214-216.

Blakeman, J. P., AND I. D. S. Brodie. 1977. Competition for nutrients between epiphytic microorganisms and germination of spores of plant pathogens on beetroot leaves. Physiol. Plant. Pathol. 10: 29.

Brodie, I. D. S., AND J. P. Blakeman. 1975. Competition for carbon compounds by a leaf surface bacterium and conidia of Botrytis cinera. Physiol. Pathol. 6: 125.

BRUCE, A., AND B. KING. 1983. Biological control of wood decay by Lentinus lepideus (Fr.) produced by Scytalidium and Trichoderma residues. Mater. Orgon. 18: 171-181.

-----------., AND -----------. 1986. Biological control of decay in creosote treated distribution poles. 2. Establishment of immunizing commensal fungi in poles. Mater. Orgon. 21: 1-13.

--------., AND T. L. Highly. 1990A. Biological control of decay in creosote treated distribution poles. 3. Control of decay in poles by immunizing commensal fungi after extended incubation period. Mater. Orgon. 25:15-28.

---------., AND T. L. Highly. 1990B. Decay resistance of wood removed from poles biologically treated with Trichoderma spp. Holzforschung. 45 (4): 307-311.

---------., W. J. AUSTIN, AND B. KING. 1984. Control of growth of Lentinus lepideus by volatiles from Trichoderma. Trans. Brit. Mycol. Soc. 82: 423-428. 
CoOK, J. R. 1991. Biological control of plant diseases: broad concepts and applications. Page 1 in J. Bay-Petersen, eds. The Biological control of Plant Diseases. FFTC Book series \# 42. Food and Fertilizer Technology Center for Asian and Pacific Region. Taipei, Taiwan. 1993. Making greater use of introduced microorganisms for biological control of plant pathogens. Ann. Rev. Phytopathol. 31: 53.

Croan, S. C., AND T. L. Highly. 1991. Control of sapwood-inhabiting fungi by fractionated extracellular metabolites from Coniophora puteana. Int. Res. Group Wood Preserv. Stockholm, Sweden. IRG/WP/1494.

----------., and ----------. 1992. Biological control of sapwood inhabiting fungi by living bacterial cells of Streptomyces rimosus as a bioprotectant. Int. Res. Group Wood Preserv. Stockholm, Sweden. IRG/WP/1564-1592.

DAWSON-ANDOH, B. E., AND J. J. MORRELL. 1992A. Enhancing the performance of bioprotection agents by pretreatment with waterborne salts. Wood Fiber Sci. 24(3): 347352.

---------., AND ----------. 1997. Biological protection of freshly sawn sapwood from biological discoloration. Pages 3-9 in Prevention of discoloration in hardwoods and softwood logs and lumber. For Prod. Soc. Publications.

---------., AND R. LOVELL. 2000. Effect of nutrients on spore germination of Gliocladium roseum and Ophiostoma piceae. Wood Fiber Sci. 32(1): 116-124.

DeACON, J. W. 1991. Significance of ecology in the development of biological control agents against soil-borne plant pathogens. Biol. Sci. Technol. 1: 5-20

---------., AND L. A. BARRY. 1992. Modes of action of mycoparasites in relation to biocontrol of soilborne pathogens. Page 157 in E. C. Tjamos, G. C. Papvizas and R. J. Cook, eds. Biological control of plant diseases. NATO ASI Series A: Life Sciences. Volume 230. Plenum Press. New York.

DIK, A. D. 1991. Interactions among fungicides, pathogens, yeast, and nutrients in phyllosphere. Page 412 in J. H. Andrews and S. S. Hirano, eds. Microbial Ecology of Leaves. Springer-Verlag. New York. 
Dutkiewicz, J., C. Kwapiszewski, S. Olenchock, And D. Lewis. 1992. Compact drill sampler for the quantitation of microorganisms in wood. United States Patent: 50378553.

Fravel, D. R. 1985. Role of antibiosis in the biocontrol of plant disease. Ann. Rev. Phytopathol. 26: 75-91.

Garraway, M. O., AND Evans, R.C. 1984. Nutrition as a basis for the study of fungi. Fungal Nutrition. New York. John Wiley and Sons, Inc. 1-3, 20.

GreAves, H. 1971. The bacterial factor in wood decay. Wood Sci. Technol. 5:6-16.

---------. 1972. Microbial ecology of untreated and copper-chrome-arsenic treated stakes exposed in a tropical soil. The initial invaders. Can. J. Microbiol. 18(12): 1923-1931.

., AND J. F. LEVY. 1968. Microbial associations in the deterioration of wood under long-term exposure. Pages 429-443 in A. H. Walters and J.J Elphick, eds. Biodeterioration of materials. Microbiological and applied aspects. Elsevier, Amsterdam.

HALl, F. R., AND J. W. BARRY. 1995. An overview of biorational pest control agents. Pages 118 in F. R. Hall and J. W. Barry, eds. Biorational pest control agents. Formulation and delivery. ACS symposium series 595.

JANISIEWICZ, W. J. 1988. Biocontrol of postharvest diseases of apples with antagonistic mixtures. Phytopathology 78: 194-198.

--------- 1991. Biological control of postharvest fruit diseases. Page 301 in D. I. Arora, B. Rai, K. G. Mukerji and G. K. Knudson, eds. Handbook of applied mycology. Marcel Dekker, Inc. New York.

---------. 1994. Nutritional characterization of natural microflora of apple and its possible role in selection of biocontrol agents. Phytopathology 84: 1152.

--------- 1996. Ecological diversity, niche overlap, and coexistence of antagonists used in developing mixtures for biological of postharvest diseases of apples. Phytopathology 86: 473.

1998. Biocontrol of postharvest diseases of apples with antagonistic mixtures. Phytopathology 78: 194-198. 
AND B. BORS. 1995. Development of a microbial community of bacterial and yeast antagonist to control wound-invading post-harvest pathogens to fruits. Appl. Environ. Microbiol. 61(9): 3261-3267.

., AND J. RothMAN. 1998. Biological control of blue mold and grey mold on apple and pear with Pseudomonas cepecia. Phytopathology 78: 1697-1700.

---------., J. USALL, AND B. BORS. 1992. Nutritional enhancement of biocontrol of blue mold on apples. Phytopathology 82: 1364.

KAARIK, A. 1975. Succession of microorganisms during wood decay. Pages 39-51 in W. Liese, eds. Biological transformation of wood by microorganisms. Springer. Berlin.

KANG, S., AND J. J. MORRELL. 2000. Fungal colonization of Douglas-fir sapwood lumber. Mycologia. 92(4):609-615.

KreBer, B., AND J. J. MORRELl. 1993. Ability of selected bacteria and fungal bioprotectants to limit fungal stain in ponderosa pine sapwood. Wood Fiber Sci. 25(1): 23-34.

KNUTH, D. T. AND E. MCCOY. 1962. Bacterial deterioration of pine logs in pond storage. Forest Prod. J. 12(9): 437-442.

LEVY, J. F. 1975. Colonization of wood by fungi. Pages 16-23 in W. Liese, ed. Biological transformation of wood by microorganisms. Springer, Berlin.

LIESE, W., AND G. KARNOP. 1968. On the attack of coniferous wood by bacteria. Holtz RohWerkstoff 26: 202-208.

LinDOW, S. E. 1991. Determinants of epiphytic fitness in bacteria. Page 295 in J. H. Andrews and S. S. Hirano, eds. Microbial ecology of leaves. Springer-Verlag. New York.

--------. 1994. Epiphytic fitness determinants in bacteria. Page 29 in D. D. Bills and S. D. Kung, eds. Proceedings of the fourth international symposium, biotechnology and plant protection. World Scientific Publishing Co. Pte. Ltd. Singapore. River Edge, New Jersey.

Lockwood, J. L., AND A. B. FILONOV. 1981. Responses of fungi to nutrient-limiting conditions and to inhibitory substances in natural habitats. Adv. Microbiol. Ecol. 5:1. 
Morrell, J.J., M.E. Corden, R.D. Graham, B.R. Kropp, P. Przybylowicz, S.M. Smith, AND C. M. SEXTON. 1987. Basidiomycete colonization of air-seasoned Douglas-fir poles. Proc. Am. Wood-Preserv. Assoc. 83:284-294.

, AND B. E. DAWSON-ANDOH. 1998. Biological control: panacea or boondgle. Pages 39-44 in Biology and prevention of sapstain. A conference sponsored by the Department of Forest Products, Oregon State University. Delta Whistler Resort. British Columbia. Canada.

RiCARD, J., AND W. B. Bollen. 1968. Inhibition of Poria carbonica by Scytalidium sp.: an important fungus isolated from Douglas-fir poles. Can. J. Bot. 46: 643-647.

RisBeTH, J. 1963. Stump protection against Fomes annosus. III. Inoculation with Peniophora gigantea. J. Appl. Biol. 52: 63.

Rossell, S. E., E. G. M. AвBot, And J. F.Levy. 1973. Bacteria and wood. A review of the literature relating to the presence, action, and interaction of bacteria in wood. J. Inst. Wood. Sci., 6: 28-35.

SChefFER, T. C., AND R. M. LindGREEN. 1940. Stains of sapwood products and their control. USDA. Washington, D. C. Techn. Bull. 714. 122pp.

ShigO, A. L. 1966A. Organism interaction in decay and discoloration in beech, birch, and maple. US Forest Service Research Paper, NE-43.

---------. 1966B. Decay and discoloration following logging wounds on the northern hardwoods. US Forest Service Research Paper, NE-47.

---------. 1965. Decay and discoloration following logging wounds on the northern hardwoods. US Forest Service Research Paper, NE-47.

SiefERT, K.A. AND B.T. Grylls 1992. A survey of sapstaining fungi of Canada. Ottawa: Forintek Canada Corp. 31pp.

Smith, R.B., H.M. Craig, AND D. Chu. 1970. Fungal deterioration of second growth Douglas-fir logs in coastal British Columbia. Can. J. Bot. 48:1541-1551. 
Uzonovic, A., D-Q. Yang, P. Gagne, C. Breuil, L. Bernier, A. Bryne, M. Gignac, And S. H. KIM. 1999. Fungi that cause sapstain in Canadian softwoods. Can. J. Microbiol. 45(1): 914-922.

WILSON, C. L., AND M. E. WisNiEWISKI (EDS). 1994. Biological control of postharvest diseases: theory and practice. CRC Press. Boca Raton. FL.

WILSON, M., AND S. E. LINDOW. 1994. Ecological similarity and coexistence of epiphytic icenucleating Pseudomonas syringae strains and nonice-nucleating biological control agent. Appl. Environ. Microbiol. 60: 3128. 


\section{Chapter 2}

\section{LITERATURE REVIEW}

Brock (1987) generically defined ecology as the study of organisms within their environment. Proper ecological studies should, therefore, evaluate the general relationships between the organisms and their environment in terms of population, location, and activity (Pickup and Saunders 1996). Pickup and Saunders (1996) stated that studies evaluating the microbial ecology also should include an examination of influential biotic and abiotic factors on colonizing microorganisms. Biotic factors include the dynamics of an anthropogenic and non-anthropogenic nature and normally refer to microorganisms, insects, and animals. Abiotic factors include both physical and chemical factors. Examples of physical factors are temperature, relative humidity, UV radiation, water activity (precipitation), and wind. Chemical factors include nutrients and the chemical composition of the substrate. In a study that focuses on wood, for example, the chemical composition includes both extractable (extractives) and non-extractable chemical components. The latter refers to cellulose, lignin, and hemicellulose. Extractives are chemical components that can be removed from wood with water or organic solvents. Extractives give wood its characteristic color and odor. Extractives also are responsible for the natural durability of wood. Additional chemicals, such as chemical biocides, which exist in the system that also affect the ecology of colonizing microorganism should be included in the study of microbial ecology.

\section{Fungi}

Fungi are distinct in their mode of nutrition and this is reflected in the habitats they occupy. These microorganisms lack chlorophyll and are heterotrophic (Garaway and Evans 1984). Fungi mainly function as saprophytes and obtain their food through the extracellular 
digestion of a non-living substrate and the absorption of the resultant nutrients. In particular, each individual species may be selective in their nutritional requirements and therefore colonize only specific substrates (Garaway and Evans 1984).

Fungal colonization of wood may occur through either primary or secondary resource capture. Primary resource capture occurs when a virgin substrate is colonized by fungi. Colonization of such fungi is effected primarily by the activity of extracellular enzymes (Zabel 1953). These enzymes enable the fungi to utilize nutrients that are of low molecular weight and easy to metabolize, such as simple carbons available in the wood tissue (Zabel 1953). Primary colonizing fungi are good competitors that are characterized by fast growth and short life cycles (Deacon 1997). These fungi have a short exploitative phase quickly followed by the production of asexual dispersal spores or sexual resting spores. Typically, pioneer fungi are intolerant of antibiotics, metabolites, and environmental stress $(\mathrm{pH}$, temperature, etc.), which render them unable to defend a resource against invaders (Deacon 1997). Further, pioneer fungi are generally unable to produce antibiotics themselves, which increases their vulnerability to other colonizing microorganisms (Deacon 1997). Examples of pioneer colonizers can be found among the major classes of fungi and include Ascomycetes, Basidiomycetes, Deuteromycetes, and Zygomycetes.

Fungi also function as secondary colonizers. Secondary colonization or secondary resource capture involves the infection of a pre-occupied substrate (Zabel 1953). Fungi that exhibit secondary resource capture capabilities are generally antagonistic to existing microflora (Zabel 1953). Such antagonism can result from the production of secondary metabolites, which inhibit the growth of certain other microorganisms. Fungi involved in secondary resource capture are normally more diverse in nature than primary colonizers. For example, fungi such as Basidiomycetes have the ability to depolymerize and use complex wood components as a source of nutrition. These complex wood components include both polysaccharide and lignin constituents of wood cells. Numerous Basidiomycetes function as decay or wood rotting fungi. Decay fungi include both brown-rot and white-rot fungi, each of which degrades wood tissues in a different manner. Individual species of fungi 
affect a substrate, such as wood, and cohabitating resident microflora in a variety of ways. The interaction or competition between these microorganisms, as well as the available nutrients, may be an important clue in determining their distribution, growth patterns, and ecological roles within wood tissues (Rayner and Todd 1979).

Mold and sapstain causing fungi that frequently are isolated from both logs and lumber have been identified as Deuteromycetes and Ascomycetes (Scheffer and Lindgren 1940). The notable genera of stain causing fungi among the Deuteromycetes include Diplodia, Cladosporium, Hormodendron, and Graphium. Differences do exist in the fungal species that occur on hardwoods and softwoods. In the southern US, while Endoconiophora coerulescens Munch., E. moniliformis, Ceratostomella pluriannulata Hedge., and Graphium rigidum (Pers.) Sacc. commonly occur as mold and sapstain fungi on hardwoods, C. ips Rumbold, C. pilifera (Fr.) Winter, and Diplodia sp dominate as mold and stainers on softwoods such as pines (Davidson 1935). Common to both hardwoods and softwoods is D. natalensis P. Evans. Several other fungi also cause the discoloration of wood. For example, many species of Fusarium and Penicillium have been reported to be responsible for the bright colored sapstains found in wood (Scheffer and Lindgren 1940).

Studies in separate geographical regions in Canada indicate that the Ophiostoma was the most dominant staining genus on five important commercial softwood species, Abies balsamea (1) Mill., Picea mariana (Mill.) B.S.P., P. glauca (Moench) Voss, Pinus contorta Dougl. and P. Banksiana Lamb (Uzonovic et al. 1999). These studies did not indicate any evidence of exclusion in the occurrence of specific fungi from different geographical zones or the different wood species studied. In total, nine species of Ophiostoma were isolated from on all species of lumber at each geographical location and represented $97 \%$ all fungi obtained (Uzonovic et al. 1999). Ceratocystis adiposa, O. piceae, and O. piliferum were responsible for most of the sapstain on lumber. Aureobasidium pullulans, C. coerulescens, O. ips, O. minus, and P. coniferarum, were rarely isolated from lumber although they were commonly observed in stained logs. Recently, fungi colonizing green Pseudotsuga menziesii (Douglas-fir) sapwood lumber have been evaluated (Kang and Morrell 2000). 
From 547 total fungal isolates, 29 genera and 45 species were identified. Graphium sp constituted $17 \%$ of all isolates. Other fungal species occurring in high frequency included Trichoderma viride, T. harzianum, T. koningii, Mucor sp, Penicillium para-herquei, P. purpurogenum, Scytalidium lignicola, and Sporothrix sp (Kang and Morrell 2000).

True and Tyron (1966) studied the fungal colonization of yellow-poplar stumps. During their study, it was reported that different fungi occurred at different depths. Surface colonizing fungi that caused stain included the genera Aspergillus, Fusarium, Coniothyrium, Gloeosporium, Penicillium, and Trichoderma. Fungi causing decay occurred deep in the stump and included Peniphora sp, Polyporus adustus, Polyporus versicolor, Pleurotus ostreatus, and Stereum purpueum.

\section{Bacteria}

Most of the studies concerning microbial ecology of wood have been one dimensional with focus only on fungi, however, many reports have documented the colonization of wood by other microorganisms, namely bacteria (Liese and Karnop 1968; Greaves 1971; Rossell et al. 1973; Greaves and Levy 1968; Kaarik 1975; Levy 1975; Shigo 1965, 1966 McCreary et al. 1965; Ellwood and Ecklund 1959; Knuth 1964; Greaves 1965; Knuth and McCoy 1962). In wood, bacteria tend to colonize in rays, resins ducts, and pits (Highley and Lutz 1970). Bacteria are ubiquitous in nature and have been associated with wood in ground contact, stored in water, in water cooling towers, chip piles, and living trees (Rossell et al. 1973; Shigo 1965). In ground contact, colonization of wood by fungi is preceded by bacteria (Etheridge 1961). In logs, bacteria may be associated with and actually enhance the activities of wood decay fungi through the production of metabolites, such as thiamine, which functions as a growth factor (Henningsson 1967). This author also reported that in preservative treated wood, bacteria may enhance the decay activity of fungi through its detoxification of the preservative. Reports indicate that bacteria also have been associated synergistically with fungi, specifically Deuteromycetes, in discolored and decayed regions

of trees (Maloy and Robinson 1968). Greaves and Levy (1968) observed the destruction of secondary cell walls, fibers, and tracheids through the synergistic interaction of bacteria 
and soft-rot fungi. Bacteria also may be antagonistic to microbiota colonizing wood. Reports of Jacquoit (1962) and Jacquoit and Lapetite (1967) indicate that this antagonistic relationship is demonstrated by the inhibition of wood decay fungi by bacteria. Rossell et al. (1973) stated that nutrition is an important mediator between the types of bacterialfungal interaction. These authors reported that synergistic interaction with fungi may occurs at the end of bacterial succession and antagonistic interaction may occur at the beginning of bacterial succession (Rossell et al. 1973).

Several bacterial species have been isolated from wood. However, the genus Bacillus represents the majority of bacteria frequently isolated from wood and include $B$. asterosporus, B. cereus, B. megaterium, B cereus var mycoides, B macerans, B. subtilis, B. pumulus, and B. polymyxa (McCreary et al. 1965; Ellwood and Ecklund 1959; Knuth 1964; Greaves 1965; Knuth and McCoy 1962). Other bacteria isolated from wood include Clostridium omelianski, Sarcinia sp, Micrococcus sp, Staphytococcus sp, Desulphovibrio desulphuricans, Xanthomanas sp, Serratia sp, Flavobacterium sp, Pseudomonas sp, Cellulomonas sp, Aerobacter aerogenes, and A. cloacae (Liese and Karnop 1968; Ellwood and Ecklund 1959; Lutz et al. 1966; Knuth 1964; Knuth and McCoy 1962; Greaves 1971; McCreary et al. 1965; Kelman and Cowling 1965; Freeman et al. 1948).

Bacteria have been evaluated as potential biological control agents against wood decay, mold, and sapstain fungi (Seifert et al. 1987; Benko 1986, 1987, 1988, 1989; Benko and Highley 1990a, 1990b; Payne et al. 2000). Bacillus, Streptomyces, and Pseudomonas represent the genera most frequently screened for biological control activity against fungi colonizing wood. These bacteria were selected based on the results of studies that indicated success in the biological control or protection of various plants (Dawson-Andoh and Morrell 1997).

\section{Yeast}

Yeasts have been reported to colonize wood in association with both bacteria and fungi (Sorenson et al. 1991). Although yeast has been defined as a fungus whose dominant form 
of growth is unicellular, fungi and yeasts are normally classified separately due to the differences in growth characteristics. As with all microorganisms, colonization by yeasts is variable depending on several influential factors. Sorensen et al. (1991) reported that levels of yeast varied with seasons, wood species, and gross anatomy type (sapwood, heartwood, bark). Each of these factors appears to influence the concentration of yeasts. For example, Sorenson et al. (1991) reported that the highest concentration of yeasts occurred in late spring. Other studies have indicated that concentration of yeasts is highest during the early phase of wood colonization, regardless of season (Shigo and Hills 1973; Kaarik 1975). In a study that examined microorganisms that colonized logs of basswood, black cherry, black locust, red oak, soft maple, and white poplar, the highest levels of yeasts were commonly isolated from the sapwood (Sorenson et al 1991).

Several species of yeasts have been isolated and identified from wood samples. From a study performed on six different wood species by Sorenson et al (1991) described above, identification included Aureobasidium pullulans, Cryptococcus sp, Candida sp, Pichia (Hansenula) sp, and Rhodotorula sp. From the genus Rhodotorula, Rh. glutinis was the most commonly isolated species, but identification also included Rh. rubra and Rh. minuta. Candida sake was the most commonly isolated species of the genus Candida. Other identified species included C. freyschussii, C. maritima, C. zeylanoides, C. edax, C. famata, C. scottii, and C. tenuis. Three species of Pichia were identified including P. fabianii, $P$. silvicola, and $P$. tanii.

Yeasts interact in a variety of relationships with microorganisms colonizing the same substrate. For example, Chalutz (1990) demonstrated that the yeast Debaryomyces hansenii inhibited the growth of green and blue mold. Payne et al.(2000) established that yeast also possess the ability to reduce the growth of certain wood decay Basidiomycetes, molds, and stain fungi under laboratory conditions. Conversely, Shigo (1965) reported that certain yeast actually enhance the production of pigments by fungi and stimulate growth. 
Yeasts impact both the composition and the colonization pattern of microflora on a particular substrate during their growth. This transpires through activities such as nutrient utilization and production of secondary metabolites. Production of pigments, volatile organic compounds, and other secondary metabolites by yeasts has been reported (Shigo 1965; Payne et al. 2000; Walker and McCleod 1995). These organic compounds are of particular interest in the formulation of biologically based preservative because yeast species that produce such compounds may be investigated for their ability to function as biocontrol agents. Walker and McLeod (1995) indicated the potential of yeast to function as biological control agents by measuring their ability to inhibit the growth of wood decay and stain fungi under laboratory conditions. From the results obtained in their study, these authors concluded that inhibition was due to the production of a proteinaceous "killer" toxin produced by yeast (Walker and McLeod 1995). Similar studies have been performed to evaluate the ability of yeasts to function as biological control agents against fungi under laboratory conditions (Payne and Bruce 1999; Payne et al. 2000). Results of these studies varied depending on type of substrate used. Growth of sapstain fungi was either inhibited, reduced, or its pigmentation was reduced by yeasts in vitro. Successful inhibition was ascribed to the volatile organic compounds (VOCs) produced by those yeasts used in these studies. The agricultural industry experienced similar successes with the use of yeasts as a biological control agents (Chalutz 1990; Wisniewski et al. 1991; Mercier and Wilson 1994; Filonow et al. 1996). These researchers successfully integrated the use of biological control agents to control of post-harvest diseases of fruits, vegetables, and flowers (Janisiewicz 1988, 1994, 1996; Janisiewicz et al. 1992; Janisiewicz and Bors 1995; Lindow 1991, 1994; Wilson and Lindow 1994). The use of microorganisms, such as yeast, as a biological control agent is a practical alternative to chemical preservatives because of their ease of maintenance, non-demanding environmental and nutritional requirements, harmlessness to humans and the environment, accompanied by their wide distribution in nature (Payne et al. 2000). 


\section{Physical and Environmental Factors}

Many physical and environmental variables exist which influence the colonization of microorganisms on wood surfaces. These factors should be investigated or at least considered when investigating the microbial ecology of wood. Dawson-Andoh and Morrell (1997) stated that the lignoplane is a diverse environment with cyclic and noncyclic environmental variables including temperature, relative humidity, dew, rain, wind, and radiation. Scheffer and Lindgren (1932) who studied the seasonal effects on microbial colonization, reported that microbial development and growth was dependent on abiotic (environmental) factors such as temperature, relative humidity, and precipitation especially in relation to mold and sapstain fungi. Similar observation were made by Pickup and Saunders (1996), who stated that physical factors such as $\mathrm{pH}$, nutrients, and moisture influence the population of microorganisms as well as the substrate they are colonizing. In the investigation of the microbial ecology of wood, other factors that should not be overlooked include wood species, the amount of sapwood present in the wood samples, and the length of exposure to the factors listed above. Collectively, these factors are an important key to determining the reason for the existence of specific microorganisms in a mixed population at any particular time.

\section{Nutrients}

Arguably, the most important or major limiting factor for microbial activity is the amount and type of available nutrients. For example, Dawson and Lovell (2000) reported that in relation to colonization of fungi, spore germination is influenced directly by specific nutrient availability. Most microbial species are different in their nutritional requirements and some are so selective that they will grow only on specific substrates (Garraway and Evans 1984). Nutrients are obtained in several ways by microorganisms. Microorganisms can exist both parasitically or saprophytically in association with trees. Parasites grow on and acquire the necessary nutrition from living organisms. On wood, most microorganisms are saprophytic and obtain their nutrients from non-living material (Deacon 1997). Saprophytes play a major role in the decomposition of dead organic matter and the recycling of nutrients in nature (Deacon 1997). Saprophytic microorganisms, which 
include fungi and certain bacteria, have the ability to break down the structural elements of wood, such as cellulose and lignin. Conversely, microorganisms that lack the necessary enzymes for degrading wood elements must utilize the readily available nutrients that exist after processing or following the breakdown of wood elements by another resident microbe. As discussed in relation to fungi, alteration of the nutrient composition of wood may open the door for pioneer fungi or microorganisms that would not naturally exist. A case in point is the study of Last and Price (1969) who reported that colonization by some microorganisms may depend on earlier activity of bacteria that make essential nutrients available. Several nutrients that exist on or in wood include: carbohydrates, amino acids, sugar alcohols, mineral trace elements, vitamins, and hormones (Bamber and Humphrey 1964). Sapwood, however, is normally richer in food reserves than the heartwood. In wood, notably hardwoods, starch is normally the most abundant storage component. Starches and proteins are abundantly stored in parenchyma cells. The amount of stored nutrients in wood varies with respect to season. The amount of starch is lowest during the spring due to the need for growth by trees themselves. During summer and fall months the growth rate of trees is slowed and the highest amounts of stored starches can be found in wood. Trees that are sawn in to logs also vary in the amount of nutrients stored in wood elements in different seasons. Dowding (1970) demonstrated that logs stored during winter lose soluble nutrients less rapidly than those stored in summer. Generally stated the amount of available nutrients in wood varies with the wood species, age, season it was felled, light, temperature, $\mathrm{pH}$, and extent of injury to the tree.

\section{Temperature}

Temperature is important to the growth of microorganisms. Several studies have indicated that the appearance, interaction, and distribution of microorganisms that colonize wood are influenced and/ or largely determined by temperature (Shields 1969; Humphrey and Sigger 1933; Henningsson 1967). Therefore, differences in temperature due to seasonal effects or geographic location, will influence the composition and distribution of the certain species in the microbial community. A case in point is the colonization of the fungus Serpula lacrymans, which has a low maximum temperature and does not exist in regions of the 
world with high summer temperatures (Rayner and Todd 1979). Most bacteria and fungi find their optimum growth temperature between $25-35^{\circ} \mathrm{C}$, but this may be dependent on the species. Butcher (1968), while investigating the ecology of fungi occurring on Pinus radiata, observed that the optimum temperature for the growth of most fungi was $25^{\circ} \mathrm{C}$. Several exceptions were noted during this investigation. For example, Chaetomium sp, Cephalosporium sp, and Paecilomyces sp had an optimum temperature of $25-30^{\circ} \mathrm{C}$ for growth. Botrytis sp, Moeszia sp, Alternaria sp, Cladosporium sp, and Hormiscium sp grew best between 20 and $25^{\circ} \mathrm{C}$. A study performed at the USDA Forest Products Laboratory in Madison, Wisconsin showed that the initial increase in the natural fungal flora (yeasts and filamentous fungi) took place slowly over six days at $18^{\circ} \mathrm{C}$ but even slower, requiring 20 days, at $4{ }^{\circ} \mathrm{C}$ (Mercier and Wilson 1994). Similar colonization rates were demonstrated by yeast during the investigation of stored wood. Sorenson et al. (1991) determined that colony counts for samples collected in August and May were 100-fold higher than samples collected in October and February. This observation suggests that samples taken during months of lower average temperature may result in suppression of the growth of yeast (Sorenson et al. 1991). Based on the results of their investigation, Sorenson et al. (1991) concluded that yeasts were significantly higher during the months of late spring and summer.

During the investigation of freshly bared sapwood surfaces, Dowding (1970) observed that the greatest number of fungi occurred from June to September and the lowest number of fungi from winter to early spring. However, in relation to specific groups of fungi Dowding (1970) reported that although the frequency of many saprophytes varied predominantly with time of year, Basidiomycetes displayed maximum growth activity during the months of July and February. Dowding (1970) further stated that Sapstain fungi, Ceratocystis sp in particular, were at peak activity in the late summer. Although no seasonal variation was displayed by certain species of Ceratocystis, Fusarium, Trichoderma, and Penicillium, Dowding (1970) reported that an increase in average temperature enhances both the activity of microorganisms and the number of insects, such 
as beetles, which are known vectors for sapstain fungi. A similar investigation of the effect of temperature on the growth of microorganisms was performed on yellow-poplar wood chips stored outdoors (Gambetta and Orlandi 1973). During their study, Gambetta and Orlandi (1973) recorded temperatures within the pile as high as $67^{\circ} \mathrm{C}$ from March - May and as low as $60{ }^{\circ} \mathrm{C}$ from January - February. The highest number of bacteria and molds were observed in the zones of the pile where the temperature reached their highest level (Gambetta and Orlandi 1973). While studying the interaction between microorganisms found in birch and aspen pulpwood, Henningsson (1967) demonstrated that not only the distribution of microorganisms within lumber piles varied with temperature but the competitive ability of certain species varied as well. Thus, the role or function, not just the appearance, of each microorganism with in the colonizing community also may affected by variable temperature conditions and are an important part of determining the microbial ecology of wood.

\section{Moisture}

The activity of wood inhabiting microorganisms and the interaction amongst them is directly influenced by the moisture content of wood (Humphrey and Siggers 1933; Henningsson 1967). The high moisture content of freshly cut logs and lumber encourages microbial growth (Panshin and de Zeeuw 1980). Up to a point, all microbial propagules

require moisture for germination and growth. Although all physical factors have some influence on microbial growth, Pasanen et al. (1992) stated that fungal growth is controlled mainly by the moisture content of a substrate. For fungi, the minimum moisture requirement is generally between $26-32 \%$ for decay and optimal growth occurs around 40\% (Rayner and Todd 1979). Wilkinson (1979) stated that below a wood moisture content of $20 \%$ fungi cease to grow. Although a higher moisture content is required for initiation of decay by fungi, once established many decay fungi can survive at a much lower moisture level (Rayner and Todd 1979). Although Rayner and Todd (1979) reported that fungal colonization begins to decline when the moisture content of wood reaches $40 \%$, other reports have indicated that some fungi can colonize wood with a higher moisture contents. For example, during an investigation that focused on the alteration of wood chips 
stored in a pile, Gambetta and Orlandi (1973) reported that several fungi were isolated from piles where the moisture content reached as high as 65\%. In contrast to fungi, bacteria normally attack wood when it is extremely wet, especially when stored in ponds. Rayner and Todd (1979) reported that as the moisture content of wood increases above $40 \%$, conditions become increasingly anaerobic and more suited to colonization by many bacteria. Anaerobic bacteria, such as Bacillus sp, colonize materials such as water-logged wood because oxygen is not required for their growth (Wilkinson 1979). Although many physical factors influence the growth of microorganism, it is apparent that wood moisture content and aeration play an important role in growth of microflora on wood, however, the conditions that are required may differ amongst species (Rayner and Todd 1979).

\section{$p H$}

The $\mathrm{pH}$ of a substrate also may affect the species colonizing that substrate as well as the rate at which they grow. Butcher (1968) stated that the majority of fungi produce their best growth at a $\mathrm{pH}$ of 5.0-6.0. As mentioned in relation to other physical factors, the optimum $\mathrm{pH}$ conditions for the growth of certain microorganism also is species dependent. For example, the fungi Aureobasidium pullulans, Cladiosporium herbarum, and Penicillium sp grow best between a $\mathrm{pH}$ of 4.0 and 5.0, while Chaetomium globosum, Absidia sp, and Helminthosporium sp experience their greatest amount of growth at a $\mathrm{pH}$ between 6.0 and 7.0 (Butcher 1968). Bacteria have a wider $\mathrm{pH}$ range for optimum growth than fungi, however their growth is highly species dependent. The optimum $\mathrm{pH}$ of most bacteria is seven or higher, however, some bacteria have been reported to thrive at a $\mathrm{pH}$ below seven (Henningsson 1967). For example, B. subtilis, exhibits the greatest amount of growth in the $\mathrm{pH}$ range of 5.5 to 8.5 , while $B$. macerans has a $\mathrm{pH}$ range for growth ranging from 2 to 8 (Buchanan and Gibbons 1974). Wood is commonly known to be acid in nature. Yeasts and fungi as opposed to other microorganisms consistently grow well at a low $\mathrm{pH}$ level and should be well suited for colonization of wood. However, no reports could be found which investigated the relationship of wood $\mathrm{pH}$ and yeast colonization. 
When assessing the $\mathrm{pH}$ of wood, consideration must be given to the variation associated within a single species. Yellow-poplar, for example, has been reported to have a $\mathrm{pH}$ of $5.43 \pm .21$ (Koch 1985). Highley and Lutz (1970), during their investigation of bacterial attack of water-stored bolts, documented yellow-poplar as having a $\mathrm{pH}$ of 4.5. In woods such as ash, maple, sycamore, and poplar, extreme differences in $\mathrm{pH}$ were found in a study performed by Gray (1958) when compared with species of oak, teak, and redwood. These findings also proved that not much reliance can be placed on $\mathrm{pH}$ studies of wood when numerous replicates are not done. The nature of wood acids, the existence of inhibitory substances in wood, and the amount of moisture present all have influencing factors which are not precisely known. Gray (1958) stated in general terms that the $\mathrm{pH}$ of wood drifts slightly in the acidic direction, especially as the acids in the wood become extracted with the water. This may explain the inconsistency of the $\mathrm{pH}$ values of yellow-poplar reported in the studies mentioned above. Another study which measured the $\mathrm{pH}$ during the investigation of the ecology of Pinus radiata sapwood, showed a drop in $\mathrm{pH}$ during the experimental period where the $\mathrm{pH}$ fell from 5.4 to 4.9 (Butcher 1968). This change in $\mathrm{pH}$ may be related to the effect of other influential forces over time.

Although extractives and other substances, such as water, present in wood cause changes in the $\mathrm{pH}$, wood $\mathrm{pH}$ also may be altered by colonizing microorganisms. Fungi, such as Trichoderma sp and most brown-rot fungi produce oxalic acids during growth. Several bacterial species also have the ability to produce certain organic acids during development. Bacillus sp, for example, has been reported to produce low molecular weight acids such as acetic acid and isobutyric acid (Asante and Neal 1964). These acids aid in the alteration of a substrate such as wood (Asante and Neal 1964). Conversely, some bacteria have the ability to raise the $\mathrm{pH}$ of wood. This occurs through the liberation of ammonia during nitrogen utilization. For example, in a study performed on yellow poplar, several unidentified focus bacteria caused an increase in wood $\mathrm{pH}$ during colonization (Highley and Lutz 1970). The ability to alter the $\mathrm{pH}$ of a substrate is not limited to fungi and bacteria. Certain yeast species also have the capability to alter the $\mathrm{pH}$ of a substrate. This 
occurs through the excretion of organic acids as end products of metabolic activity of yeasts (do Carmo-Sousa 1969).

\section{Lumber stacking practices}

The lumber stacking practice or pile configuration may influence colonizing microorganisms as well as certain physical factors with in the stack. Freshly sawn lumber taken from the green chain may either be dead-stacked or stickered-stacked. The latter method is employed when the lumber is going to be air-dried or kiln-dried. In a stickerstacking configuration, dried wooden strips or "stickers" (1 $1 \frac{1 / 4-1}{1 / 2}$ by $3 / 4-1$ inch) are placed between each layer of lumber at 16-24 inch intervals to enhances air-flow between lumber surfaces. Stickering aides lumber drying and is the optimum lumber stacking configuration to reduce discoloration. Dead-stacking of lumber involves stacking each layer of lumber on top of each other without stickers. Once stickered lumber is dried it is often deadstacked to reduce volume during shipping and wrapped in plastic or water-proof materials (Bryne and Smith 1987). This plastic or weather-proof material may fail during the shipping process, exposing the dried lumber to the environment. Under such conditions, the moisture content of lumber may increase sufficiently enough to allow microbial colonization and its attendant discoloration. Therefore, dead-stacking lumber represents the most conducive conditions necessary for the development of discoloration during the process of drying green lumber.

\section{Sum mary}

By understanding influential physical factors, the identity of microorganisms in a natural environment and their interaction when subjected to different seasonal effects, the field of biological control can successfully be introduced and developed in the wood industry. Many papers have been included and discussed in this review. These reports should be recognized and incorporated into a study which focuses on developing a biologically based preservative to be used on freshly sawn lumber by first investigating the microbial ecology

of that same freshly sawn lumber. In the meantime, available literature does not seem to contain sufficient studies of the microbial ecology of freshly sawn hardwood lumber and no 
studies have been directed towards developing biological control agents to inhibit the discoloration of lumber. 


\section{REFERENCES}

ASANTE, G. S., AND A. L. NEAL. 1964. Characterization of fungistatic substances produced by a Bacillus antagonistic to Ceratocystis ulmi. Phytopathology 54(7): 819-822.

BAMBER, R. K., AND F. R, HuMPHREY. 1964. Variations in sapwood starch levels in some Australian forest species. Australian Forestry Commission of New South Wales.

BENKO, R. 1986. Protection of wood against the blue stain. Int. Cong. of IUFRO. Reference \# 18. Ljubljana. Yugoslavia.

1987. Antagonistic effects of some mycorrhizal fungi as biological control of bluestain. Int. Res. Group on Wood Preserv. Stockholm, Sweden. IRG/WP/1314.

----------. 1988. Bacteria as possible organisms for biological control of blue-stain. Int. Res. Group on Wood Preserv. Stockholm, Sweden. IRG/WP/1339.

1989. Bacterial control of blue-stain on wood with Pseudomonas cepacia 6253. laboratory and field test. Int. Res. Group. Stockholm, Sweden. IRG/WP/1380.

----------., AND T. L. HighLY. 1990A. Selection of media on screening interaction of wood attacking fungi and antagonistic bacteria. 1. Interaction on agar. Mater. Orgon. 25(3): 161171.

attacking fungi and antagonistic bacteria. 2. Interaction on wood. Mater. Orgon. 25(3): 171180.

BROCK, T. D. 1987. The study of microorganisms in situ: progress and problems. Page 2 in M. Fletcher, and T. R. G. Gray, eds. Ecology of Microbial Communities $41^{\text {st }}$ Symposium of the society for general microbiology. University of St. Andrews..

BRyNe, T., AND R. S. SMith. 1987. Protection of lumber in Canada: Current practices, future trends. In IUFRO - Sessions on the storage of softwoods. Ontario, Canada. p. 1-15.

Buchanan, R. E., AND N. E. GiBbons (EDs). 1974. Bergey's manual of determinative bacteriology.

ButCHER, J.A. 1968. The ecology of fungi infecting untreated sapwood of Pinus radiata. Can. J. Bot. 46: 1577-1589.

Chalutz, E. 1990. Postharvest biocontol of green and blue mold and sour rot of citrus fuits by Debaryomyces hansenii. Plant Disease 74(2):134-137. 
DAVIDSON, R. W. 1935. Fungi causing stain in logs and lumber in the southern states including five new species. J. Agr. Res. 50: 789-807.

DAWSON-ANDOH, B. E., AND J. J. MORRELL. 1997. Biological protection of freshly sawn sapwood from biological discoloration. Pages 3-9 in Prevention of discoloration in hardwoods and softwood logs and lumber. For Prod. Soc. Publications.

, AND R. LOVELL. 2000. Effect of nutrients on spore germination of Gliocladium roseum and Ophiostoma piceae. Wood Fiber Sci. 32(1): 116-124.

DeAcon, J. W. 1997. Modern Mycology, $3^{\text {rd }}$ Edition. Blackwell Science Ltd. 4: 188-193, $205-$ 211.

DO CARMO-SousA, L. 1969. Distribution of yeast in nature. Pages 79-105 in Rose, A. H. and J. S. Harrison, eds. The Yeast. Vol. 1. Biology of the yeast. Academic press, Inc. London.

DowDING, P. 1970. Colonization of freshly bared pine sapwood surfaces by staining fungi. Trans. Br. Soc. 55(3): 399-412.

EllwoOd, E. L., AND B. A. EcKLUND. 1959. Bacterial attack of pine logs in pond storage. Forest Prod. J. 9(9): 283-292.

Filonow, A. B., H. S. Vishniac, J. A. Anderson, And W. Jansiewicz. 1996. Biological control of Botrytis cinerea in apple by yeast from various habitats and their putative mechanisms of antagonism. Biol. Control 7:212-220.

Freeman, G., A. J. BAIllie, AND A. MACINNES. 1948. Bacterial degradation of carboxymethyl cellulose and methyl ethyl cellulose. Chem. Indus. 5: 79

GambettA, A., AND E. ORLANDI. 1973. Microbiological alteration of poplar wood chips stored in the form of chips. USDA. National Agr. Library. July 11, 1979. Dep. of the Secretary of State, Translator Bureau: 31-40.

GARRAWAY, M. O., AND Evans, R.C. 1984. Nutrition as a basis for the study of fungi. Fungal Nutrition. New York. John Wiley and Sons, Inc. 1-3, 20.

GraY, V. R. 1958. The acidity of wood. J. Institut. Wood Sci. 1: 58-64.

GrEAVES, H. 1971. The bacterial factor in wood decay. Wood Sci. Technol. 5:6-16.

. 1965. Effect of bacterial action on some cubes in shake cultures. Holz und organismen. International Symposium. Duncker and Humbolt. Berlin. p. 61. 
, AND J. F. LEVY. 1968. Microbial associations in the deterioration of wood under long-term exposure. Pages 429-443 in A. H. Walters and J.J Elphick, eds. Biodeterioration of materials. Microbiological and applied aspects. Elsevier, Amsterdam.

HENNINGSSON, B. 1967. Interaction between microorganisms found in birch and aspen pulpwood. Stud. Forest. Suec. 53: 1-31.

Highley, T. L., AND LuTZ, J. F. 1970. Bacterial attack of water-stored bolts. Forest. Prod. J. 20(4): 43-44.

Humphrey, C. J., AND P. V. Siggers. 1933. Temperature relations of wood destroying fungi. J. Agric. Res. 47: 997-1008.

JACQUOIT, C. 1962. Récherches sur la conservation des bois feuiller utilises en papaterie. C. R. Acad-Agric. Fr, Mars: 292-296.

JACQuOIT, C., AND D. LAPETITE. 1967. Récherches sur la rôle de bactéries dans la conservation des copauux de bois pepe stockẻs en tas. C.R. Acad. Agric. Fr. 53(12): 899902.

JANISIEWICZ, W. J. 1988. Biocontrol of postharvest diseases of apples with antagonistic mixtures. Phytopathology 78: 194-198.

1994. Nutritional characterization of natural microflora of apple and its possible role in selection of biocontrol agents. Phytopathology 84: 1152.

---------. 1996. Ecological diversity, niche overlap, and coexistence of antagonists used in developing mixtures for biological of postharvest diseases of apples. Phytopathology 86: 473.

AND B. BORS. 1995. Development of a microbial community of bacterial and yeast antagonist to control wound-invading post-harvest pathogens to fruits. Appl. Environ. Microbiol. 61(9): 3261-3267.

---------., J. USALL, AND B. BORS. 1992. Nutritional enhancement of biocontrol of blue mold on apples. Phytopathology 82: 1364.

KAARIK, A. 1975. Succession of microorganisms during wood decay. Pages 39-51 in W. Liese, eds. Biological transformation of wood by microorganisms. Springer. Berlin.

KANG, S., AND J. J. MorRell. 2000. Fungal colonization of Douglas-fir sapwood lumber. Mycologia. 92(4):609-615. 
Kellman, A., AND E. B. Cowling. 1965. Cellulase of Pseudomonas solanacoarum in relation to pathogenesis. Phytopathology 55(2): 148-155.

KNUTH, D. T. 1964. Bacteria associated with wood products and their effect on certain chemical and physical properties of wood. Diss. Abstr. 25(4): 2, 175.

--------., AND E. MCCOY. 1962. Bacterial deterioration of pine logs in pond storage. Forest Prod. J. 12(9): 437-442.

$\mathrm{KoCH}$, P. 1985. Utilization of hardwoods growing on southern pine sites. USDA. For. Serv., Agric. Handbook \#605 3710. U.S. Govt. Print. Off. Washington, D.C. 3: 453.

LAST, F. T. AND D. PRICE. 1969. Yeast associated with living plants and their environments. Pages 190-218 in Rose, A. H. and J. S. Harrison (eds.). The Yeast. Vol. 1: Biology of the yeast. Academic Press, Inc. London.

LEVY, J. F. 1975. Colonization of wood by fungi. Pages 16-23 in W. Liese, ed. Biological transformation of wood by microorganisms. Springer, Berlin.

LIESE, W., AND G. KARNOP. 1968. On the attack of coniferous wood by bacteria. Holtz RohWerkstoff 26: 202-8.

Lutz, J. F., C. G. Duncan, AND T. C. Schaeffer. 1966. Some effects of bacterial action in rotary-cut southern pine veneer. Forest Prod. J. 16(8): 23-28.

Maloy, O. C., AND V. S. RoBINSON. 1968. Microorganisms associated with heartrot in young Grand fir. Can. J. Bot. 46(3): 306.

McCreary, M., B. CoesenzA, And A. L. Shigo. 1965. Bacteria isolated from decays and discolorations in northern hardwoods. Phytopathology 55(1): 129-130.

MERCIER, J. AND C. L. WiLSON. 1994. Colonization of apple wounds by naturally occurring microflora and introduced Candida oleophila and their affects on infection by Botrytis cinerea during storage. Biological Control 4:138-144.

PAnSHIN, A. J., AND Z. DE ZEEUW. 1980. Textbook of wood technology. McGraw-Hill, Inc.

PAYNE, C. AND A. BRUCE. 1999. Screening if bacteria, yeast and Trichoderma isolates for antagonism toward stain and mould fungi on agar media and wood. Presented at the $30^{\text {th }}$ annual meeting of the international research group on wood preservation. 
-------., C., A. BRUCE, AND H. STAINES. 2000. Yeast and bacteria as biological control agents against fugal discoloration of Pinus sylvestris blocks in laboratory-based tests and the role of antifungal volatiles. Holzforschung 54: 563-569.

Pasanen, A. L., T. JuUtinen, M. J. Jantunen, And P. Kalliokoski. 1992. Occurrence and moisture requirements of microbial growth in building materials. Int. Biodet. Biodeg. 30: 273-283.

PICKUP, R. W., AND J. R. SAUNDERS. 1996. Molecular approaches to environmental microbiology. Ellis Horwood Limited. University Press. Cambridge. p. 1.

RAYNER, A. D. M., AND N. K. TODD. 1979. Population and community structure and dynamics of fungi in decaying wood. Advan. Botan. Res. 7: 333-420.

Rossell, S. E., E. G. M. ABbot, AND J. F.Levy. 1973. Bacteria and wood. A review of the literature relating to the presence, action, and interaction of bacteria in wood. J. Inst. Wood. Sci., 6: 28-35.

SCHEFFER, T. C., AND R. M. LindGREen. 1940. Stains of sapwood products and their control. USDA. Washington, D. C. Techn. Bull. 714. 122pp.

Seifert, K. A., W. E. Hamilton, C. Breuil, AND M. Best. 1987. Evaluation of Bacillus subtilis $\mathrm{C} 186$ as a potential biological control of sapstain and mold on unseasoned lumber. Can. J. Microbiol. 33(1): 102-107.

SHIELDS, J. K. 1969. Microflora of eastern Canadian wood chip piles. Mycologia. 61(6): 11651168.

SHIGO, A. L. 1966A. Organism interaction in decay and discoloration in beech, birch, and maple. US Forest Service Research Paper, NE-43.

--------. 1966B. Decay and discoloration following logging wounds on the northern hardwoods. US Forest Service Research Paper, NE-47.

--------. 1965. Decay and discoloration following logging wounds on the northern hardwoods. US Forest Service Research Paper, NE-47.

--------., AND W. E. HILLIS. 1973. Heartwood, discolored wood, and microorganisms in living trees. Ann. Rev. Phytopathol. 11: 197-222.

Sorenson, W. G., J. Simpson, AND J. DutKIEWICZ. 1991. Yeasts and yeast-like fungi in stored timber. Int. Biodet.27: 373-38. 
True, R. P., AND E. H. Tyron. 1966. Butt decay in yellow-poplar sprouts in West Virginia. W. Virginia Univ. Agric. Exp. Station Bull. 541T. 67 pp.

Uzonovic, A., D-Q. Yang, P. Gagne, C. Breuil, L. Bernier, A. Bryne, M. Gignac, And S. H. KIM. 1999. Fungi that cause sapstain in Canadian softwoods. Can. J. Microbiol. 45(1): 914-922.

WAlKer, G. M., AND A. H. MCLEOD. 1995. Activity of killer yeasts against plant pathogenic and wood biodeteriogenic fungi. Pages 91-104 in R. Miller, ed. Microbe-Plant Interactions. University Press. Greenwich.

Wilkinson, J. G. 1979. Industrial Timber Preservation. Associated Business Press. London.

WILSON, M., AND S. E. LINDOW. 1994. Ecological similarity and coexistence of epiphytic icenucleating Pseudomonas syringae strains and nonice-nucleating biological control agent. Appl. Environ. Microbiol. 60: 3128.

Wisniewski, M., C. Biles, S. Droby, R. Mclaughlin, C. Wilson, and E. Chalutz. 1991. Mode of action of the postharvest biocontrol yeast, Pichia guilliermondi. Characterization of attachment to Botrytis cinerea. Physiological and Molecular Plant Path. 39:245-258.

ZABEL, R.A. 1953. Lumber stains and their control in northern white pine. J. of Forest Prod. Res. Soc. September: 1-2. 


\title{
Chapter 3
}

\section{Microbial ecology of freshly sawn yellow-poplar (Liriodendron tulipifera L.) lumber in two seasons: Part I. Fungi.}

\author{
Mark R. Mikluscak \\ Graduate Student
}

and

\author{
Benjamin E. Dawson-Andoh \\ Associate Professor \\ Division of Forestry \\ West Virginia University \\ Morgantown. WV. 26506-6125
}

\begin{abstract}
The microbial ecology of yellow-poplar lumber sawn and stored in the spring and summer of 2000 was studied. Samples were analyzed for fungi, bacteria, and yeast. This is the first of three-papers in a series that reports on the abundance, identity, and diversity of the microorganisms that were isolated from the yellow-poplar lumber samples. The primary focus of this paper is filamentous fungi. A total of 427 fungal isolates were obtained from test samples over both seasons and identification included fourteen species representing twelve genera. Nearly $15 \%$ of these fungal isolates were unable to be identified. In total, fungal colonies accounted for $41 \%$ of the total abundance of microorganisms that were isolated from samples during this entire study. Penicillium implicatum and Aspergillus versicolor were the predominant fungal species identified and accounted for $29.7 \%$ and $14.5 \%$, respectively, of the total fungal isolates. Both of these species were isolated at
\end{abstract}


every sampling period in this study. Penicillium was the most commonly isolated genera and identification included: P. implicatum, P. oxalicum, and P. solitum.

\section{INTRODUCTION}

Discoloration of freshly sawn lumber caused by fungi is a major source of revenue loss to the forest products industry (Morrell and Dawson-Andoh 1998; Scheffer 1973). The microbial agents identified as the primary cause of this discoloration are mold and sapstain fungi. Currently, chemical biocides are employed to control this discoloration of wood caused by mold and sapstain fungi. Although effective, the benefits of these chemicals may be outweighed by their potential negative impact on humans, animals, plants, and the environment in general. Increased regulation in relation to chemicals used in the wood industry in recent years has led to the search for alternative methods of preventing the microorganisms that cause this discoloration of wood. One potential alternative method for the control of mold and sapstain discoloration of lumber is biological control. Studies involving biological control have discovered that some components of the colonizing microflora can regulate the activity of detrimental microorganisms and control can be increased by basic manipulation (Deacon 1991). Biological control agents (BCAs) are living organisms that are introduced into a system to inhibit or prevent the growth of microorganisms that cause undesirable effects, such as the sapstain discoloration of wood. Because BCAs are living organisms, their propagules must germinate or grow to enable them to exert the desired effect. Janisiewicz (1998) states that to achieve success in implementing a biological control system, BCAs must be ecologically fit or competent for the target niche. In order to identify potential BCAs that are ecologically adapted to the target substrate, the ecology of these microorganisms that naturally colonize the substrate should be determined and used for the development of the biological control system. Some success using this strategy to develop commercial biological control system has been attained in the prevention of postharvest diseases of fruits, vegetables, and flowers (Janisiewicz 1988, 1994, 1996; Janisiewicz et al. 1992; Janisiewicz and Bors 1995; Lindow 1991, 1994; Wilson and Lindow 1994). This approach should also speed up the screening process for biological control agents. 
Microbial ecology examines the relationship between microorganisms and their environment (Pickup and Sanders 1996). Few studies concentrating on the microbial ecology of wood exist. Greaves (1972) reported on the microbial ecology of CCAtreated and untreated softwood stakes, but focused on the exposure of these stakes to tropical soils. A similar study involving the microbial ecology of wood was performed by Dutkiewicz et al. (1992). Although this study involved the microbial ecology of wood, focus was placed on the endotoxins produced by isolated microorganism and the evaluation of a sampling device designed to quantify microorganisms on wood. Additional ecological studies of wood have focused only on one or two components of microorganisms that colonize wood (Sorenson et al 1991; Dutkiewicz 1989; Kang and Morrell 2000). Seifert and Grylls (1992) and Uzonovic et al. (1999) have studied the microbial ecology of softwood lumber in Canada. In these studies, the focus was on the identification of mold and sapstain fungi that caused discoloration of green lumber. A similar study was recently performed on the fungal colonization of Douglas-fir sapwood lumber in Oregon, but once again reported on one component of the microflora - fungi (Kang and Morrell 2000).

The objective of this research work was to study the microbial ecology of freshly sawn hardwood lumber with focus on the isolation, occurrence, and identification of three major groups of microorganisms during spring and summer of the year 2000. Yellow-poplar (Liriodendron tulipifera L.), a hardwood species of local and regional economic importance (Payne and Bruce 1999; True and Tyron 1967), was chosen as the model wood species. This paper reports on the identity, frequency, and species diversity of isolated fungi. Bacteria and yeasts isolated and identified from the same boards in this study are reported in Part two (Chapter 4) and Part three (Chapter 5). 


\section{MATERIALS AND METHODS}

\section{Lumber}

Yellow-poplar trees (20" diameter at breast height) were felled and bucked into logs. These yellow-poplar trees were obtained from the West Virginia University Research Forest, which is located approximately 12 miles east of Morgantown, WV. Logs were examined prior to processing to ensure that discoloration was not present and sawn into nominal 8/4 X variable width ( $>6 \mathrm{ft}$.) boards within one week of being felled. Lumber was produced in spring (3/1/00) and summer (7/15/00), dead-stacked immediately, and the experiment commenced.

\section{Construction of Lumber Stack}

Yellow-poplar lumber boards taken directly from the green chain were stacked in an “open" dead-stack system. The stacking system is described as open because it was not wrapped in plastic and remained exposed to ambient environmental conditions throughout the study. Dead-stacking of lumber involves placing each layer of boards directly on top of each other without drying stickers. After lumber is processed, it is often dead-stacked for a variable period of time prior to seasoning or finishing. Lumber also is dead-stacked, after drying, to reduce shipping volume and then wrapped in plastic or water-proof material preceding distribution (Byrne and Smith 1987). Once lumber is dried, it should no longer be susceptible to microbial action unless rewetting occurs during shipping (Payne et al. 2000). Lumber package wraps often fail during handling and transportation, exposing the dried lumber to the environment. This reintroduces moisture and subsequently microbial contamination. The dead-stack design was used in this study to create the worst possible scenario and therefore the most conducive environment for fungal colonization.

The (dead-stacked) lumber package measured approximately 2.5 feet in width and 1.6 feet in height. Clear plastic was placed on top of the lumber stack and weighed down by cinder blocks. This covering was used to provide protection from direct rainfall. The deadstacked lumber package was placed on 4 inch $\mathrm{x} 4$ inch billets resting on cinder blocks and resulted in a clearance of approximately 1.5-2.0 feet above the ground (Figure 1). During 
the summer portion of this study, a sheet of clear plastic was placed on the ground under the stack to retard the growth of plants below the stack. In spring, the plastic sheet was not required due to the lack of plant growth and the cinder blocks sat directly on the ground. In such a package configuration system, the outer-most lumber boards are completely exposed and more vulnerable to changing environmental conditions than the inner sections of lumber pile. Often the result is greater variation in temperature and moisture contents of boards located in this outer layer. Therefore, the outer boards were not sampled during this study, but served as a barrier to retain moisture and ensure adequate conditions for colonization. The inner boards that constituted the sampling zone consisted of three rows and three columns and were categorized as top, middle, and bottom to represent different sections of the stack (Figures 2 and 3). Prior to each season, three boards were randomly chosen from the inner zone (one from each section of the sampling zone) to be sampled. The same boards were sampled for the length of each season to reduce the variability between boards. On each sampling date, the lumber stack was torn down to conduct the sampling. On completion of sampling, the lumber stack was re-piled with each board placed in its original location within the stack. Fresh material was used at the start of each season and the lumber stack was sampled after four different periods of storage after processing: Day 0, 3, 21, and 60 .

During the spring portion of this study, a stickered yellow-poplar lumber stack was set up on the same date and at the same location. This was a separate experiment performed only to measure the difference in moisture retained in the contrasting stacking systems. Green yellow-poplar lumber, processed exactly as described earlier in relation to the dead-stack, was taken directly from the green chain and sticker-stacked. In this stacking configuration, dried wood strips (stickers) measuring 1-1/4 X 3/4 inches were placed at 16-24 inch intervals between each layer of lumber and at right angles to the long axis of the boards. 


\section{Lumber Appearance}

On each of the sampling dates in this study, the general appearance of the entire stack and each of the boards were examined prior to sampling. The entire stack was torn down, visual observations were recorded and sampling commenced.

\section{Physical Factors}

\section{Ambient temperature and precipitation}

Climatological data, which included average ambient temperature, precipitation and relative humidity, recorded during the period of this study was obtained from two sources: National Climatic Data Center (NCDC) and the West Virginia University (WVU) Research Forest. The NCDC local climatological data was recorded at the Hart Field Airport in Morgantown, WV (Elevation: 1248 feet). Hart Field Airport is located approximately 8 miles east of the WVU Research Forest (Elevation: 2600 feet). Data from WVU Research Forest was incomplete due to equipment failure and the information that was available at this site was included only to demonstrate the differences in precipitation and average ambient temperature at the two sites (Table 1).

To gain a better understanding of the ambient conditions in the period leading up to sampling, an average value was calculated between consecutive sampling periods from the data that was available. The calculated average for ambient temperature, relative humidity, and precipitation between consecutive sampling periods was used for comparison in this study instead of the data recorded on the actual sampling dates (which may have deviated from the norm and skewed results). Therefore, in both spring and summer, respectively, three averages were calculated for each atmospheric reading (ambient temperature, relative humidity, and precipitation) - between Day 0 and 3, between Day 3 and 21, and between Day 21 and 60 (Tables 2 and 3). 


\section{In-stack temperature}

On the initial processing date of the lumber (Day 0), a temperature probe was placed between the center rows of the lumber pile where it remained for the rest of the study. The in-stack temperature was recorded only on each sampling date.

\section{Moisture Content}

Samples taken with an increment borer fitted to an electric drill were analyzed to determine the wood moisture content. Moisture content samples were taken from an area 12 inches in from either end of the lumber board in the sampling zone (Figure 4). After collection, samples were immediately placed in sterile zipped plastic sample bags for transportation, processing, and evaluation in the laboratory. In the laboratory, each sample was weighed to obtain the green weight and dried at $103 \pm 2^{\circ} \mathrm{C}$ in a convectional drying oven until a constant weight was reached. Dried wood samples were allowed to cool in a dessicator, containing pre-dried dessicant before weighing. Moisture content (dry-basis) was calculated as per ASTM D 4442-92 Standard (2001).

\section{$p H$}

To determine the $\mathrm{pH}$ of boards within the stack, the sampling protocol described for taking moisture content samples was used (Figure 4). An increment borer fitted to an electric drill was employed to extract core samples from lumber. These wood core samples were taken from the same boards sampled for moisture content and microorganisms. Samples were placed in zipped plastic bags and transported to the laboratory for processing. In the laboratory, $\mathrm{pH}$ was measured as per a modified US Forest Products Laboratory procedure (Moore and Johnson 1997). One part by weight of sawdust, milled using a Wiley Mill and screened to 40 mesh, was added to 3 parts of boiled and cooled distilled water. The two components were mixed until the sawdust was completely wetted. In some cases, a 5:1 ratio of water to wood was required to completely wet the entire sample. After 5 minutes, $\mathrm{pH}$ was measured with a Corning $\mathrm{pH} /$ ion analyzer 350 that utilized a flat-surface combination electrode at $25^{\circ} \mathrm{C}$. 


\section{Sampling of Lumber}

\section{Sampling protocol}

Boards were randomly selected from the sampling zone (Figures 2 and 3) prior to the spring and summer periods and the same boards were tested at each of the sampling dates in each season to determine the $\mathrm{pH}$, moisture content, and microorganisms colonizing lumber in the dead-stack.

\section{Sampling for Microorganisms}

From those boards selected from the sampling zone of the stack (Figures 2 and 3) the center 12" section of the boards selected from the sampling zone of the stack was designated as the sampling area for microorganisms (Figure 4). This section was sterilized by swabbing the area with $90 \%$ (volume/volume, v/v) ethanol and flaming it. This technique was used to minimize isolation of surface microorganisms and their propagules. Three samples taken from different boards in the sampling zone (Figures 2 and 3) were removed using a modified $1 / 2$ inch boring bit (Figures 5 and 6) that also had been presterilized by dipping in $90 \%$ ethanol and flaming. This sampling drill bit was set to a depth of $1 / 4$ inch. The sampling device was built "in-house" and was based on similar principles of a compact drill sampler designed by Dutkiewicz et al. (1992) to quantify microorganisms in wood. The wood shavings produced from the boring bit were collected, placed into sterilized plastic bags, and transported to the laboratory on the sampling date to be processed.

\section{Isolation of microorganisms}

Microorganisms were isolated as per the protocol of Dutkiewicz et al. (1992). Wood shavings were weighed and placed in $20 \mathrm{ml}$ of sterile phosphate-buffered saline solution containing $0.1 \%(\mathrm{v} / \mathrm{v})$ Tween 80 in a $45 \mathrm{ml}$ sealable vial. The vial and its content were shaken on a rotary shaker for one hour at $100 \mathrm{rpm}$ and ten-fold serial dilutions $\left(10^{0}\right.$ to $\left.10^{-5}\right)$ were made (Pepper et al. 1995). One-tenth (0.1) $\mathrm{ml}$ aliquots of each dilution were spread on a set of duplicate malt agar plates containing tetracycline to determine total filamentous 
fungi (Dutkiewicz et al. 1992). Tetracycline was added to eliminate bacterial growth. Inoculated petri-plates were incubated at $28{ }^{\circ} \mathrm{C}$ for a minimum of 96 hours.

At the end of the incubation period, colonies were counted and isolated on sterile malt agar plates containing tetracycline to establish pure cultures (Dandurand and Knudsen 1997). Fungal colonies were then differentiated and grouped macroscopically on the basis of growth behavior on agar as well as microscopically on the basis of cellular characteristics and colony morphology (Dutkiewicz et al. 1992; Schmidt 1985). Fungal abundance was initially reported in terms of the colony forming units (CFU) per gram of wood and then transformed by using the natural $\log \left(\log _{n}\right.$ CFU/gram) (Dowdy and Wearden 1991).

The frequency of isolation of each particular species also was used to describe the fungal community. In this study, frequency was defined as the percent of fungi belonging to a particular species and isolated on a specific sampling date or sampling period.

The frequency of isolation of each species was calculated as $\mathrm{F}_{\mathrm{i}}=\left(\mathrm{I}_{\mathrm{i}} / \mathrm{I}_{\mathrm{t}}\right) * 100$.

$\mathrm{F}_{\mathrm{i}}=$ Frequency of isolation

$I_{i}=$ Number of isolation of a particular species ${ }_{i}$ during a particular sampling period

$\mathrm{I}_{\mathrm{t}}=$ Total number of fungal isolations during this sampling period

For example, if Penicillium implicatum accounted for 35 out of a total of 100 fungal isolations on Day 0 of spring, the frequency would be $35 \%[(35 / 100) * 100=35 \%]$. Using the same definition, the frequency of each fungi was also calculated for each season and for the entire study as a whole. Thus, a frequency was calculated for each fungal species on each sampling date, each season as a whole, and for the entire study (Kang and Morrell 2000; Basham and Taylor 1965). 


\section{Microbial Identification}

Fungi were identified by Dr. Tom Volk and Sean Westmorland (University of WisconsinLaCrosse, Department of Biology, LaCrosse, Wisconsin) and Dr. Emilia Rico (BCN Laboratories, Inc., Knoxville, TN) using classical methods.

\section{EXPERIMENTAL DESIGN}

This study was setup and analyzed utilizing a typical split-plot experimental design. The experiment had two main treatments. Boards were designated as the main-plot, which received the season treatment and sections of the boards designated as the sub-plot, which received the day treatments.

\section{DATA ANALYSIS \\ Physical factors}

Physical factors monitored during this study that were analyzed statistically included $\mathrm{pH}$, moisture content, average ambient temperature, relative humidity, and in-stack temperature. Using the GLM procedure of SAS a one-way ANOVA test was performed on these dependent variables to determine if a significant difference existed (in each of the physical factors) between sampling dates or between seasons.

\section{Fungi}

A Type III test of the Least Squares Means (LSM) employing the General Linear Models (GLM) procedure of the Statistical Analysis System (SAS) was performed on the abundance of fungi isolated from each board, on each sampling date and during each season. The data for the abundance of fungi was converted using the $\log _{n}$ (natural $\log$ ) of the colony forming units per gram of wood prior to analysis.

\section{Characterization of microbial community}

Various indices are available for measuring species diversity. They tend to measure the importance of a species in a community in terms of "numbers, biomass, cover or 
productivity" (Krebs 1999). Two indices, Species Evenness (SE) and Species Richness (SR) were used to express species diversity in this study.

Species Evenness was measured by utilizing the Berger-Parker Dominance Index (BPDI). This index characterizes the distribution of species abundance (May 1975). BPDI is objective, free of bias, and provides no information on the amount of species present in the sample (Brown 1985). For this study, the BPDI was defined as the proportion of all individuals that are of the most abundant species. It was calculated as the largest $\mathrm{P}_{\mathrm{i}}$ where $\mathrm{P}_{\mathrm{i}}=\mathrm{n}_{\mathrm{i}} / \mathrm{N}, \mathrm{N}=$ the total number of individuals in the sample and $\mathrm{n}_{\mathrm{i}}=$ the number of individuals in the sample from species $\mathrm{i}$.

Species Richness (SR) represents the number of species in a sample (Brown 1985). It was applied only to identified fungi. The SR index omits the evenness of abundance of microorganisms and is completely objective if the sample is random. Species Richness was used to estimate the number of species present on each sampling date and to provide an assessment of the number species in contrasting seasons, it also was calculated for fungi identified in total per season.

\section{RESULTS}

\section{Lumber}

\section{Lumber Appearance}

No sapstain or mold discoloration of lumber was observed on Days 0 and 3 of this study during either spring or summer.

A spotted pattern of discoloration was observed on boards on the third sampling period (Day 21) of spring. Pink stain and unidentified insects also were noticed on this sampling date. Lumber discoloration was more severe in the fourth and final sampling period (Day 60 ) of the spring, particularly in the top three layers of the lumber stack. Mycelial growth and a dark reddish discoloration were apparently visible on this sampling date during the spring (Day 60). 
Observations made during summer sampling were similar to those made in the spring. For example, the first observations of discoloration occurred on Day 21 of summer. Unidentified insects also were noted on boards within the lumber stack on this sampling date (Day 21). Converse to spring sampling, the discoloration observed during the summer was darker and nearly black in color. While sampling on Day 60 of summer, an extremely dark black discoloration was observed on several boards in the stack. In addition, the top layer of lumber developed a dark reddish coloration in the fourth sampling period (Day 60) of summer.

\section{Physical factors}

Environmental factors monitored during this study included ambient temperature, relative humidity, and precipitation. Due to malfunctioning of equipment at the study site (WVU Research Forest), data from the Hart Field Airport was used to explain the atmospheric conditions in the general area during this study. The data that was available from the WVU Research Forest was included to demonstrate the differences in temperature and precipitation at the two sites.

\section{Temperature}

A similar pattern of changes in average ambient temperature was observed from the data that was available at the two sites. However, the average ambient temperatures at the WVU Research Forest were, on average, 4- ${ }^{\circ} \mathrm{F}$ lower than those recorded at Hart Field. Average monthly temperatures recorded during the test period are listed in Table 4.

During the spring, the daily average ambient temperature ranged from 33 to $67^{\circ} \mathrm{F}$ at Hart Field and from 26.5 and $66.5^{\circ} \mathrm{F}$ at the WVU Research Forest. The average temperature calculated between sampling dates during the spring increased from $41.5^{\circ} \mathrm{F}$ (between Day 0 and Day 3) to $50.7^{\circ} \mathrm{F}$ (between Day 21 and 60) (Table 2). The average temperature calculated between sample dates during this same period at WVU Research Forest ranged from 36.8 to $44.6^{\circ} \mathrm{F}$ (Table 1 ). 
The daily average ambient temperature recorded at the Hart Field Airport during the summer portion of this study ranged from 51 to $80{ }^{\circ} \mathrm{F}$. Minimal variation was observed in the average temperature calculated between sampling dates during the summer ranging from 65.8 to $71.8^{\circ} \mathrm{F}$ (Table 3). Average ambient temperature at Hart Field increased from $65.8^{\circ} \mathrm{F}$ between Day 0 and 3 to $71.8^{\circ} \mathrm{F}$ between Days 3 and 21 . The average temperature decreased between Day 21 and 60 sampling $\left(67.7^{\circ} \mathrm{F}\right)$ at this site. As stated earlier, no data was available at the WVU Research Forest during summer sampling.

\section{In-stack temperature}

The temperature within the lumber stack was recorded only on each sampling date and no meaningful average could be calculated between each sampling period. The temperature recorded within the lumber stack on each sampling date was generally lower than that of the ambient air and ranged from 35.6 to $53.0^{\circ} \mathrm{F}$ in the spring and from 57.2 to $69.0^{\circ} \mathrm{F}$ in the summer (Figure 7).

\section{Relative humidity}

The daily relative humidity of the ambient air recorded at Hart Field Airport ranged from 33.3 to $95.9 \%$ and 60.6 to $97.0 \%$ in spring and summer, respectively (Tables 2 and 3). The average relative humidity calculated between each of the sampling periods during the spring increased from $49.4 \%$ between Days 0 and 3 to $63.7 \%$ between Day 21 and 60 (Table 2). During summer sampling, the average relative humidity calculated between each of the sampling periods displayed minimal variation (Table 3).

\section{Precipitation}

As described earlier, the precipitation mentioned in this study also was an average calculated between each of the sampling dates. The average precipitation between sampling periods during the spring at Hart Field ranged from 0.05 to 0.14 inches per day (Table 2). During spring, precipitation from the WVU Research Forest showed an increase from 0.20 average inches per day between Day 0 and 3 and also 0.63 inches per day from 
Day 21 to 60 at the WVU Research Forest (Table 1). During summer, the average precipitation at Hart Field ranged from 0.06 to 0.16 inches per day (Table 3).

\section{Moisture Content}

The average moisture content of dead-stacked lumber sampled during this study remained above the fiber saturation point (30\%) in both spring and summer. Average moisture contents of boards at each sample date during spring ranged from $35 \%$ to $62 \%$ (Figure 8). From Day 0 to 3, the average moisture content of boards in the dead-stack decreased from $58 \%$ to $35 \%$, and then increased for the remainder of the study during the spring.

The moisture contents of boards sampled during summer were higher on average than those observed during the spring. The average moisture content of boards sampled on each date during summer ranged from $59 \%$ to $70 \%$. The average moisture content of boards decreased from $70 \%$ on Day 0 to $59 \%$ on Day 21 , followed by an increase on Day $60(66 \%)$ (Figure 8$)$.

For the stickered lumber stack, the average moisture content of boards decreased from $58 \%$ on Day 0 to $18 \%$ on Day 60 (Figure 9).

\section{$p H$}

The average $\mathrm{pH}$ of samples taken from dead-stacked yellow-poplar lumber on each date during spring ranged from 4.6 to 4.9. A slight increase in $\mathrm{pH}$ was observed from Day 0 (4.6) to Day 21 (4.9), followed by a decrease at Day 60 (4.6) (Figure 10). During the summer, average $\mathrm{pH}$ values increased at each sampling date from Day 0 (4.6) to Day 60 (4.8) (Figure 10).

\section{Fungi}

In total, fungal abundance in spring and summer was 108.3 and 136.3 ( $\log _{n} \mathrm{CFU} /$ gram), respectively. These total values (Figure 11) for fungi exclude fungal abundance data for 
Day 0 in spring due to missing sample weights. The total fungal abundance in each sampling period ranged from 35.5 to 36.5 in spring and from 30.9 to 37.5 ( $\log n$ CFU/gram) in summer (Table 5 and Figure 11).

The greatest abundance of fungi per sampling period occurred on Day 60 in spring and Day 3 in summer (Table 5 and Figure 11). In spring, fungal abundance increased from Day 3 to Day 60, while in summer it increased from Day 0 to 3 and declined thereafter (Figure 11).

From the 427 fungal isolates obtained in this study, identification included representatives from twelve genera and fourteen species. The occurrence of each identified fungi is displayed in Table 6. This total included two Ascomycetes with the remainder of fungi classified as Deuteromycetes. Penicillium implicatum and Aspergillus versicolor were the predominant species and accounted for $29.7 \%$ and $14.5 \%$, respectively, of the total fungal isolates obtained in this study (Table 7). Both of these species were isolated on every sampling date. The genus Penicillium had the greatest number of species identified and included P. implicatum, P. solitum, and P. oxalicum (Table 6).

The percent of fungal isolates obtained at each sampling date are listed in Table 8 . Pencillium implicatum, P. solitum, and Aspergillus versicolor accounted for $21.7 \%, 10.1 \%$, and $8.7 \%$ of the total fungi isolated from Day 0 samples during spring. During summer sampling (Day 0), A. versicolor and P. implicatum accounted for $33 \%$ and $24 \%$, respectively.

Penicillium implicatum and A. versicolor represented $29.3 \%$ and $23.2 \%$ of the total fungal isolates obtained on Day 3 in the spring, while during summer, these fungi accounted for $43 \%$ and $14 \%$, respectively. 
Penicillium implicatum represented nearly $45 \%$ and $27 \%$ of the fungi isolated on Day 21 in spring and summer, respectively. Exophiala jeanselmei, which was identified only during the summer, accounted for $18 \%$ of the fungal isolates obtained on this date (Day 21). At this point of summer storage, Chaetomium globosum, a soft rot fungus also was isolated.

On Day 60 in the spring, $P$. implicatum accounted for the highest percentage $(26 \%)$ of the fungal isolates obtained on this date, followed by Graphium penicillioides and P. solitum which, represented $15 \%$ and $13 \%$, respectively. In contrast, $34.5 \%$ of the fungal isolates obtained on Day 60 in the summer were identified as Fusarium moniliforme. Also identified was Alternaria tenuissima, which reappeared and accounted for nearly $14 \%$ of the fungal isolates obtained at Day 60 in summer. Graphium penicillioides, increased from $9 \%$ of the fungal isolates obtained on Day 21 to almost $14 \%$ on Day 60 in the summer.

Unidentified colonies of fungi accounted for $17.5 \%$ and $6.5 \%$ of the total fungi isolated over all dates in spring and summer, respectively.

\section{DATA ANALYSIS \\ Physical Factors}

Using the GLM procedure for SAS, a one-way ANOVA test was performed on each of the physical factors monitored during this study with the exclusion of precipitation.

\section{Temperature}

A significant difference was detected in the average ambient temperatures between spring and summer $(\mathrm{P}<0.05)$.

\section{In-stack Temperature}

A significant difference also was detected in the temperature recorded within the stack between spring and summer $(\mathrm{P}<0.05)$. 


\section{Relative Humidity}

No significant difference was detected in relative humidity between season or day treatments in this study $(\mathrm{P}>0.05)$.

\section{Moisture Content}

A significant difference was experienced in the moisture contents of each individual board sampled in relation to season, day, and season $\mathrm{x}$ day interaction $(\mathrm{P}<0.05)$.

$p H$

In relation to each board sampled for $\mathrm{pH}$, a significant difference was detected in the interaction between season and day treatments $(\mathrm{P}<0.05)$.

\section{Fungi}

A type III ANOVA test on the abundance of fungi ( $\log _{n} \mathrm{CFU} /$ gram) indicated that no significant differences existed in the abundance of fungi isolated per board, per sampling date, or per season $(\mathrm{P}>0.05)$.

\section{Characterization of the Microbial Community}

In spring, the highest value for Species Richness (SR) of seven was observed on Days 0 and 60. However, in summer the highest SR value, also seven, occurred on Days 0 and 21. Thus, it is estimated that seven fungal species were identified from samples obtained on the above dates. When comparing the fungi identified in each season as a whole, an SR value of 24, was obtained for both spring and summer.

The Berger-Parker Dominance Index for spring and summer on average was 0.49 and 0.31 , respectively. These values represent the proportion of individuals that belonged to the most abundant species. 


\section{DISCUSSION}

\section{Physical Factors}

Many environmental factors influence fungal growth including temperature, relative humidity, and precipitation (Scheffer and Lindgren 1932). Pickup and Sanders (1996) stated that along with temperature, $\mathrm{pH}$ and moisture content also may directly influence the alteration of microbes during the colonization of wood. Consequently, $\mathrm{pH}$, moisture content, temperature, precipitation, and relative humidity determination were included in this to determine their impact on the abundance of microorganisms (fungi) colonizing freshly sawn lumber study (Scheffer and Lindgren 1932; Pickup and Sanders 1996).

\section{Ambient Temperature}

Several authors have stated that temperature affects the growth, distribution, and interaction of microorganisms (Shields 1969; Humphrey and Siggers 1933; Henningsson 1967). Further, Henningsson (1967) reports that the effect of temperature on microbial growth is seasonal. Although some differences were observed in the fungal species isolated during spring and summer, no significant differences were observed in the overall abundance of fungi.

Most fungi have an optimum growth temperature of $25^{\circ} \mathrm{C}$ (Butcher 1968). On the whole, the temperature range observed in this study appeared to have no affect on the abundance of isolated fungi. Many fungi grow at a wide range of temperatures and are consistently isolated in all seasons (Dowding 1970). A case in point is the report by Dowding (1970) which indicated that Trichoderma sp and Penicillium sp colonizing green pine sapwood displayed no seasonal variation. This is in agreement with the results of this study where $T$. harzianum (Day 0 and 60) and P. implicatum (Day 0, 3, 21 and 60), in particular, displayed no seasonal variation. Both of these fungi were isolated at the same sampling periods during both spring and summer (Table 6). Therefore, the temperature range observed in this study had minimal impact on the occurrence of these fungi. 
Overall, variability in the appearance of specific fungal species isolated from samples in both spring and summer was observed. However, the total number of species present (or the Species Richness value) in each season seemed unaffected by temperature. Eleven different species were identified during spring and twelve in the summer. It is suggested that a lower number of species occur in winter because temperature falls outside the optimum range for the growth of most fungi

\section{In-stack Temperature}

In-stack temperatures were generally lower than that of the average ambient air temperatures. Variations in the in-stack temperatures were small in comparison with that of average ambient temperature. This could be attributed to the insulating properties of wood (Panshin and de Zeeuw 1980). In both spring and summer, in-stack temperature recorded from Day 0 to Day 21 showed very little correlation with that of average ambient temperature. However, from Day 21 to Day 60 in both seasons, a correlation between instack temperature and average ambient temperature was observed. For example, in spring, in-stack temperature and the average ambient temperature increased nearly $15^{\circ} \mathrm{F}$ from Day 21 to 60. During summer, a similar relationship was observed between the in-stack temperature and the average ambient temperature on Day 21 and Day 60. A decrease of at least $7{ }^{\circ} \mathrm{F}$ was observed in both the average ambient temperature and in-stack from Day 21 to Day 60. Although possibly coincidental, this observation can be attributed to the lag in equilibration between in-stack and ambient temperature.

A type III one-way ANOVA indicated a significant difference $(\mathrm{p}<0.05)$ existed between instack temperatures in spring and summer. This would be expected between any two seasons. With respect to average ambient temperature, abundance of isolated fungi showed very little variation and no relationship could be discerned between fungal abundance and the in-stack temperature. 


\section{Moisture Content}

Moisture contents of lumber boards in the dead-stacked pile were relatively high. This can be ascribed to the dead-stack configuration of the lumber pile. The moisture content of lumber in the stickered-stack decreased steadily as expected in an air-drying operation. Microbial activity, wind speed, ambient temperature as well as elevated precipitation and relative humidity in the periods leading up to sampling also may have been contributing factors to the observed high moisture content.

Past studies indicate that the moisture content of wood affects the growth and interaction of colonizing fungi since all microbial propagules require moisture for germination and growth (Henningsson 1967; Humphrey and Siggers 1933). Panshin and de Zeeuw (1980) stated that the high moisture content of freshly cut logs and lumber encourages microbial growth. While the moisture content for optimum fungal growth is around $40 \%$, Rayner and Todd (1979) state that most fungi cease to grow on wood when moisture content falls below $20 \%$. The average moisture content of boards during each sampling period of this study never fell below 35\% and thus, a low moisture content was not identified as a limiting factor for fungal growth. Rayner and Todd (1979) reported that if the moisture content of wood is above $40 \%$, fungal growth also declines. The average moisture content readings taken during each sampling period of this study were often above $40 \%$ and no such decline in fungal abundance was observed. The effect of moisture content on microbial growth does vary with each individual species (Rayner and Todd 1979), however, no tests were performed during this study to determine the optimum range of moisture content for each individual species that was isolated.

No significant changes were observed in the abundance of fungi with respect to lumber moisture content. Although a one-way ANOVA test indicated a significant in the moisture content of individual boards between season, day, and season $\mathrm{x}$ day interaction, no such changes were observed in relation to fungal abundance. Pasanen et al.(1992) stated that in addition to moisture requirements, fungal growth is also greatly influenced by ambient 
temperature, substrate composition, and time. It is suggested that the observed moisture content range (35\% to $70 \%)$ was not limiting to microbial growth.

$p H$

The $\mathrm{pH}$ of yellow-poplar wood has been reported as $5.43 \pm 0.21$ (Koch 1985) and 4.5 (Highley and Lutz 1970). The results of this study are in reasonable agreement with these reports. Wood is a heterogeneous material and it must be assumed that $\mathrm{pH}$ measured at different locations will vary. The destructive sampling technique employed for $\mathrm{pH}$ samples in this study required that each sample be taken for a different location and may explain the variation in $\mathrm{pH}$ values in this and other studies.

Wood $\mathrm{pH}$ is affected by several factors including moisture content, precipitation, and microbial activity (Gray 1958; Highley and Lutz 1970). Gray (1958) stated that the pH of wood may decrease slightly in the acidic direction as the acids of the wood become extracted by water. This can occur by the introduction of water in the form of precipitation. Dead-stacked lumber piles used in this study were covered with plastic to minimize precipitation effects and no relationship was determined between the change in $\mathrm{pH}$, moisture content, or precipitation.

The alteration of a substrate's $\mathrm{pH}$ also can be accomplished by fungi, bacteria, and yeast (Asante and Neal 1964; Highley and Lutz 1970). This alteration can be achieved by the production of organic acids (Asante and Neal 1964; Highley and Lutz 1970). For example, the fungus, Penicillium oxalicum, has demonstrated ability to produce organic or oxalic acids during growth (Pitt 2000). Production of acids on wood often results in a lowering of the $\mathrm{pH}$. Although microorganisms with the ability to produce these acids were identified during this study, no tests were performed to determine if they influenced $\mathrm{pH}$.

Payne et al. (2000) stated that modification of the $\mathrm{pH}$ of a substrate may inhibit fungal growth, however, no tests were performed to determine the optimum $\mathrm{pH}$ range of individual fungi isolated during this study. Although a one-way ANOVA test indicated a 
significant difference in the interaction between season and day treatments $(\mathrm{P}<0.05)$, no relationship could be determined between the change in $\mathrm{pH}$ and fungal abundance.

Although optimum $\mathrm{pH}$ for fungal growth occurs at a $\mathrm{pH}$ range of 5-6, the effect of $\mathrm{pH}$ is species dependent (Butcher 1968). For example, Aureobasidium pullulans, Cladiosporium herbarum, and Penicillum sp grow best between a pH of 4.0 and 5.0 (Butcher 1968). Penicillum sp was the predominant fungal genera isolated during this study and may be due, in part, to the fact that the $\mathrm{pH}$ values of wood samples taken during this study fell in the range for optimum growth (4.0-5.0). Without further testing to confirm this, only speculative statements can be made.

\section{Relative Humidity}

Payne et al. (2000) reported that relative humidity has an indirect influence on microbial growth. This statement may be true, however, it is very difficult to prove. From the results obtained during this study, it was apparent that no direct relationship could be discerned between relative humidity and fungal abundance. Statistical analysis by way of a type III one-way ANOVA test determined that no significant differences $(\mathrm{p}<0.05)$ existed in the relative humidity at different sampling dates or seasons of this study. It could be said that relative humidity range in this study was adequate for fungal growth.

\section{Summary of physical Factors}

Overall, no apparent trend or relationship was observed between the physical factors monitored in this study and the abundance of fungi ( $\left.\log _{n} \mathrm{CFU} / \mathrm{gram}\right)$. As mentioned earlier, fungal abundance described in this study was transformed using the natural log $\left(\log _{n)}\right.$ prior to analysis. When dealing with data composed of very large and small counts, such as microorganism counts in a small experiment, it often leads to a non-normal distribution (Dowdy and Wearden 1991). Not only is the assumption of normality invalid but the variance of the treatment groups may be unequal accompanied by a lack of independence between the effects (Dowdy and Wearden 1991). This can be overcome by transformation of data (natural $\log -\log n$ ). Since the transformed data remains in the same 
order as the original observations, any conclusion about the transformed data is true for the original (Dowdy and Wearden 1991). The main disadvantage to the transformation of data in this manner is that the results are reported in unusual units (Dowdy and Wearden 1991). For example, the abundance of fungi is reported as the $\log _{n}$ (natural $\log$ ) of the colony forming units per gram of wood (Table 3).

Only a minimal difference was observed in the abundance ( $\log _{\mathrm{n}} \mathrm{CFU} / \mathrm{gram}$ ) of fungi isolated per sampling period during this study. Similarly, no significant differences were detected in fungal abundance averaged over each season. Thus, environmental factors in both spring and summer were conducive to fungal colonization. Although changes in environmental conditions may play an important role in the ability of fungi to colonize a substrate such as wood, the presence of competing microorganisms on the wood surface may be the defining factor for the colonization of wood and cannot be overlooked (Kreber and Morrell 1992; Velicheti and Morrell 1995).

\section{Fun $\boldsymbol{g} \boldsymbol{i}$}

One important attribute of biological communities is species diversity (Krebs 1999). Although variation in fungal species isolated and identified occurred in the two seasons and sampling periods, species richness seemed unaffected by temperature. Eleven and twelve different species were identified during the spring and summer, respectively.

\section{Species Richness}

The highest species richness value (seven) occurred on four different sampling periods and included Days 0 and 60 of spring and Days 0 and 21 of summer. This value represents the number of fungal species that were identified on these sampling dates. The high number of fungal species present on Day 60 of spring and Day 21 of summer can possible be related to the in-stack temperature. The highest in-stack temperature on Day 60. Similarly, the highest in-stack temperature during summer was recorded on Day 21. Although, in-stack temperature may not have affected the total fungal abundance recorded at the different sampling periods, it may have affected the amount of species 
present. The peculiarity comes in the Species Richness values observed on Day 0 in both seasons. Many fungi and molds are common components of the air and it can be expected that some of these microorganisms would find their way to the nutrient rich surface of freshly sawn lumber. However, other factors may have influenced this high number of species isolated on the initial date of processing. For example, the saw blade, itself, could have acted as an instrument of inoculation during the processing of lumber. It also is possible that colonization of these yellow poplar logs began immediately after felling. These factors, individually or in combination, could explain the inflated number of species identified on the initial sampling periods (Day 0) in both seasons.

It should be stated that although unidentified fungi might have altered the index value for Species Richness, the purpose of using this index is to gain some approximation of the species that are present in a sample. There are limitations associated with each diversity index and for this reason incorporating them as a pair gives a clearer picture of the microbial community. For this reason, the BPDI was included in the analysis of this study to determine the Species Evenness.

\section{Berger-Parker Dominance Index}

The BPDI is a measure of the Species Evenness in a sample and describes the distribution of species abundance. The BPDI for spring and summer were 0.49 and 0.31 , respectively. These values represent the proportion of all fungi that were of the most abundant species. Thus, a higher BPDI in spring suggests that the spectrum of fungi occurring in spring was more homogeneous than that of summer. This means that fewer individual species of fungi made up the total population. This is supported by the observation that three fungi, $P$. implicatum, Aspergillus versicolor, and F19 (unidentified) accounted for over $60 \%$ of the total fungal isolations during spring (Table 7). (F19 was grouped as a separate fungus based on colony morphology, but was not identified.) Fungi isolated during summer had a lower BPDI value (0.31), which suggests that the fungal community was more evenly distributed. 
The results of this study are in agreement with previous studies which indicate that different fungi colonize freshly sawn lumber after different lengths of storage subsequent to sawing (Kang and Morrell 2000; Greaves 1972; Uzonovic et al. 1999; Seifert and Grylls 1992). Based on the method of isolation used in this study, results indicate that fungi were the second most abundant group of microorganisms, representing $41 \%$ of the total population that was sampled (Figure 12). Fungi in this study comprised a large amount of the total population in each of the sampling periods trading positions only with bacteria for the greatest percentage of microorganisms isolated per sampling period. These findings are in agreement with the results of a study reported by McCreary et al. (1965) which indicated that bacteria were isolated more frequently than fungi from discolored and decayed hardwoods (McCreary et al 1965).

Few studies have examined all microorganisms that colonize wood and most studies have made fungi the primary focus. From those studies that have been reported, few have examined hardwoods and the most recent research has concentrated mainly on the fungi that colonize softwoods. Most frequently, fungi isolated from freshly sawn coniferous logs and lumber (softwoods) in Canada were identified as Ophiostoma picea and Graphium sp. (Uzonovic et al. 1999; Seifert and Grylls 1992; Kang and Morrell 2000). In this study, although Graphium sp was isolated from yellow-poplar in both spring and summer, Penicillium sp was the predominant fungus recovered during sampling. The genus Penicillium is a common component of the air and soil, which may have added to its frequency of isolation. While investigating the fungi that colonize all types of building material, Pasanen et al. (1992) reported that Penicillium sp was the most commonly isolated fungus and accounted for nearly $70 \%$ of all fungi that were obtained. Although the study performed by these authors did not focus singly on wood, but rather classified all building material together, it is still an indication of the abundance of Penicillium sp in the environment and/or the ability of this fungus to establish colonies. Penicillium implicatum, in particular, accounted for the highest percent of the total fungi isolated from yellowpoplar in this study. Penicillium implicatum is a known cause of biodeterioration and is commonly isolated from soil (Pitt 2000). Pencillium implicatum has been described as a 
very broad species (Pitt 2000). This fungus is described as a broad species because although some species are similar, they are not identical but have yet to be separated or placed into different species classifications (Pitt 2000). The second most frequently isolated fungus in this study was Aspergillus versicolor. The study of Pasanen et al. (1992), which was described earlier, also indicated that Aspergillus sp was the second most abundant fungus isolated during their study. Once again, although the fungi isolated from wood were not singled out form the rest of the building materials studied, the results accompanied by the information of this study of yellow-poplar may indicate the abundance of this fungus in the environment. Fungi that have previously been isolated from yellowpoplar, in particular, include Aspergillus sp, Fusarium sp, Penicillium sp, Trichoderma sp, and Gleosporium sp (True and Tyron 1967). All but one of these fungal genera were represented in this study.

Fungi cause the deterioration of wood in two ways, through decay and/or discoloration. Discoloration of wood is accomplished by mold and sapstain fungi, which are commonly found on wood (Seifert and Grylls 1992). Mold and sapstain fungi that have been isolated from logs and lumber in the United States are generally classified as Deuteromycetes and Ascomycetes (Scheffer and Lindgren 1932). Although the fungi recovered during sampling in this study were not investigated for their ability to cause discoloration, all fungi that were identified belonged to these two groups (Deuteromycetes, Ascomycetes). Fungi that normally cause mold and sapstain discoloration of lumber include Penicillium sp, Trichoderma sp, Gliocladium sp, and Aspergillus sp (Scheffer and Lindgren 1932). With the exception of Gliocladium sp, representatives from all of these genera were isolated during this study. Fungi identified in this study also included Dematiaceous molds such as Alternaria sp (Day 60 spring and summer), Cladiosporium sp (Day 60 spring), and Epicoccum nigrum (Day 21 summer). These fungi are known to produce dry masses of conidia that are commonly transmitted by the wind (Seifert and Grylls 1992) and also cause dark stain of wood. Cladiosporium sp and Alternaria sp, in particular, have been reported to stain Pinus radiata sapwood (Butcher 1968). In this study, discoloration in the lumber stack was initially observed after 21 days of storage in both seasons and could be attributed 
to the activity of above mentioned fungi. During summer sampling, a blackish or darker discoloration was observed than that observed in the spring. This darker discoloration could be explained by the presence of Graphium penicillioides and Exophiala jeanselmei, which were isolated at a high frequency after Day 21 of sampling during summer. Graphium sp is a known stainer of wood and Exophiala sp is a widely distributed dimorphic fungus (Kang and Morrell 2000; St-German and Summerbell 1996). Exophiala $\mathrm{sp}$ is commonly referred to as a "black yeast", and is in the same class as Aureobasidium $\mathrm{sp}$ (Kang and Morrell 2000; St-German and Summerbell 1996).

Numerous other fungal species cause the discoloration of lumber. For example, several species of Fusarium and Penicillum have been reported to be responsible for bright colored sapstains in wood (Scheffer and Lindgren 1932). A case in point is Fusarium moniliforme, which produces pink, red, or violet stains of lumber when moisture is abundant (Scheffer and Lindgren 1932). During Day 60 (summer) of this study, a reddish discoloration of lumber was observed. This bright colored discoloration could be related to the presence of Fusarium moniliforme, which accounted for $34 \%$ of the total fungal isolates on this sampling date.

Although the darkly pigmented stain fungi, which cause discoloration of wood, are of great importance to lumber producers, other resident microflora should not be overlooked. Nonpigmented fungi are noticed and investigated far less than stain fungi (Kang and Morrell 2000). At this point, the role of non-pigmented /non-decay fungi and their affect on the colonization of wood is poorly understood (Kang and Morrell 2000). Fungal succession of wood is a complex process. Besides the inhibition of growth due to environmental factors, certain fungi also can inhibit the growth of microflora through nutrient competition and the production of toxic metabolites (Leslie et al. 1976). For example, many fungi function as pioneer colonizers of wood. These pioneer organisms alter the substrate of wood and can initiate succession of particular microorganisms (Duncan and Deverall 1964). Thus, all fungi are important to characterizing the colonization pattern of the fungal community, notable pioneer fungi. Common fungi with the ability to quickly colonize wood include 
Penicillium sp, Trichoderma sp, Gliocladium sp, Hormodendrum sp, Aspergillus sp, and Alternaria sp (Duncan and Deverall 1964). These fungi are all Deuteromycetes, some of which were represented in this study (Shigo 1967). Penicillium sp and Trichoderma sp, in particular, were part of the taxa identified in this study and have been commonly been reported in literature as colonizers of wood (Shigo 1967; Kang and Morrell 2000; Seifert and Grylls 1992). These fungi are important in relation to the development of a biological control agent because they are aggressive organisms by nature and may compete with any biologically based preservative (Siefert and Grylls 1992). Both Penicillium sp and Trichoderma sp effectively degrade and utilize cellulose and have the potential to produce secondary metabolites (Johnson et al. 1960). Trichoderma sp have displayed antagonistic ability toward decay fungi and plant pathogens through the production of antibiotics (Payne et al. 2000). Trichoderma harzianum, in particular, also has demonstrated the ability to reduce colonization of sapstain fungi (Schoeman et al. 1994). These fungi should be recognized as important influential species of the colonizing community because of the possible influence they may exert on the growth of other microorganisms (Seifert and Grylls 1992).

Another point of interest derived from the results of this study, is the presence of Fusarium moniliforme and Alternaria alternata. Both fungi can produce toxic organic substances during growth. Fusarium moniliforme possesses the ability to produce Fumonisin B1, a mycotoxin, while A. alternata produces AAL, a phytotoxin (Chen et al. 1992). These two toxins are functionally similar and may be potentially harmful to animals, humans, as well as other microbes (Chen et al. 1992). Although these fungi can stain wood and may not be of interest as biological control agents they must be recognized for their ability to influence the microbial community and their potential influence on biologically based preservatives.

Penicillium oxalicum, which was identified in this study, has been documented as producing large amounts of oxalic acid during growth and causes self-inhibition (Pitt 2000). Penicillium oxalicum accounted for only a small amount of the total fungal isolations in this study and could possibly be attributed its oxalic acid production. 
Penicillium oxalicum also has demonstrated the ability to produce secalonic acid during growth (Pitt 2000). Secalonic acid is a microbial metabolite which exhibits toxicity to animals (Pitt 2000). Although the production of this acid has not been investigated for its effectiveness on fungal inhibition, potential remains for the ability to influence the colonization of wood by microorganisms (Pitt 2000). To date, the production of substances (phytotoxins, mycotoxins, oxalic acids, or secalonic acid) on wood has not been established in situ and were not investigated in this study.

Although several different species of fungi were represented in this study, Butcher (1968) states that often the resultant species of microflora recovered during a study is a function of the sampling technique employed. The fungi identified during this study were based on periodic isolations and it cannot be assumed that all fungi colonizing yellow-poplar lumber were either isolated or identified (Kang and Morrell 2000). In addition to the sampling procedure, it must be recognized that incubation conditions and the media used in this study may have limited the potential for isolation of specific microorganism and some of the microorganisms that were identified may have been simply "opportunistic colonizers" (Kang and Morrell 2000). These limitations are associated with the investigation of the microbial ecology of any substrate.

Several studies mentioned in this paper have investigated the interaction of certain species of microorganisms on wood. However, without a study that identifies microorganisms that normally colonize wood (lumber), such studies may be of limited relevance to the development of biological control agents that inhibit mold and sapstain discoloration of lumber. Andrews $(1990,1992)$ stated that biological control is "fundamentally applied ecology". Therefore, this study represents a modest beginning in the characterization of the microbial ecology of green sawn hardwood lumber. It provides some information on the abundance and types of microorganisms that naturally colonize this hardwood species and represent a step in the development of a biological control system. Future studies should examine the role of physical factors on the interaction of 
the microorganism isolated in this study. Some identified microorganisms will also be screened for their potential as biological control of mold and sapstain fungi.

\section{CONCLUSION}

1. This study provides information on the identity, occurrence, and abundance of fungi that colonize freshly sawn yellow-poplar lumber in a dead-stack configuration. Deuteromycetes were the most frequently isolated fungi during the first 60 days of outside storage.

2. Freshly sawn boards were rapidly colonized by a variety of fungi. Penicillium implicatum was isolated at every sampling period and was the predominant fungal species accounting for $29.74 \%$ of the total fungal isolations. Nearly $15 \%$ of the total fungal isolates were unable to be identified.

3. The abundance of fungi recovered from samples in this study remained relatively consistent at each of the sampling dates in both season. No statistically significant $(\mathrm{P}>0.05)$ differences in the total abundance of fungi ( $\log _{n} \mathrm{CFU} / \mathrm{gram}$ ) were observed with respect to the length of storage (up to 60 days) or season.

4. None of the physical factors monitored during the length of this study appeared to have a direct affect on the overall abundance of fungi recovered at each sampling period in spring and summer.

\section{ACKNOWLEDGEMENTS}

The authors thank Dr. Daniel Panaccione and Mr. Mark Double for their multitude of assistance; Dr. William Thayne and Dr. Mark Brown for statistical support; Mr. Jeffrey Slahor, Mr. George Mikluscak for technical and mechanical assistance; Dr. Tom Volk, Mr. Sean Westmoreland, and Dr. Emilia Rico for the identification of fungal isolates; and Mr. Robert Driscole, West Virginia University Forest Manager for processing of the lumber. 


\section{REFERENCES}

American Society for Testing And Materials. (ASTM) 2001. ASTM Standard D 4442-92. Standard test methods for direct moisture content measurement of wood and wood-base materials. West Conshohocken, PA. p 510-515.

ANDREWS, J. H. 1990. Biological control in the phyllosphere: Realistic goal or false hope? Can. J. Plant Path. 12: 300-307.

AndRews, J.H. 1992. Biological Control in the Phyllosphere. Annu. Rev. Phytopathol. 30:603-35.

Asante, G. S. AND A. L. Neal. 1964. Characterization of fungistatic substances produced by a Bacillus antagonistic to Ceratocystis ulmi. Phytopathology 54(7): 819-822.

BASHAM, J. T., AND L. D. TAYLOR. 1965. The occurrence of fungi and bacteria in normal and discolored heartwood of second-growth sugar maple in Ontario. Pl. Disease Reporter 49(9): 771-775.

BROWN, M. W. 1985. A Fortran program to calculate several diversity indices. USDA. Agric. Res. Serv. ARS-27: 24.

Byrne, T. AND R. S. SMith. 1987. Protection of lumber in Canada: Current practices, future trends. IUFRO - Sessions on the storage of softwoods. Ontario, Canada. 5: 115.

BUtChER, J. A. 1968. The ecology of fungi infecting untreated sapwood of Pinus radiata. Can. J. of Botany 46:1577.

Chen, J-P., W. P. XIE, AND C. J. MiRocha. 1992. Production of the mycotoxin fumonisin B1 by Alternaria alternata and f.sp. lycopersici. Phytopathology 82(10):1063.

Dandurand, L. C., AND G. R. KNUdSEn. 1997. Manual of Environmental Microbiology. ASM Press. Washington, D.C.

DeACON, J. W. 1991. Significance of ecology in the development of biological control agents against soil-borne plant pathogens. Biol. Sci. Technol. 1: 5-20

DowDING, P. 1970. Colonization of freshly bared pine sapwood surfaces by staining fungi. Trans. Br. Soc. 55(3): 399-412.

Dowdy, S., AND S. WeARDEN. 1991. Statistics for research. $2^{\text {nd }}$ edition. John Wiley and Sons, Inc. New York. p 348-423. 
Duncan, C. G., AND F. J. Deverall. 1964. Degradation of wood preservatives by fungi. Appl. Microbiol. 12: 57-62.

DutKIEWICZ, J. 1989. Bacteria, fungi, and endotoxin in stored timber logs and airborne sawdust in Poland. Biodeterioration Research. 2:533-547.

DutKiewicz, J., C. Kwapiszewski, S. Olenchock, AND D. Lewis. 1992. Compact drill sampler for the quantitation of microorganisms in wood. United States Patent: 50378553.

GRAY, V. R. 1958. The acidity of wood. Journal of the Institute of Wood Science. 1: 58-64.

GREAVES, H. 1972. Microbial ecology of untreated and copper-chrome-arsenic treated stakes exposed in a tropical soil. The initial invaders. Can. J. Microbiol. 18(12): 19231931.

HENNINGSSON, B. 1967. Interaction between microorganisms found in Birch and Aspen pulpwood. Stud. Forest. Suec. 53: 1-31

HighLEY, T. L., AND J. F. LUTZ. 1970. Bacterial attack in water-stored bolts. Forest Prod. J. 20(4): 43-44.

HUMPHREY, C. J., AND P. V. SigGERS. 1933. Temperature relationships of wood destroying fungi. J. of Agric. Res.47: 997-1008.

JANISIEWICZ, W. J. 1988. Biocontrol of postharvest diseases of apples with antagonistic mixtures. Phytopathology 78: 194-198.

--------. 1994. Nutritional characterization of natural microflora of apple and its possible role in selection of biocontrol agents. Phytopathology 84:1152.

-------. 1998. Biocontrol of postharvest diseases of apples with antagonistic mixtures. Phytopathology 78: 194-198.

--------. 1996. Ecological diversity, niche overlap, and coexistence of antagonists used in developing mixtures for biocontrol of postharvest diseases of apples. Phytopathology 86: 473-479.

, AND B. BORS. 1995. Development of a microbial community of bacterial and yeast antagonists to control wound-invading postharvest pathogens of fruits. Appl. Environ. Microbiol. 61(9): 3261-3267. 
--------., J. USTALL, AND B. BORS. 1992. Nutritional enhancement of biological control of blue mold on apples. Phytopathology 82: 1364-1370.

Johnson, L. F., E. A. Curl, J. H. Bond, AND H. A. Fribourg. 1960. Methods for studying soil microflora-plant disease relationships. Burgess Publishing Co. Minneapolis, MN.

KAnG, S., AND J. J. Morrell. 2000. Fungal colonization of Douglas-fir sapwood lumber. Mycologia 92(4): 609-615.

KoCH, P. 1985. Utilization of hardwoods growing on southern pine sites. USDA. For. Serv., Agric. Handbook. \#605 3710. U.S. Govt. Print. Off., Washington, D.C. p 452453.

Kreber, B., AND J. J. MorRell. 1992. Ability of selected bacterial and fungal bioprotectants to limit fungal stain in ponderosa pine sapwood. Wood Fiber Sci. 25(1): 23-24.

KreBS, C. J. 1999. Ecological Methodology. $2^{\text {nd }}$ edition. Addison-Welsey Educational Publishers, Inc. Menlo Park, CA. p 410-446.

Leslie, H., G. Morton, O. Howard, AND W. Eggins. 1976. Studies of the interaction between wood-inhabiting microfungi. Mater. Orgon. 11: 197-214.

Lindow, S. E. 1991. Determinants of epiphytic fitness in bacteria. Page 295 in J. H. Andrews and S. S. Hirano, eds. Microbial ecology of leaves. Springer-Verlag. New York.

--. 1994. Epiphytic fitness determinants in bacteria. Page 29 in D. D. Bills and S. D. Kung, eds. Proceedings of the fourth international symposium, biotechnology and plant protection. World Scientific Publishing Co. Pte. Ltd. Singapore. River Edge. New Jersey.

McCreary, M., B. Coesenza, And A. L. Shigo. 1965. Bacteria isolated from decay and discoloration in northern hardwoods. Phytopathology 55(1): 129-130.

Moore, W. E., AND D. B. Johnson. 1997. Procedures for the analysis of wood and wood products. USDA. For. Prod. Lab. For. Serv. Madison, WI. p 1-4. 
MoRrelL, J. J., AND B. DAWSON-ANDOH. 1998. Biological control: panacea or boondgle. Pages 39-44 in Biology and prevention of sapstain. A conference sponsored by the Department of Forest Products, Oregon State University. Delta Whilster Resort. BC, Canada.

Panshin, A. J., AND C. DE ZeEuw. 1980. The physical nature of wood. Pages 218-220 in Textbook of wood technology. $4^{\text {th }}$ edition. McGraw-Hill, Inc. New York.

Pasenen, A. L., T. Juutinen, M. J. Jantunen, and P. Kalliokoski. 1992. Occurrence and moisture requirements of microbial growth in building materials. Int. Biodet. Biodeg. 30: 273-283.

Payne, C. AND A. BRUCE. 1999. Screening if bacteria, yeast and Trichoderma isolates for antagonism toward stain and mould fungi on agar media and wood. Presented at the $30^{\text {th }}$ annual meeting of the international research group on wood preservation.

Payne, C., A. Bruce, And H. Staines. 2000. Yeast and bacteria as biological control agents against fungal discoloration of Pinus sylvestris blocks in laboratory-based tests and the role of antifungal volatiles. Holzforshung 54: 563-569.

PePper, I. L., C. P. Gerbe, AND J. W. BRendeCKe. 1995. Environmental Microbiology. Academic Press. San Diego, CA. p 27.

PicKUP, R. W. AND J. R. SANDERS. 1996. Molecular approaches to environmental microbiology. Ellis Hardwood Limited. University Press, Cambridge. p.1.

PITT, J. I. 2000. A Laboratory guide to common Penicillium species. $3^{\text {rd }}$ edition. CSIRO. North Ryde, Australia.

Rayner, A. D. M. AND N. K. TODD. 1979. Population and community structure dynamics of fungi in decaying wood. Advan. Botan. Res. 7:333-420.

SCHEFFER, T. C., AND R. M. LINDGREN. 1932. Some minor stains of southern pine and hardwood lumber and logs. J. of Agric.Res. Washington D. C. 45(4): 233-237.

----------, T. C. 1973. Microbiological degradation and the causal organisms. Pages 31-106 in D. D. Nicholas, ed. Wood deterioration and its prevention by preservative treatment. Vol. 1. Syracuse University Press. Syracuse, New York.

SCHMIDT, O. 1985. Occurrence of microorganisms in the wood of Norway spruce trees from polluted sites. Eur. J. of Forest Path. 15: 1-10. 
Schoeman, M. W., J. F. WebBer, And D. J. Dickinson. 1994. Chain-saw application of Trichoderma hazianum Rifai to reduce fungal deterioration of freshly felled pine logs. Mater. Orgon. 28(4): 243-250.

SEIFIERT, K. A., AND B. T. GRYLls. 1992. A survey of the sapstaining fungi of Canada. Ottawa: Forintek Canada Corp. p 1-32.

SHIELDS, J. K. 1969. Microflora of eastern Canadian wood chip piles. Mycologia 61(6): $1165-1168$.

SHIGO, A. L. 1967. Succession of organisms in discoloration and decay of wood. Reprinted from the international review of forestry research, Vol. 2. Northeastern Forest Experiment station, Forest Service. USDA. Durham, NH. p 279-283.

Sorenson, W.G., J. Simpson, And J. DutKIEWICZ. 1991. Yeast and Yeast-like fungi in stored timber. International Biodeterioration 27: 373-382.

St. German, G. AND R. Summerbell. 1996. Identifying filamentous fungi: A clinical laboratory handbook. Star Publishing Co. Belmont, CA.

True, R. P., AND E. H. Tyron. 1967. Butt decay in yellow poplar sprouts in West Virginia. West Virginia University Agricultural Experiment station. Bulletin 541T.

Uzonovic, A., D-Q. Yang, P. Gagne, C. Breuil, L. Bernier, A. Bryne, M. Gignac, AND S. H. Kim. 1999. Fungi that cause sapstain in Canadian softwoods. Can. J. Microbiol. 45(11): 914-922.

Velicheti, R. K., AND J. J. MorRell. 1995. Media enhancement of bioprotectant capabilities against wood staining fungi. Pages 245-249 in Wood preservation in the 90's and beyond. Forest Products Society. Madison, WI.

WILSON, M., AND S. E. LINDOW. 1994. Ecological similarity and coexistence of epiphytic ice-nucleating Pseudomonas syringae strains and nonice-nucleating biological control agents. Appl. Environ. Microbiol. 60: 3128. 
FIGURE 1. Cross-sectional view of dead-stacked yellow-poplar lumber

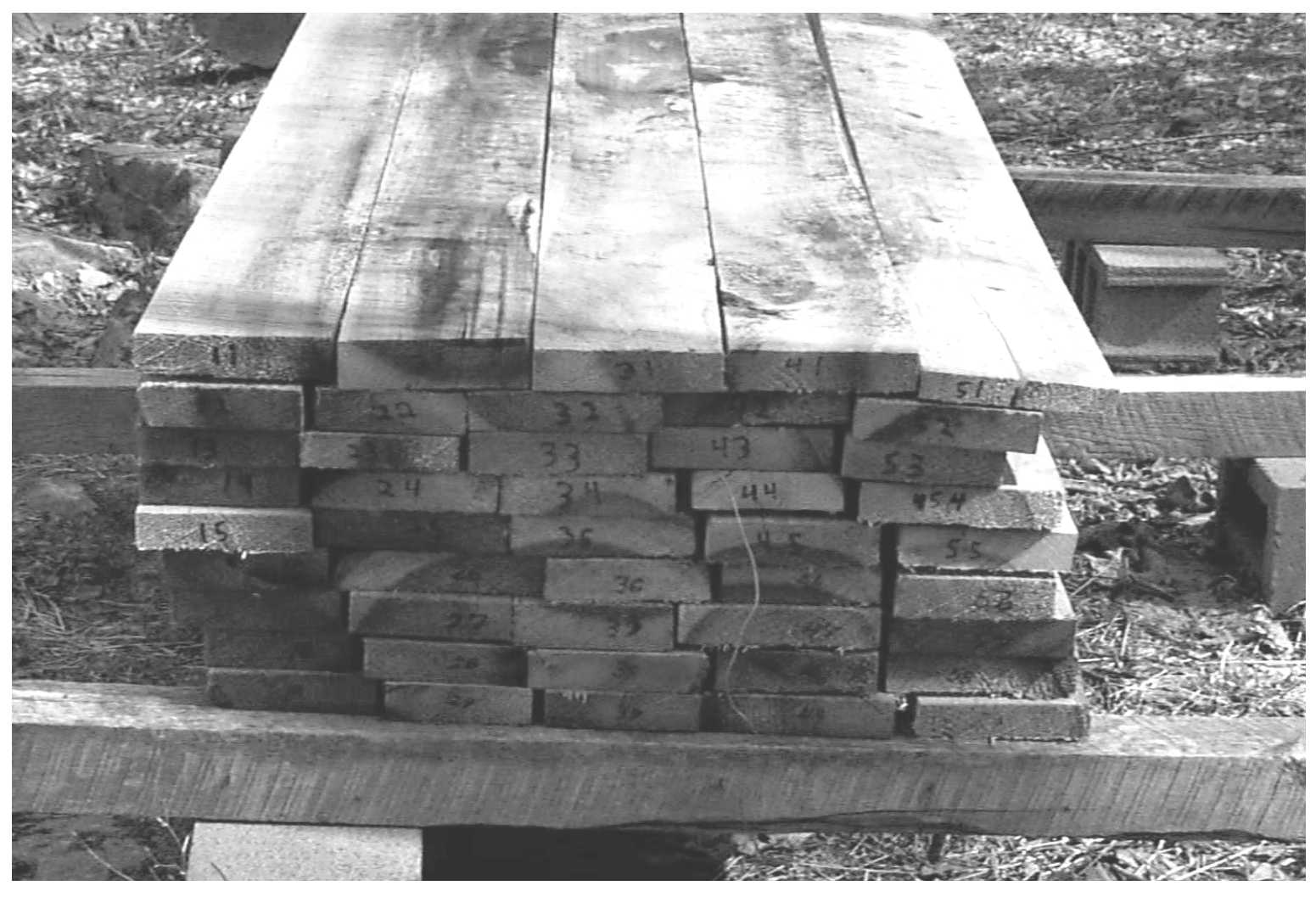


FIGURE 2. Diagram illustrates a cross-sectional view of a dead-stacked yellow-poplar lumber pile and designated sampling zone during spring 2000.

\begin{tabular}{|r|r|rr|rr|r|}
\hline 11 & 21 & & 31 & & 41 & 51 \\
\hline 12 & 22 & & 32 & & 42 & 52 \\
\hline 13 & 23 & & 33 & & 43 & 53 \\
\hline 14 & 24 & & 34 & $* *$ & 44 & 54 \\
\hline 15 & 25 & $* *$ & 35 & & 45 & 55 \\
\hline 16 & 26 & & 36 & $* *$ & 46 & 56 \\
\hline 17 & 27 & & 37 & & 47 & 57 \\
\hline 18 & 28 & & 38 & & 48 & 58 \\
\hline 19 & 29 & & 39 & & 49 & 59 \\
\hline & & & & & & \multicolumn{2}{|c|}{} \\
\hline Block & & & & & & \multicolumn{2}{|c|}{ Block } \\
\hline
\end{tabular}

FIGURE 3. Diagram illustrates a cross-sectional view of a dead-stacked yellow-poplar lumber pile and the designated sampling zone during summer 2000.

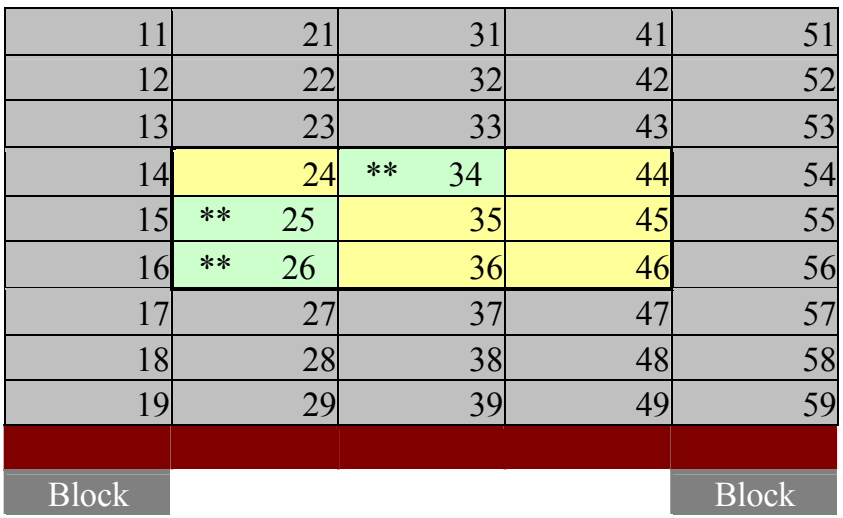

"Sampling Zone"

Unsampled Boards "Moisture Barrier"

** Board sampled 
FIGURE 4. Diagram shows an aerial view of the sampling zones for microorganisms, $\mathrm{pH}$, and moisture content on designated lumber boards during spring and summer 2000.

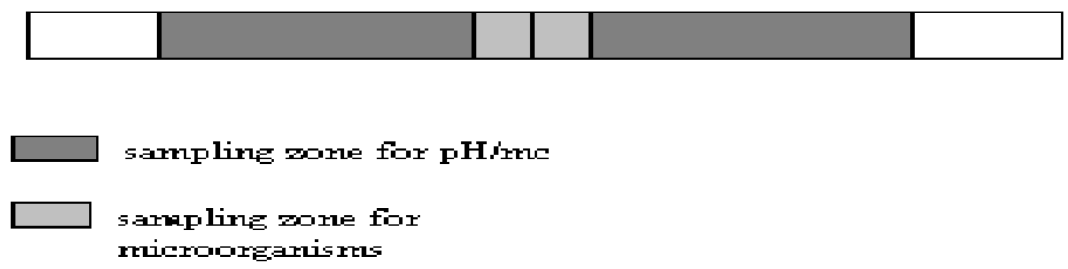

FIGURE 5. Assembled view of a modified 1/2" boring bit designed for sampling microorganism from wood.

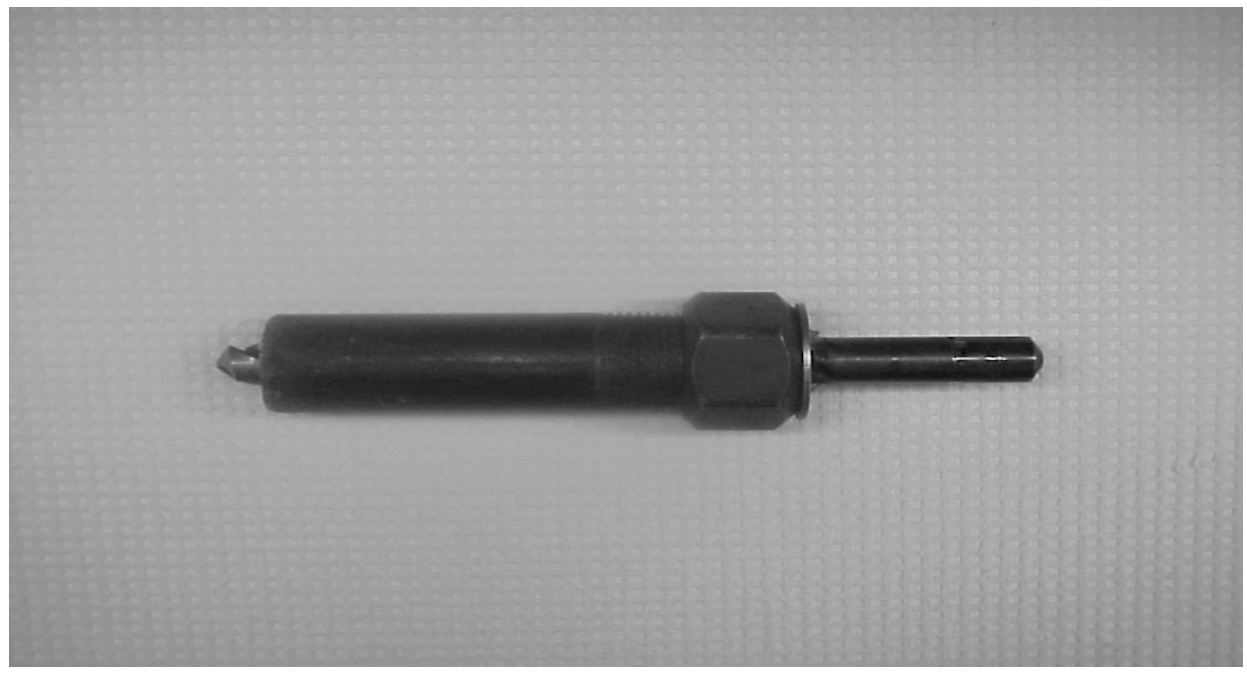


FIGURE 6. Disassembled view of a modified $1 / 2$ " boring bit designed for sampling microorganisms from wood.

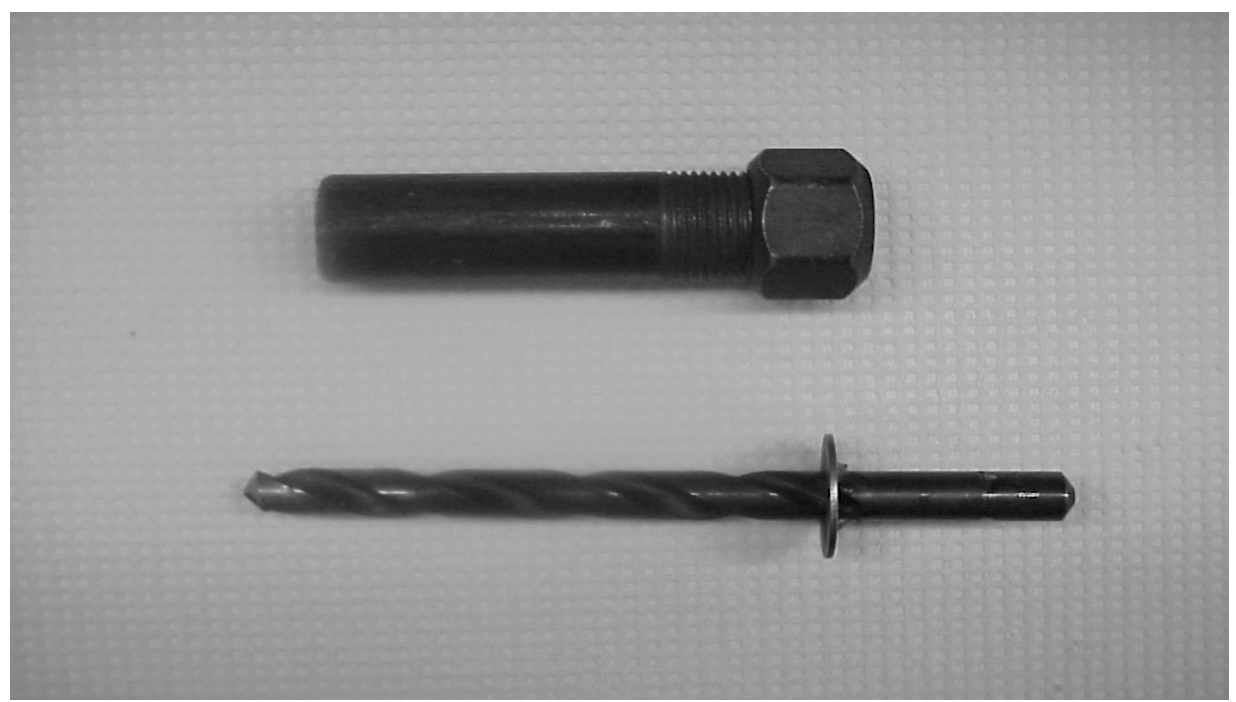

FIGURE 7. Comparison of average ambient temperature and temperature recorded within a dead-stacked lumber pile during spring and summer of 2000.

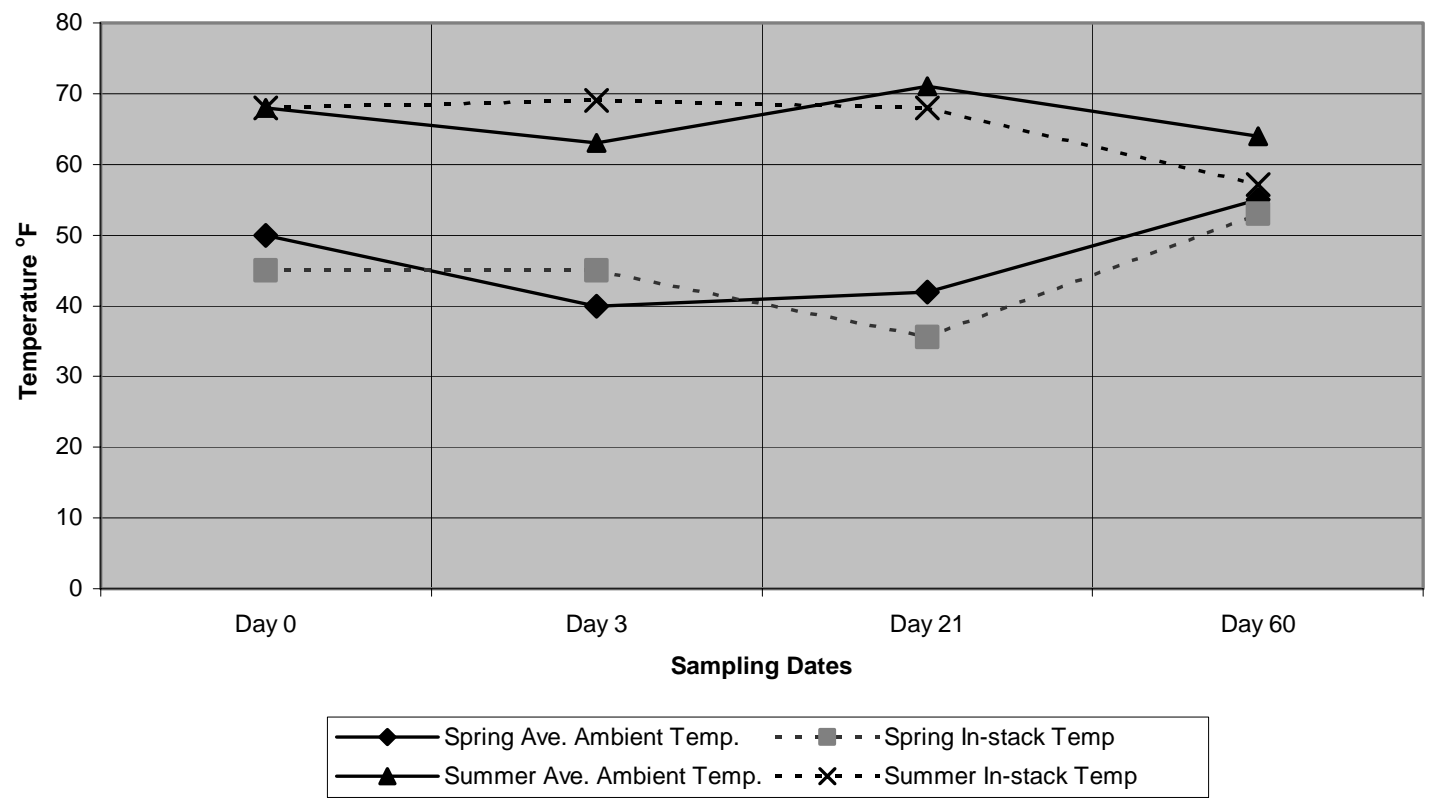


FIGURE 8. Average moisture content of lumber boards in a dead-stack during spring and summer of 2000 .

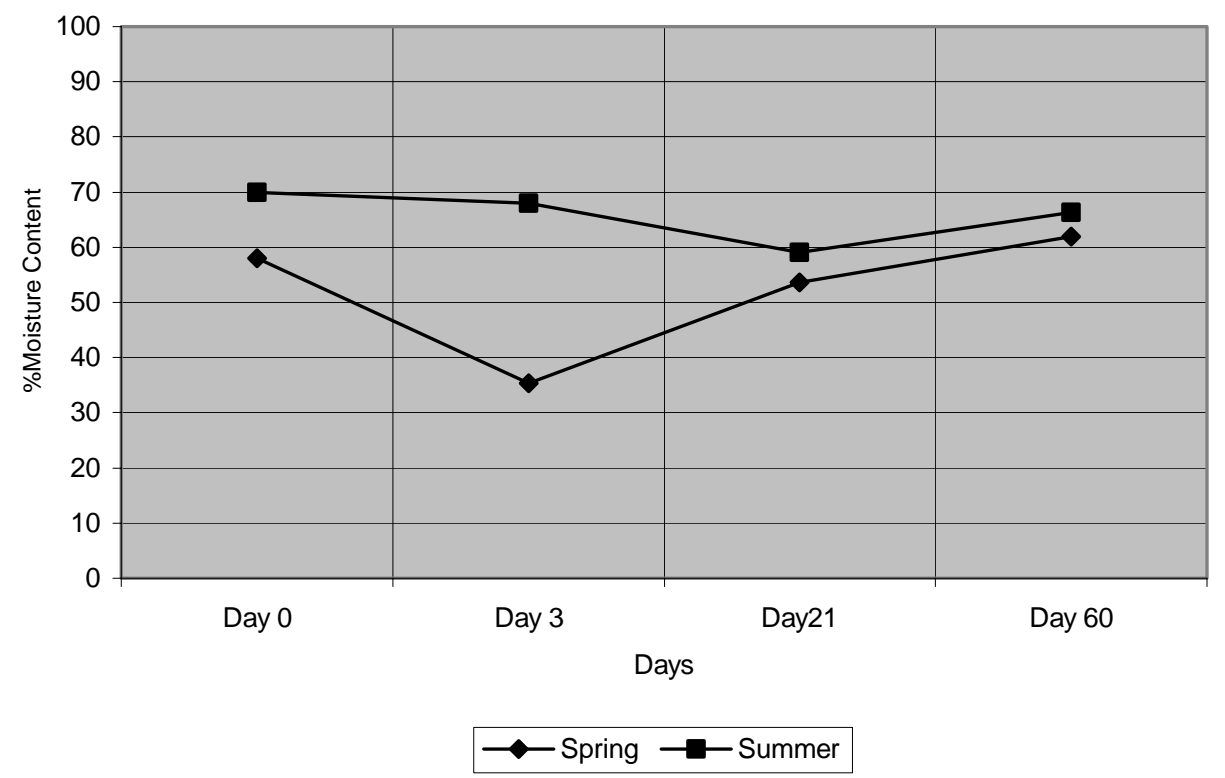

FIGURE 9. Average moisture content of sticker-stacked lumber during storage in spring of 2000.

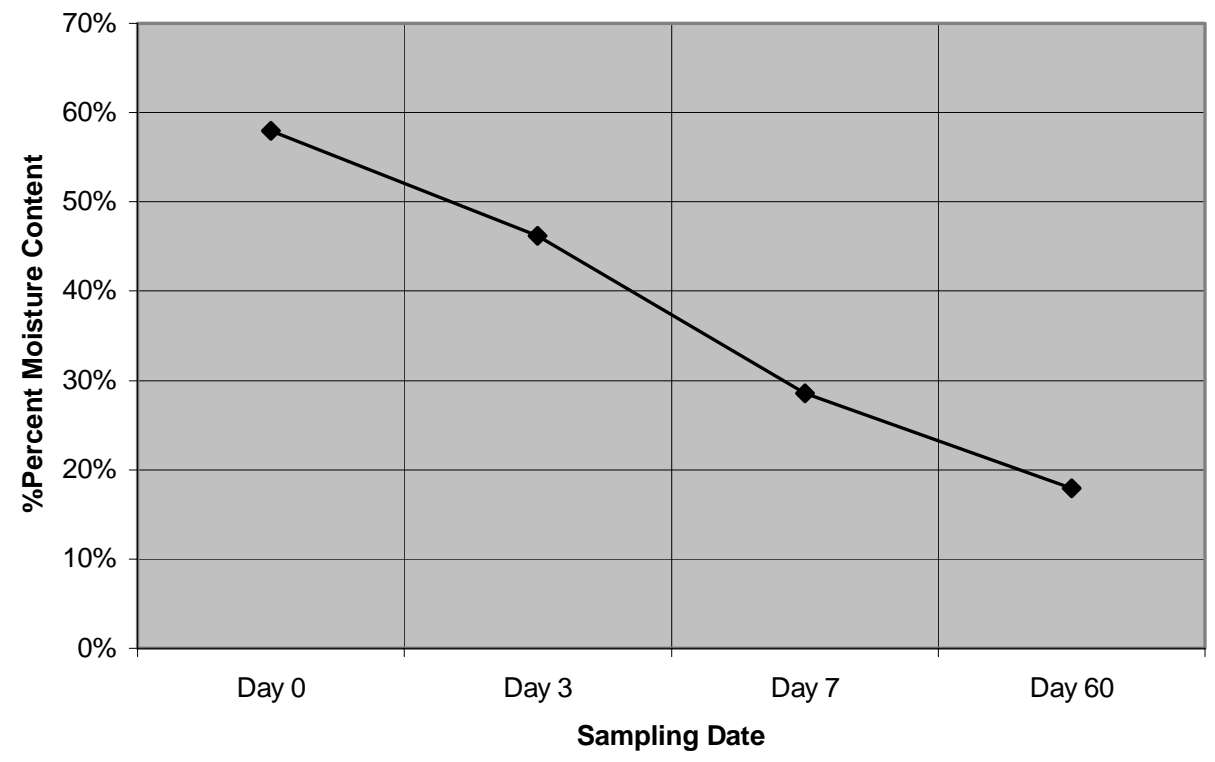


FIGURE 10. $\mathrm{pH}$ of lumber boards processed and stored in a dead-stack in spring and summer of 2000 .
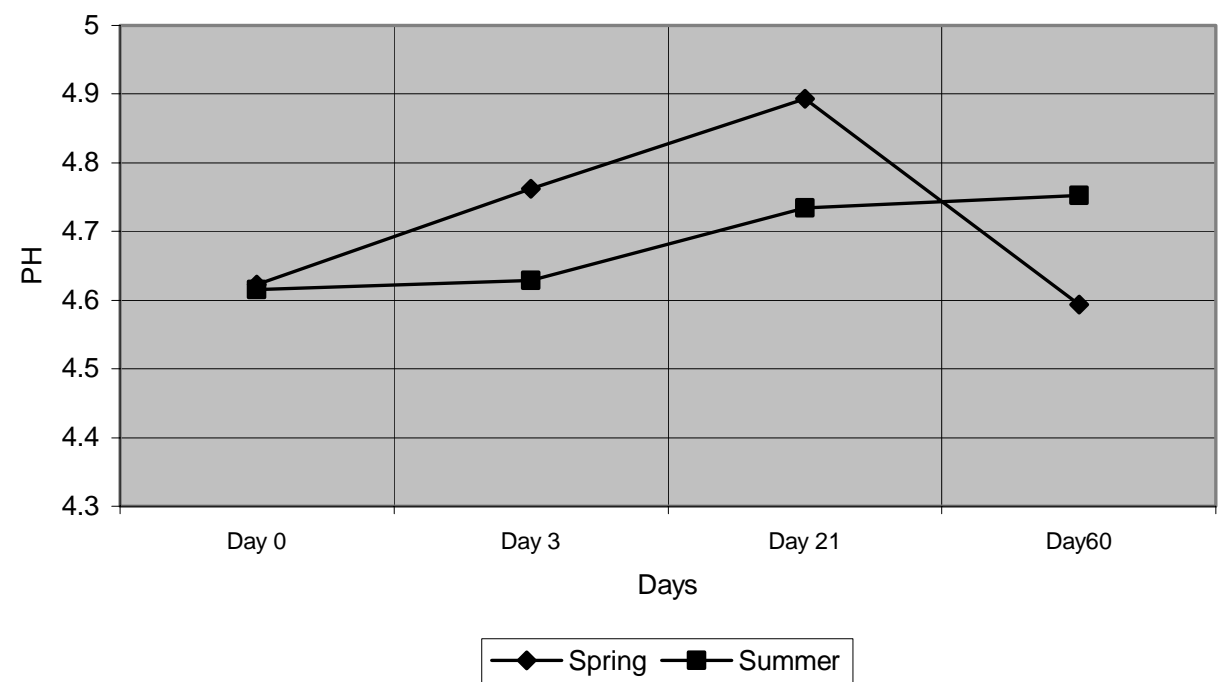

FIGURE 11. Total and average abundance of fungi isolated from freshly sawn yellowpoplar lumber after various periods of storage during spring and summer of 2000.

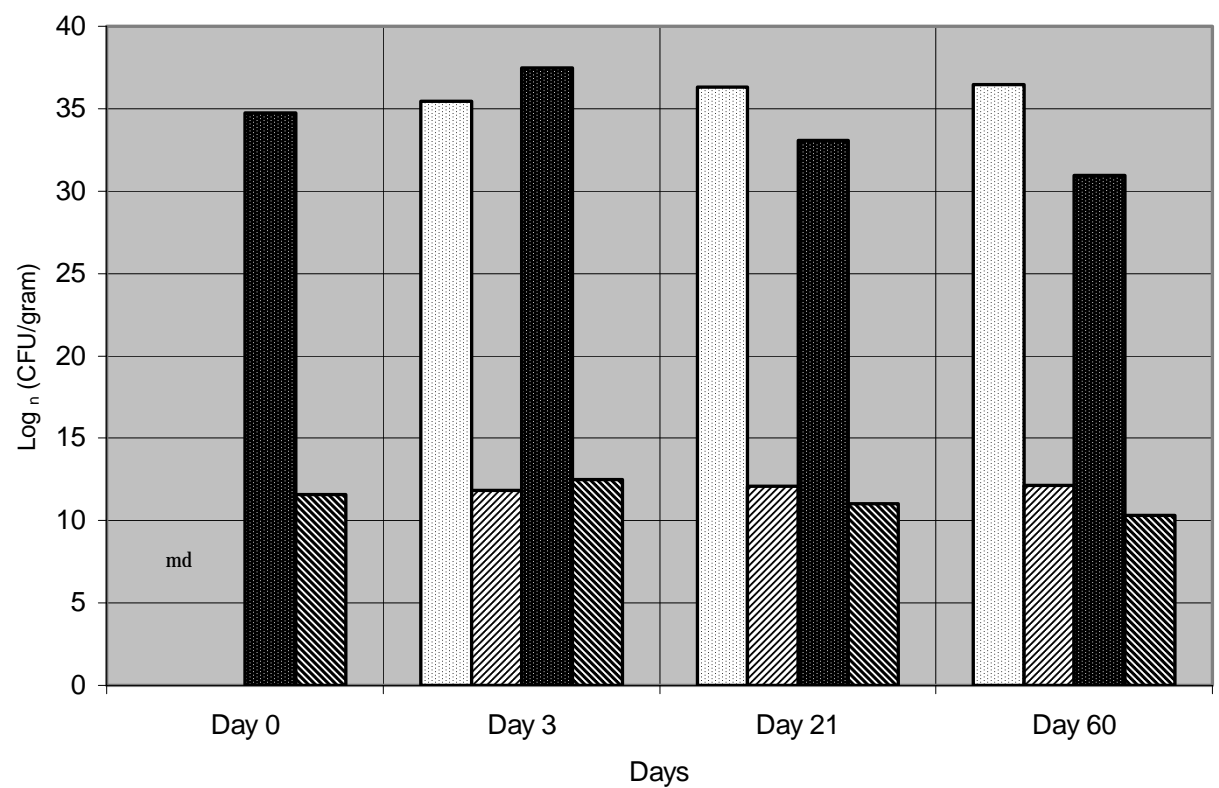

$\square$ Spring Total $\square$ Spring Ave. $\mathbf{m}$ Summer Total $\$$ Summer Ave

${ }^{\text {md }}$ Fungal abundance of Day 0 of summer was unable to be calculated due to missing sample weight. 
FigURE 12. Percent of the total abundance of microorganisms ( $\left.\log _{n} \mathrm{CFU} / \mathrm{gram}\right)$ isolated from freshly sawn yellow poplar lumber stored in a dead-stack during spring and summer of 2000

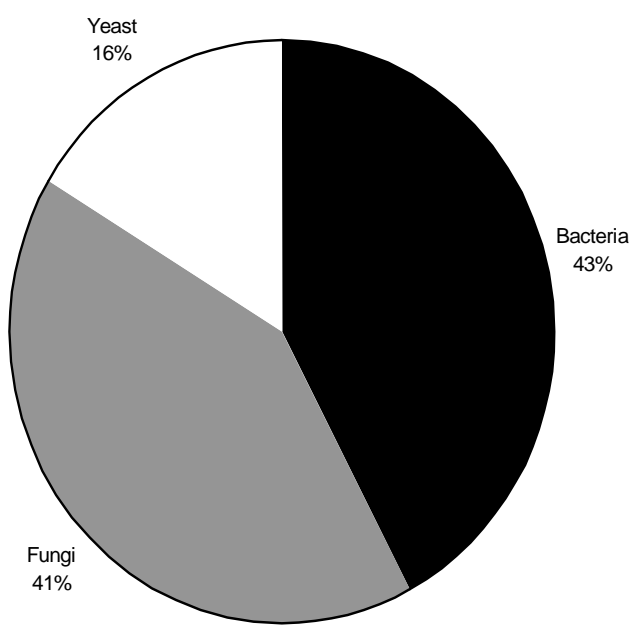

Dacteria $\square$ Fungi $\square$ Yeast 
TABLE 1. Comparison of average ambient temperature and precipitation at Hart Field Airport and West Virginia University Research Forest during spring (03/01/00 to 04/30/00).

\begin{tabular}{c|cc|cc}
\hline \multicolumn{2}{c|}{} & \multicolumn{2}{c|}{ Average Ambient Temperature $\left({ }^{\circ} \mathbf{F}\right)$} & \multicolumn{2}{c}{ Precipitation (inches) } \\
\hline Day & $\begin{array}{c}\text { Hart Field } \\
\text { Airport }\end{array}$ & $\begin{array}{c}\text { WVU Research } \\
\text { Forest }\end{array}$ & $\begin{array}{c}\text { Hart Field } \\
\text { Airport }\end{array}$ & $\begin{array}{c}\text { WVU Research } \\
\text { Forest }\end{array}$ \\
\hline 0 & 50.0 & 42.0 & 0.140 & 0.000 \\
3 & 40.0 & md & 0.000 & md \\
$0-3$ average & 41.5 & 31.5 & 0.047 & 0.220 \\
21 & 42.0 & 33.5 & 0.000 & 0.130 \\
$3-21$ average & 45.6 & 37.8 & 0.122 & 0.392 \\
60 & 55.0 & md & 0.000 & md \\
$21-60$ average & 50.7 & 38.1 & 0.143 & 0.628 \\
\hline
\end{tabular}

${ }^{\mathrm{md}}$ Data not recorded on this date at the specified test site 
TABLE 2. Climatological data recorded on each sampling date and the period between each sampling date during spring (03/01/2000 to 04/30/00) at Hart Field Airport in Morgantown, $W V$.

\begin{tabular}{|c|c|c|c|}
\hline Day & $\begin{array}{c}\text { Average Relative } \\
\text { Humidity }(\%)\end{array}$ & $\begin{array}{l}\text { Average Ambient } \\
\text { Temperature }\left({ }^{\circ} \mathrm{F}\right)\end{array}$ & $\begin{array}{l}\text { Precipitation } \\
\text { (inches) }\end{array}$ \\
\hline 0 & $39 \%$ & $50^{\circ} \mathrm{F}$ & 0.140 \\
\hline 3 & $44.8 \%$ & $40^{\circ} \mathrm{F}$ & 0.000 \\
\hline $\begin{array}{c}\text { Average Day } \\
0-3\end{array}$ & $49.4 \%$ & $41.5 \mathrm{~F}$ & 0.047 \\
\hline 21 & $86.6 \%$ & $42^{\circ} \mathrm{F}$ & 0.000 \\
\hline $\begin{array}{c}\text { Average Day } \\
3-21 \\
\end{array}$ & $60.5 \%$ & $45.6 \mathrm{~F}$ & 0.122 \\
\hline 60 & $49.9 \%$ & $55^{\circ} \mathrm{F}$ & 0.000 \\
\hline $\begin{array}{c}\text { Average Day } \\
21-60\end{array}$ & $63.7 \%$ & $50.7 \mathrm{~F}$ & 0.143 \\
\hline
\end{tabular}

TABLE 3. Climatological data recorded on each sampling date and the period between each sampling date during summer (07/21/00 to 09/19/00) at Hart Field Airport in Morgantown, $W V$.

\begin{tabular}{|c|c|c|c|}
\hline Day & $\begin{array}{c}\text { Average Relative } \\
\text { Humidity }(\%)\end{array}$ & $\begin{array}{l}\text { Average Ambient } \\
\text { Temperature }\left({ }^{\circ} \mathrm{F}\right)\end{array}$ & Precipitation (inches) \\
\hline 0 & $76 \%$ & $68 \mathrm{~F}$ & $*$ \\
\hline 3 & $90.6 \%$ & $63 \mathrm{~F}$ & 0.290 \\
\hline $\begin{array}{l}\text { Average } \\
\text { Day 0-3 }\end{array}$ & $81.8 \%$ & $65.8 \mathrm{~F}$ & 0.103 \\
\hline 21 & $78.2 \%$ & $71 \mathrm{~F}$ & 0.010 \\
\hline $\begin{array}{c}\text { Average } \\
\text { Day 3- } \\
21\end{array}$ & $80.4 \%$ & $71.8 \mathrm{~F}$ & 0.162 \\
\hline 60 & $89.9 \%$ & $64 \mathrm{~F}$ & 0.000 \\
\hline $\begin{array}{c}\text { Average } \\
\text { Day 21- } \\
60\end{array}$ & $81.8 \%$ & $67.7 \mathrm{~F}$ & 0.060 \\
\hline
\end{tabular}

*No data was recorded at this date for precipitation. 
TABLE 4. Summary of the comparison of the monthly average ambient temperature at Hart Field Airport and West Virginia University Research Forest during 2000.

\begin{tabular}{|l|l|l|}
\hline Month & $\begin{array}{l}\text { Hart Field Airport } \\
\text { (HFA) }\end{array}$ & $\begin{array}{l}\text { University } \\
\text { (UF) }\end{array}$ \\
\hline March & $46.0^{\circ} \mathrm{F}$ & $42.0^{\circ} \mathrm{F}$ \\
\hline April & $51.3^{\circ} \mathrm{F}$ & $45.8^{\circ} \mathrm{F}$ \\
\hline July & $69.8^{\circ} \mathrm{F}$ & ${ }^{\mathrm{I}} \mathrm{MI}$ \\
\hline August & $69.5^{\circ} \mathrm{F}$ & ${ }^{\mathrm{I}} \mathrm{MI}$ \\
\hline September & $63.5^{\circ} \mathrm{F}$ & ${ }^{\mathrm{I}} \mathrm{MI}$ \\
\hline
\end{tabular}

${ }^{1} \mathrm{MI}=$ missing information due to equipment malfunction

TABLE 5. Fungal abundance per sampling period during spring and summer of 2000.

\section{Fungal Abundance}

\begin{tabular}{|c|c|c|c|c|}
\hline \multirow{3}{*}{$\begin{array}{c}\text { Days of } \\
\text { Sampling }\end{array}$} & \multirow{2}{*}{\multicolumn{2}{|c|}{ Spring }} & \multirow{2}{*}{\multicolumn{2}{|c|}{ Summer }} \\
\hline & & & & \\
\hline & $\begin{array}{c}\log _{\mathrm{n}} \\
\text { CFU/gram } \\
\end{array}$ & CFU/gram & $\begin{array}{c}\log _{n} \\
\text { CFU/gram } \\
\end{array}$ & CFU/gram \\
\hline Day 0 Total & $\mathrm{m}$ & $\overline{\mathrm{m}}$ & 34.7 & $9.2 \mathrm{E}+05$ \\
\hline Day0 Average & $\mathrm{m}$ & $\mathrm{m}$ & 11.6 & $3.1 \mathrm{E}+05$ \\
\hline Day 3 Total & 35.5 & $4.6 \mathrm{E}+05$ & 37.5 & $1.5 \mathrm{E}+06$ \\
\hline Day3 Average & 11.8 & $1.5 \mathrm{E}+05$ & 12.5 & $5.1 \mathrm{E}+05$ \\
\hline Day 21 Total & 36.3 & $1.1 \mathrm{E}+06$ & 33.1 & $2.7 \mathrm{E}+05$ \\
\hline Day21 & 12.1 & $3.6 \mathrm{E}+05$ & 11.0 & $9.1 \mathrm{E}+04$ \\
\hline \multicolumn{5}{|l|}{ Average } \\
\hline Day 60 Total & 36.5 & $1.2 \mathrm{E}+06$ & 30.9 & $5.0 \mathrm{E}+05$ \\
\hline Day60 & 12.15 & $3.9 \mathrm{E}+05$ & 10.3 & $1.7 \mathrm{E}+05$ \\
\hline \multicolumn{5}{|l|}{ Average } \\
\hline Total & 108.3 & $2.7 \mathrm{E}+06$ & 136.2 & $2.7 \mathrm{E}+06$ \\
\hline Average & 36.1 & $9.0 \mathrm{E}+05$ & 34.1 & $6.8 \mathrm{E}+05$ \\
\hline
\end{tabular}

${ }^{\mathrm{m}}$ Fungal abundance could not be calculated due to missing sample weight. 
TABLE 6. Fungi isolated and identified from yellow-poplar lumber during spring and summer of 2000 at four sampling dates.

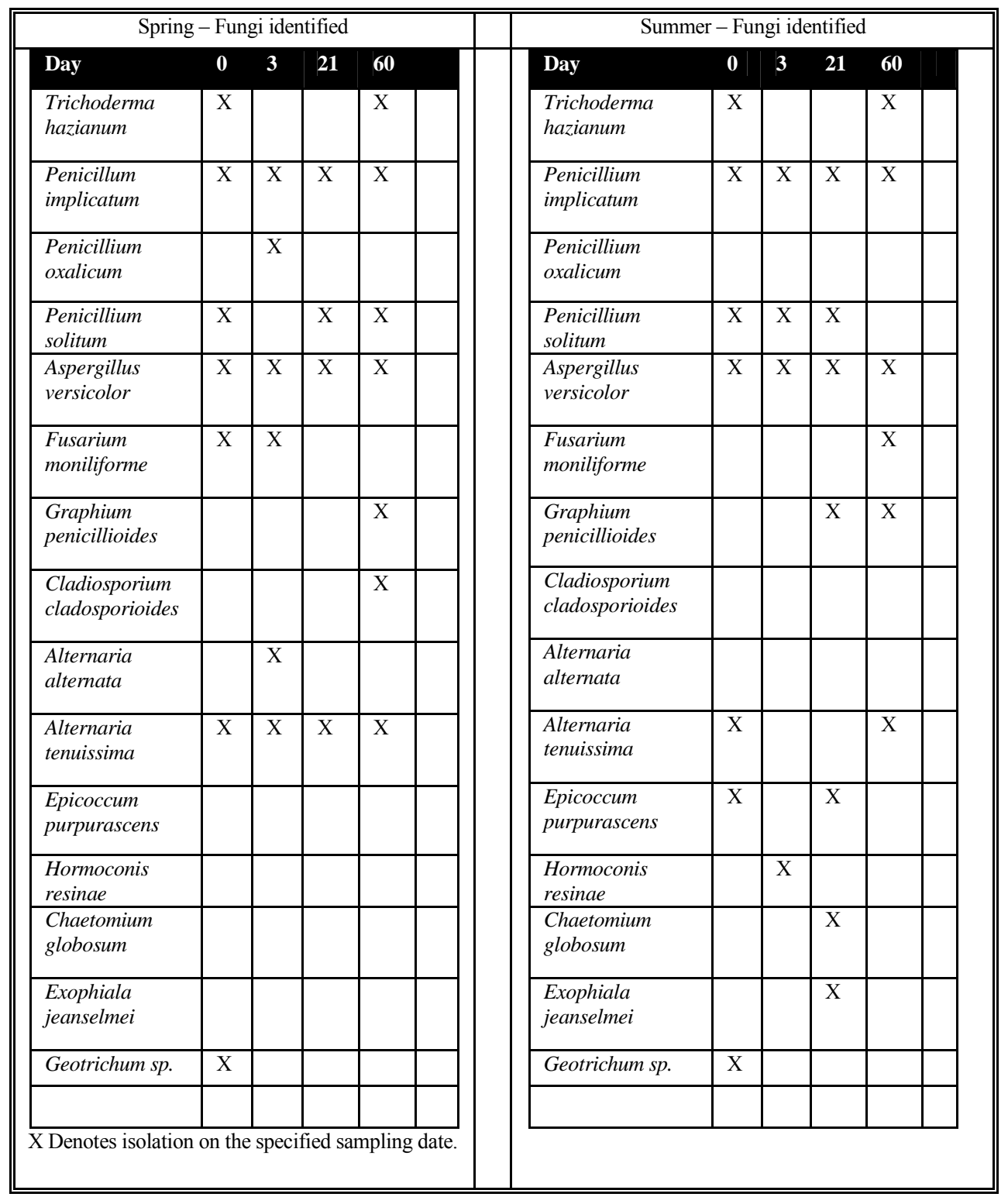


TABLE 7. Percent of fungal isolates obtained from yellow-poplar lumber after 60 days of storage during spring and summer 2000.

\begin{tabular}{|c|c|c|c|}
\hline \multirow{2}{*}{ Fungi } & \multicolumn{3}{|c|}{ Percent of total fungal isolation (\%) } \\
\hline & Spring & Summer & Total Study \\
\hline $\mathrm{F} 1^{*}$ & 1.0 & 0.0 & 0.7 \\
\hline Penicillium implicatum & 29.9 & 29.3 & 29.7 \\
\hline P. solitum & 6.9 & 4.9 & 6.32 \\
\hline P. oxalicum & 0.3 & 0.0 & 0.2 \\
\hline Graphium penicillioides & 4.9 & 4.9 & 4.9 \\
\hline Cladiosporium cladosporioides & 0.3 & 0.0 & 0.2 \\
\hline Trichoderma hazianum & 1.6 & 3.3 & 2.1 \\
\hline F145* & 0.3 & 0.0 & 0.2 \\
\hline Aspergillus versicolor & 12.2 & 20.3 & 14.5 \\
\hline $\mathrm{F} 10^{*}$ & 0.3 & 0.0 & 0.2 \\
\hline Alternaria alternata & 2.0 & 0.0 & 1.4 \\
\hline A. tenuissima & 2.0 & 4.1 & 2.6 \\
\hline F15* & 1.0 & 3.3 & 1.6 \\
\hline Epicoccum purpurascens & 0.0 & 1.6 & 0.5 \\
\hline $\mathrm{F} 17^{*}$ & 0.3 & 1.6 & 0.7 \\
\hline Hormoconis resinae & 0.0 & 0.8 & 0.2 \\
\hline F19* & 18.4 & 6.5 & 15.0 \\
\hline Fusarium moniliforme & 1.0 & 8.1 & 3.0 \\
\hline Geotrichum sp. & 0.3 & 0.8 & 0.5 \\
\hline Chaetomium globosum & 0.0 & 0.8 & 0.2 \\
\hline Exophiala jeanselmei & 0.0 & 3.3 & 0.9 \\
\hline Unidentified fungi & 17.8 & 6.5 & 14.5 \\
\hline Total & 100.0 & 100.0 & 100.0 \\
\hline
\end{tabular}


TABLE 8. Percent of fungal isolates obtained from yellow-poplar lumber on four sampling dates in spring and summer of 2000.

\begin{tabular}{|c|c|c|c|c|c|c|c|c|}
\hline \multirow{4}{*}{ Fungi } & \multicolumn{8}{|c|}{ Percent of Total Fungal Isolations } \\
\hline & \multicolumn{8}{|c|}{ Sampling days in Spring and Summer } \\
\hline & \multicolumn{2}{|c|}{0} & \multicolumn{2}{|c|}{3} & \multicolumn{2}{|c|}{21} & \multicolumn{2}{|c|}{60} \\
\hline & Spring & Summer & Spring & Summer & Spring & Summer & Spring & Summer \\
\hline $\mathrm{F} 1^{*}$ & 0.0 & 0.0 & 0.0 & 0.0 & 0.0 & 0.0 & 3.0 & 0.0 \\
\hline Penicillium implicatum & 21.7 & 24.4 & 29.3 & 42.9 & 44.8 & 27.3 & 26.3 & 24.1 \\
\hline P. solitum & 10.1 & 6.7 & 0.0 & 7.1 & 1.7 & 4.5 & 13.1 & 0.0 \\
\hline P. oxalicum & 0.0 & 0.0 & 1.2 & 0.0 & 0.0 & 0.0 & 0.0 & 0.0 \\
\hline Graphium penicillioides & 0.0 & 0.0 & 0.0 & 0.0 & 0.0 & 9.1 & 15.2 & 13.8 \\
\hline Cladiosporium cladosporioides & 0.0 & 0.0 & 0.0 & 0.0 & 0.0 & 0.0 & 1.0 & 0.0 \\
\hline Trichoderma hazianum & 7.2 & 4.4 & 0.0 & 0.0 & 0.0 & 0.0 & 0.0 & 6.9 \\
\hline F145* & 1.4 & 0.0 & 0.0 & 0.0 & 0.0 & 0.0 & 0.0 & 0.0 \\
\hline Aspergillus versicolor & 8.7 & 33.3 & 23.2 & 14.3 & 12.1 & 22.7 & 5.1 & 3.4 \\
\hline F10* & 0.0 & 0.0 & 3.7 & 0.0 & 0.0 & 0.0 & 0.0 & 0.0 \\
\hline Alternaria alternata & 0.0 & 0.0 & 7.3 & 0.0 & 0.0 & 0.0 & 0.0 & 0.0 \\
\hline A. tenuissima & 2.9 & 2.2 & 1.2 & 0.0 & 1.7 & 0.0 & 2.0 & 13.8 \\
\hline F15* & 0.0 & 2.2 & 1.2 & 7.1 & 0.0 & 4.5 & 2.0 & 0.0 \\
\hline Epicoccum purpurascens & 0.0 & 2.2 & 0.0 & 0.0 & 0.0 & 4.5 & 0.0 & 0.0 \\
\hline F17* & 1.4 & 0.0 & 0.0 & 10.7 & 0.0 & 0.0 & 0.0 & 0.0 \\
\hline Hormoconis resinae & 0.0 & 0.0 & 0.0 & 3.6 & 0.0 & 0.0 & 0.0 & 0.0 \\
\hline F19* & 7.2 & 8.9 & 19.5 & 10.7 & 36.2 & 4.5 & 14.1 & 0.0 \\
\hline Fusarium moniliforme & 1.4 & 0.0 & 2.4 & 0.0 & 0.0 & 0.0 & 0.0 & 34.5 \\
\hline Geotrichum sp. & 1.4 & 2.2 & 0.0 & 0.0 & 0.0 & 0.0 & 0.0 & 0.0 \\
\hline Chaetomium globosum & 0.0 & 0.0 & 0.0 & 0.0 & 0.0 & 4.5 & 0.0 & 0.0 \\
\hline Exophiala jeanselmei & 0.0 & 0.0 & 0.0 & 0.0 & 0.0 & 18.2 & 0.0 & 0.0 \\
\hline Unidentified fungi & 36.2 & 13.3 & 11.0 & 3.6 & 3.4 & 0.0 & 18.2 & 3.4 \\
\hline Total & 100.0 & 100.0 & 100.0 & 100.0 & 100.0 & 100.0 & 100.0 & 100.0 \\
\hline
\end{tabular}

* Denotes fungi differentiated by colony morphology but unable to be identified. 


\title{
Chapter 4
}

Microbial ecology of freshly sawn yellow-poplar (Liriodendron tulipifera L.) lumber in two seasons: Part II. Bacteria.

\author{
Mark Mikluscak \\ Graduate Student \\ and \\ Benjamin E. Dawson-Andoh \\ Associate Professor \\ Division of Forestry \\ West Virginia University \\ Morgantown, WV. 26506-6125
}

\begin{abstract}
This paper reports on the bacteria that were isolated from freshly-sawn (green) yellowpoplar lumber during the initial 60 days of storage in spring and summer of the year 2000. The total abundance of bacteria comprised $43 \%$ of the total population of microorganisms sampled and 14 different species of bacteria were identified. Bacillus sp was the predominant species and accounted for $42 \%$ of the total bacteria positively identified. Abundance of bacteria on each sampling date increased with increasing average ambient temperature in the period leading up to sampling.
\end{abstract}

\section{INTRODUCTION}

In part one of this study (Chapter 3), which reported on the occurrence of fungi on green yellow-poplar lumber, the cause of discoloration of freshly sawn lumber and the ecological 
basis for developing a biological control agent as an alternative method for preventing this discoloration were reviewed. Although bacteria have been evaluated by several authors as potential agents for biological control of decay, mold, and sapstain fungi on wood, adequate information on their role and identity as part of the colonizing microflora of green lumber remains absent (Benko 1986, 1987,1988,1989; Benko and Highley 1990a, 1990b; Payne et al. 2000).

Bacteria are a component of the microflora that colonizes wood (Greaves and Levy 1968; Levy 1975). Although fungi predominantly cause the discoloration of wood, bacteria occupy a sizeable portion of the substrate and the colonizing microflora. The presence of bacteria in several wood elements such as parenchyma cells, pit membranes, resin ducts, and pit chambers is well documented (Ellwood and Ecklund 1959; Verrall 1939; Greaves 1968). However, the role of bacteria and their interaction with other microflora during the colonization of wood has been less studied (Henningsson 1967).

Rossell et al. (1973) reported that microbial interaction may be antagonistic, synergistic or mutualistic. Bacteria have the ability to fix nitrogen, degrade or modify chemical compounds in wood, and provide nutritional by-products necessary for the growth of other microorganisms. Also, they can synergistically interact with other microorganisms such as fungi or yeast (Fries 1938). Although bacteria can serve as both primary and secondary colonizers of wood, depending on the period of their appearance during the colonization process, synergistic interaction between bacteria and fungi usually occurs at the end of bacterial succession. Interaction between bacteria and fungi occurring at the beginning of bacterial colonization usually leads to an antagonistic relationship, which results in the suppression or inhibition of fungal growth. A case in point is the report of Rossell et al. (1973) which indicates that if bacteria were transferred to the substrate before or at the same time as decay fungi, the development of the fungi was always reduced. Bacillus sp in particular, is antagonistic to the fungus Ceratocystis sp (Asante and Neal 1964). 
Although, the time of introduction of each microorganism into the successional pattern is important, interaction between bacteria and other colonizing microflora on wood also may be mediated by physical factors such as $\mathrm{pH}$, temperature, production of antibiotics, and competition for nutrients. Most, if not all, of these factors are influenced by geographic location and seasonal effects. Gray (1958) states that the $\mathrm{pH}$ of wood changes as water is extracted. The $\mathrm{pH}$ of a substrate also may be modified through the production of organic acids or the liberation of ammonia by colonizing microorganisms (Asante and Neal 1964; Highley and Lutz 1970). Bacteria such as Bacillus and Lactobacillus sp produce oxalic acids during growth (Asante and Neal 1964). Asante and Neal (1964) also reported that bacteria isolated from yellow-poplar lumber used nitrogen compounds to produce ammonia which increased wood $\mathrm{pH}$. Temperature also influences the interaction between microorganisms. Henningsson (1967) reports that "temperature has a decisive affect on the development of this interaction phenomena." In addition to interaction, the type and distribution of communities of microorganisms is determined principally by temperature (Shields 1969). Temperature not only influences colonizing microorganisms but also affects the antagonistic activity of bacteria on agar and wood (Henningsson 1967). Secondary metabolites or antibiotics production by microorganisms influences both their interaction and colonization of wood. Under favorable temperature conditions, wood bacteria can produce antibiotic substances and inhibit the growth of fungi (Henningsson 1967). Although many bacteria have the ability to produce antibiotics, the production of antibiotics or secondary metabolites has not been clearly demonstrated on wood in situ. Overall, the competition for nutrients is recognized as one of the major influential factors affecting microbial interaction and subsequent growth. Through utilization or the fixation of nitrogen, bacteria can influence the interaction of colonizing microorganisms by altering the available nutrients. All these traits make bacteria good potential biological control agents.

Elucidation of microbial types colonizing wood and their nature is an important key to the future development of environmentally compatible methods of protecting and processing wood. Therefore, isolation and identification of bacteria colonizing yellow-poplar lumber 
in this study represents an important step to the understanding of the microbial ecology of green hardwood lumber. It will also facilitate the development of ecological based biological control strategy. This strategy has been used with some measure of success in the control of postharvest diseases of fruits and vegetables (Janisiewicz 1988, 1994, 1996; Janisiewicz et al. 1992; Janisiewicz and Bors 1995; Lindow 1991, 1994; Wilson and Lindow 1994).

This paper reports on the identity, frequency, and diversity of bacteria that colonize green sawn yellow-poplar lumber.

\section{MATERIALS AND METHODS}

\section{Lumber}

\section{Lumber stack}

Yellow-poplar trees randomly selected in the West Virginia University Research were felled and bucked into logs, one week prior to their conversion to lumber. The green lumber was dead-stacked (no stickers) to form a lumber pile measuring approximately $2.5^{\prime}$ (width) and 1.6' (height). This was done in both spring and summer of 2000. The lumber pile was placed on 4 x 4 " billets, which rested on cinder blocks to produce a clearance of 1.5-2.0' above the ground (Figure 1). To eliminate the anticipated increase in plant growth under the lumber stack during summer, a plastic sheet was placed underneath the cinder blocks prior to set-up of the lumber stack. During each season, lumber boards were randomly selected from the sampling zone in the lumber pile on four different days: Day 0, 3,21 , and 60 as described previously. Details of the sampling procedure can be found in Chapter 3.

\section{Lumber appearance}

During sampling, the general appearance of the entire lumber pile and each individual lumber board was recorded. The entire stack was taken down and rebuilt after sampling. 


\section{Sampling of lumber boards}

Randomly selected lumber boards within the sampling zone were sampled for bacteria, moisture content, and $\mathrm{pH}$. Details of the protocol are described in Chapter 3.

\section{Physical factors}

\section{Climate}

Climatological data was recorded at two sites: Hart Field Airport and the WVU Research Forest, located in the Morgantown, WV area. Data recorded at the Hart Field Airport was provided by the National Climatological Data Center (NCDC). Since some of the data at WVU Research Forest was missing due to equipment failure, NCDC data was used for the primary comparison of atmospheric conditions during the periods of this study.

\section{Temperature within the lumber stack}

A temperature probe was placed between rows four and five in the center of the lumber pile to record in-stack lumber temperature. The in-stack temperature was recorded only on each sampling date.

\section{Moisture content and $\mathrm{pH}$ measurement}

Wood samples for moisture content and $\mathrm{pH}$ determinations were taken from the same lumber boards that were sampled for bacteria with an increment borer as described in Chapter 3. Moisture contents of samples were determined as per ASTM D 4442-92 Standard (2001). Wood sample $\mathrm{pH}$ was determined as per a modified US Forest Products Laboratory procedure using a Corning $\mathrm{pH} /$ ion analyzer 350 and a Corning flat-surface combination electrode at $25^{\circ} \mathrm{C}$ (Moore and Johnson 1997).

\section{Bacteria}

\section{Isolation of bacteria}

Wood samples evaluated for bacteria were taken with a modified boring drill bit

(Dutkiewicz et al. 1992). A Detailed description of the boring bit is provided in Chapter 3. 
Protocol for bacterial isolation was per Dutkiewicz et al. (1992). Pre-weighed wood samples were placed in $45 \mathrm{ml}$ sealable vials containing $20 \mathrm{ml}$ of sterile phosphate-buffered saline solution amended with $0.1 \%(\mathrm{v} / \mathrm{v})$ Tween 80 . Using a rotary shaker, the vials and their contents were shaken for one hour at $100 \mathrm{rpm}(\mathrm{s})$. Ten-fold serial dilutions $\left(10^{0}\right.$ to $10^{-}$ ${ }^{5}$ ) were prepared as per Pepper et al. (1995). To determine total aerobic bacteria, $100 \mu 1$ of each dilution were spread on duplicate plates of nutrient agar (Difco, Inc. 2000). During summer sampling, $4 \mathrm{mg} / \mathrm{L}$ of benomyl (50\% active ingredient) was added to the nutrient agar media to reduce fungal growth. Inoculated petri-plates were incubated at $28{ }^{\circ} \mathrm{C}$ for a minimum of 48 hours.

At the end of the incubation period, individual colonies were counted and re-isolated onto sterile nutrient agar plates to establish pure colonies. Isolated bacteria were segregated based on growth behavior on agar, microscopic cellular characteristics, and colony morphology (Dutkiewicz et al. 1992; Schmidt 1985). Colony counts were made after a period of 2-3 days for bacteria (Dandurand and Knudsen 1997). Bacterial abundance initially was recorded as Colony Forming Units (CFU) per unit gram of wood and then transformed to the natural $\log \left(\log _{\mathrm{n}} \mathrm{CFU} /\right.$ gram) to reduce variability (Dutkiewicz et al. 1992).

\section{Identification of Bacteria}

Isolated bacteria were identified by Dr. Ellen Dickstein (University of Florida, Dept. of Plant Pathology) using the "Microbial Identification System" (MIDI, 1999). In this protocol, isolates were inoculated on Trypticase soy broth agar and incubated at $28{ }^{\circ} \mathrm{C}$ for 24 hours. From each isolate, fatty acids were extracted and their composition determined by gas-chromatography analysis as per the MIDI protocol (MIDI Inc., 1999). Resulting fatty acid profiles were compared to that of known standard bacteria contained in TSBA40 library, the newest version of the library developed by MIDI Inc (1999). Each isolate was assigned a Similarity Index Number (SIN) after a search of the MIDI database to obtain the best match. The SIN expresses how closely the fatty acid composition of the unknown bacterial isolates compares with the mean fatty acid composition of the strain used to create 
the library entry listed as its match (Sasser 1997). The SIN is also an expression of the relative distance of the unknown bacteria from the population mean of the best match library entry. As each fatty acid varies from the mean percentage, the SIN will decrease in proportion to the cumulative variance between the composition of the unknown bacterial isolates and the library entry (Sasser 1997). General guidelines for the Similarity Index Number (SIN) indicate that strains with SIN values of 0.5 or higher and a separation of 0.1 between the first and second choices are acceptable matches (Rhodes et al. 1998, MIDI system 1999). Further, Rhodes et al. (1998) recommend that a SIN less than 0.5, and /or a separation of less than 0.1 between the SIN of the first two choices indicates a closely related species. A case in point is a SIN between 0.3 to 0.5 with good separation between the top two choices, which may be a good match but indicate an atypical strain. Values lower than 0.3 indicate that a particular species is not in the database and the closest related species are given.

\section{DATA ANALYSIS}

\section{Characterization of microbial community}

All identified bacteria isolates were characterized by two species diversity indices: Species Richness (SR) and Species Evenness (SE). Species diversity is one important property of biological communities (Krebs 1999). This property, which is measured using general methods, is an index of the importance of a species in a community assuming that all species are equally different (Krebs 1999).

SE was determined using the Berger-Parker Dominance Index (BPDI). BPDI provides no information on the identity of species present in the sample and is defined as the proportion of all individuals that are of the most abundant species (Brown 1985). The BPDI was calculated for each season.

SR represents the number of species in a sample (Brown 1985). This diversity index, as with the BPDI, was applied only to identified bacteria. SR omits the evenness of abundance and is completely objective if the sample is random. In this study, SR was computed for 
each sampling period and for each season in total. The results illustrate the number of species identified on each sampling date and provides a general comparison of the species in contrasting seasons.

\section{Statistical analysis}

Significant differences between sampling dates or seasons for each physical factor (with the exception of precipitation) was determined by the SAS GLM procedure for type III ANOVA test.

\section{RESULTS AND DISCUSSION}

\section{Lumber Appearance}

Lumber discolorations were initially observed as a pink to reddish coloration on Days 21 and 60 in both spring and summer. Many of the identified bacteria isolated during this study have been reported to produce colored pigments on synthetic media under appropriate conditions. Flavobacterium sp, Pseudomonas sp, Xanthomonas sp, and Micrococcus sp produce pigments of a wide range of colors (Pelczar and Reid 1972). In particular, species of Bacillus, Flavobacterium, Psuedomonas, and Micrococcus, produce reddish pigments on agar (Pelczar and Reid 1972; Buchanan and Gibbons 1974). Additionally, Bacillus subtilis, B. cereus, and Psuedomonas aeruginosa also produce red pigments in culture (Buchanan and Gibbons 1974). Although bacteria with the ability to produce pigments were isolated during this study, fungi are primarily the known causal agents of lumber discoloration. To date, no studies have shown bacteria to cause wood discoloration

A darker or blackish discoloration appeared on the lumber boards on Day 60 of summer. Although this stain could be attributed to fungal growth, Alcaligenes $\mathrm{sp}, B$. subtilis, and $B$. cereus, also produce dark colored pigments (brown or black) in vitro (Buchanan and Gibbons 1974; Pelczar and Reid 1972). All lumber stains observed during this study occurred outside the sampling zone and no tests were performed to determine if discoloration was caused by bacterial growth. 


\section{Physical factors}

Physical factors including temperature, moisture content, available nutrients, and $\mathrm{pH}$ impact the growth and distribution of microorganism. Physical factors that were monitored during this study were ambient relative humidity, temperature, and precipitation. Within the stack, $\mathrm{pH}$, moisture content, and in-stack temperature also were recorded. Climatological data used for comparison during this study was averaged between consecutive sampling periods to gain a clearer picture of the conditions of the entire period leading up to sampling rather than on specific sampling dates.

\section{Precipitation}

Average precipitation recorded at Hart Field during spring ranged from 0.05 to 0.14 inches per day. The greatest amount of precipitation was observed in the period between Day 21 and Day 60 sampling. During summer, the average precipitation ranged from 0.06 to 0.16 inches per day. The highest amount of precipitation was observed between Day 3 and Day 21 during summer sampling. Although moisture is a requirement for microbial growth, no relationship was determined between the changes in precipitation and bacterial abundance during this study.

\section{Relative humidity}

Relative humidity at Hart Field Airport ranged from 33.3-95.9\% and 60.6-97.0\% per day in spring and summer, respectively. Statistically, no significant difference $(\mathrm{P}<0.05)$ was detected in the relative humidity between season or sampling period and no correlation could be associated between the changes in relative humidity and bacterial abundance.

\section{$p H$}

The $\mathrm{pH}$ of yellow-poplar has been reported as $5.43 \pm 0.21$ and 4.50 and show reasonable agreement with the results (4.6-4.9) obtained in this study (Koch 1985; Highley and Lutz 1970). An increase in $\mathrm{pH}$ was observed from 4.6 (Day 0) to 4.9 (Day 21), followed by a decrease on Day 60 (4.6) during spring. During summer, average $\mathrm{pH}$ increased at each 
sampling date from 4.6 (Day 0) to 4.8 (Day 60). No statistically significant difference $(\mathrm{P}>0.05)$ was detected in the $\mathrm{pH}$ value of each lumber board between seasons and sampling dates.

Although most bacteria have an optimum $\mathrm{pH}$ of seven or higher, some bacteria thrive at a pH below seven (Henningsson 1967). Bacillus subtilis and B. macerans exhibit optimum growth in the $\mathrm{pH}$ range of 5.5-8.5 and 2-8, respectively (Buchanan and Gibbons 1974). The abundance of bacteria recorded in this study suggests their ability to grow at a lower $\mathrm{pH}$ than previously reported (Henningsson 1967). However, no direct relationship between $\mathrm{pH}$ and bacterial abundance could be discerned. Hence, wood $\mathrm{pH}$ may be one of the least important influencing factors for bacterial growth.

\section{Moisture Content}

Average moisture content of lumber ranged from $35-62 \%$ and $59-70 \%$ in spring and summer, respectively. Initially, moisture content in summer decreased from $70 \%$ on Day 0 to $59 \%$ on Day 21 and then increased to $66 \%$ on day 60 . The observed elevated moisture contents can be attributed to increase in precipitation and relative humidity.

Bacteria preferentially colonize wood under moist conditions, such as wood chip piles, living trees, water-cooling towers, and logs stored under water. Bacteria occur predominantly in logs and bolts stored in ponds (Highley and Lutz 1970; Ellwood and Ecklund 1959). Above a moisture content of $40 \%$, wood becomes increasingly anaerobic and therefore more suitable for bacterial colonization (Rayner and Todd 1979). Since no correlation was found between bacterial abundance and moisture content of lumber boards, it is suggested that moisture content was adequate for bacterial growth. In addition, other factors such as ambient temperature, substrate composition, and time influence microbial growth (Pasanen et al. 1992). 


\section{Temperature within the lumber stack}

In-stack lumber temperatures were generally lower than that of the ambient air. They ranged from 35.6 to $53.0^{\circ} \mathrm{F}$ and from 57.2 to $69.0^{\circ} \mathrm{F}$ in spring and the summer respectively (Figure 2). In contrast to ambient temperature, they exhibited very little variation perhaps due to the insulating properties of wood. Although a statistically significant difference $(\mathrm{P}<0.05)$ was detected in the in-stack lumber temperature and in bacterial abundance between seasons, no relationship could be discerned between the changes that occurred at each individual sampling period. It is suggested that the variations in bacterial abundance on sampling dates are influenced by the fluctuating ambient temperatures rather than the instack temperature.

Growth, distribution, and interaction of microorganisms is influenced by temperature (Shields 1969; Humphrey and Siggers 1933; Henningsson 1967). Optimum temperature for growth of bacteria normally ranges from $25-35^{\circ} \mathrm{C}$. However, some bacteria do exhibit a wide temperature range for growth. Bacillus macerans, for example, has a temperature range of $-5^{\circ} \mathrm{C}$ to $75^{\circ} \mathrm{C}$ for vegetative growth (Buchanan and Gibbons 1974).

It is suggested that a more meaningful comparison of the ambient temperature could be made if the entire period between each sampling period was investigated, rather than the temperature recorded on each individual sampling date. The average ambient temperature calculated between consecutive sampling dates, in spring, increased from $41.5^{\circ} \mathrm{F}$ (between Day 0 and Day 3) to $50.7^{\circ} \mathrm{F}$ (between Day 21 and 60). The total abundance of bacteria followed this same trend, increasing throughout the spring from 29.1 ( $\log _{n}$ CFU/gram) on Day 3 to 43.0 ( $\log _{\mathrm{n}} \mathrm{CFU} / \mathrm{gram}$ ) on Day 60. The average ambient temperature between consecutive sampling dates during the summer increased from $65.8^{\circ} \mathrm{F}$ (between Days 0 and 3) to $71.8^{\circ} \mathrm{F}$ (between Days 3 and 21) and declined thereafter. During this same period, the abundance of bacteria increased from Day 0 to Day 21 and declined thereafter (Figure 3). Overall, the greatest abundance of bacteria occurred on Day 60 in spring and Day 21 in summer (Figure 3). This coincides with the highest values calculated for average ambient 
temperature, which occurred in the period leading up to sampling, during spring (Day 21 to Day 60) and summer (Day 3 to Day 21).

In total, average bacterial abundance in spring was lower than in summer, indicating the effect of temperature or seasonal conditions. The total abundance of bacteria in spring and summer were 110.1 and $139.8 \log _{n}(\mathrm{CFU} /$ gram), respectively (Table 1). A type III test of the Least Square Means (LSM) using the GLM Procedure (SAS) indicated a statistically significant difference $(\mathrm{P}>0.05)$ in bacterial abundance between spring and summer, as well as a significant difference $(\mathrm{P}>0.05)$ between the average ambient temperatures recorded on the sampling dates during these two seasons.

\section{Bacteria}

True and Tyron (1967) reported that bacteria were isolated from nearly $2 / 3$ of yellowpoplar wood samples. Bacteria also are isolated from decaying and discolored hardwoods more frequently than all other microflora (McCreary et al. 1965). This observation agrees with the results of this study. In total, bacteria accounted for $43 \%$ of the entire population of isolated microorganisms. Per sampling date, bacteria constituted the greatest percent of the total abundance of microorganisms isolated on Day 21 (51\%) and Day 60 (45\%) of spring (Figure 4). In summer, bacteria represented the greatest portion of the total community sampled on Day 0 (41\%) and Day 60 (44\%) (Figure 4).

Out of a total of forty-six representative isolated bacteria, eleven isolates could not be reisolated and the rest were submitted for identification by the MIDI System. Twenty-one were acceptably identified by the MIDI system. Fatty acid profiles for thirteen isolates (38\%) did not match MIDI library (SIN of less than 0.3 , or a separation of less than 0.1 between the first two database matches) and were therefore, not identified. All identified bacteria were primarily gram-positive. In total, fourteen species representing seven genera were positively identified (Table 2). Bacillus was the predominant bacterial genus identified and accounted for nearly $42 \%$ of the total bacteria identified (Figure 5). Previous studies have reported similar results indicating that the most frequently isolated bacteria 
from wood belonged to the genus Bacillus (Ellwood and Ecklund 1959; Henningsson 1967). Species of Bacillus that were identified in this study included: B. cereus, B. mycoides, B. pumilis, B. subtilis, B. globisporius and B. circulans. The genus Bacillus is a free-living, aerobic/ facultative anaerobic, heterotrophic, non-photosynthetic, unicellular organism that produces endospores; exhibits great diversity in the organisms they take on; and secretes low molecular weight acids (Skerman 1959; Buchanan and Gibbons 1974). Other bacteria commonly isolated from wood in the past include Pseudomonas sp, Xanthomonas sp, Micrococcus sp, and Sarcina sp (McCreary et al 1965; Lutz et al. 1966; Ellwood and Ecklund 1959).

Since bacterial isolation in this study was periodic, it cannot be assumed that all bacteria colonizing yellow-poplar lumber boards were either isolated or identified (Kang and Morrell 2000). Butcher (1968) states that the isolation of microorganisms in a study is often a function of the sampling technique used. In addition, sampling procedure, incubation conditions, and growth media, also may limit the potential for isolation of specific microorganisms (Kang and Morrell 2000). Kang and Morrell (2000) go on to state that in some cases, identified microorganisms represent opportunistic colonizers that occur only occasionally.

A list of bacteria identified during this study are given in Table 2. On Day 0 of spring, three species of the genus Bacillus were identified: B. mycoides, B. cereus, and B. simplex. A related species of Bacillus, Paenibacillus macerans, also was identified on this date. In summer, Alcaligenes xylosoxydans, and Stenotrophomonas maltophilia were identified on Day 0.

Bacillus globisporous and Paenibacillus pabuli were identified on Day 3 in spring. Although bacterial abundance was relatively high (36.0 $\left.\log _{n} \mathrm{CFU} / \mathrm{gram}\right)$ compared to the same day in summer, none were positively identified. 
On Day 21 of spring, only Bacillus pumilis was identified. However, in summer the second highest total abundance of bacteria ( $40.3 \log _{n}$ CFU/gram) and greatest diversity of bacterial species was recorded. Identified bacteria included: $P$. putida, P. aeruginosa, Chryseobacterium meningosepticum, S. maltophilia, Kocuria kristinae, A. xylosoxydans, and B. pumilis.

Bacillus subtilis, P. pabuli, and Rahnella aquatilis were identified in spring on Day 60 . Bacteria belonging to two genera, Bacillus (B. mycoides and B. cereus) and Stenotrophomonas (S. maltophila) were recorded on Day 60 in summer.

Pseudomonas sp, which was isolated several times, is commonly found in soils and water (Pelczar and Reid 1972; Buchanan and Gibbons 1974). While some species reduce nitrates to ammonia to cause an increase in $\mathrm{pH}$ (Pelczar and Reid 1972), others produce acids that reduce $\mathrm{pH}$ of wood (Buchanan and Gibbons 1974). The genus Pseudomonas is nutritionally versatile with the ability to utilize a large variety of organic compounds as an energy source (Buchanan and Gibbons 1974). Pseudomonas putida and P. aeruginosa can utilize up to 80 different organic compounds for growth (Buchanan and Gibbons 1974) and may explain the freuquency of their isolation in this study.

Species of Bacillus rarely have distinctive habitats and may be the reason for their abundance in this study (Buchanan and Gibbons 1974). Some species secrete low molecular weight acids while others produce antibiotics when sporulating (Asante and Neal 1964). Some Bacillus sp lysis cells of other microorganisms (Buchanan and Gibbons 1974). These are important attributes of a biological control agent.

Bacillus circulans, which was isolated on Day 60 of summer, is a very unusual species. The entire colony is motile and migrates over media in a "watch - spring course"(Skerman 1959). Bacillus circulans is also a weakly cellulose degrading microbe (Buchanan and Gibbons 1974). This ability may negatively impact the residual strength of wood. 
Bacillus macerans (Paenibacillus macerans), which was isolated on Day 0 of spring produce acids and gases from carbohydrates (Skerman 1959). Bacillus macerans also decomposes pectin as well as plant polysaccharides and exhibits growth at a $\mathrm{pH}$ range of 3.8-4 (Buchanan and Gibbons 1974).

Bacillus subtilis also decomposes pectin and polysaccharides in plants and its spores are normally widespread in nature (Buchanan and Gibbons 1974).

\section{Species Richness (SR) and Evenness (SE)}

SR for isolated bacteria in spring and summer were four and sixteen, respectively. This diversity index shows that a much greater number of species were present during summer sampling. This shows that the number of species also increases with ambient temperature as observed for bacterial abundance. The highest SR, eleven, occurred on Day 21 of the summer, an indication of the presence of eleven species of bacteria. This also represents the greatest number of bacteria identified on any of the individual sampling dates. It also coincided the highest average ambient temperatures which further supports the earlier suggested relationship between bacterial growth and ambient temperature.

BPDI for spring and summer on average were 0.27 and 0.24 , respectively. These values represent the proportion of bacteria that were of the most abundant species. The similarity in these numbers suggest that bacteria abundance during both spring and summer were even. A higher BPDI indicates greater proportion of isolated bacteria belonging to the most abundance species.

\section{CONCLUSION}

1. This study provides information on the type, occurrence, and abundance of bacteria isolated on green yellow-poplar lumber.

2. Bacteria accounted for the greatest portion of the total microorganisms sampled in this study and therefore are predominant colonizers of dead-stacked green yellow-poplar lumber. 
3. Bacterial abundance was directly related to the average ambient temperature in the period leading up to the sampling date and bacterial abundance in spring and summer were significantly different $(\mathrm{P}>0.05)$.

4. The genus Bacillus had the greatest number of species representatives and accounted for $42 \%$ of the total bacteria identified.

5. Gram-positive aerobic bacteria were the most frequently identified bacteria.

6. Fatty acid profiles for $38 \%$ of bacterial isolates did not match MIDI Library and were unable to be identified.

\section{ACKNOWLEDGEMENTS}

The authors thank Dr. Daniel Panaccione and Mr. Mark Double for their multitude of assistance; Dr. William Thayne and Dr. Mark Brown for statistical support; Jeffrey Slahor, George Mikluscak for technical assistance; Dr. Ellen Dickstein for the identification of bacterial isolates; and Robert Driscole West Virginia University Research Forest Manager.

\section{REFERENCES}

American Society for Testing And Materials. (ASTM) 2001. ASTM Standard D 4442-92. Standard test methods for direct moisture content measurement of wood and wood-base materials. West Conshohocken, PA. p 510-515.

AsANTE, G. S., AND A. L. NEAL. 1964. Characterization of fungistatic substances produced by a Bacillus antagonistic to Ceratocystis ulmi. Phytopathology 54(7): 819-822.

BENKO, R. 1986. Protection of wood against the blue stain. Int. Cong. of IUFRO. Reference \# 18. Ljubljana. Yugoslavia.

----------. 1987. Antagonistic effects of some mycorrhizal fungi as biological control of blue-stain. Int. Res. Group on Wood Preserv. Stockholm, Sweden. IRG/WP/1314.

1988. Bacteria as possible organisms for biological control of blue-stain. Int. Res. Group on Wood Preserv. Stockholm, Sweden. IRG/WP/1339. 1989. Bacterial control of blue-stain on wood with Pseudomonas cepacia 6253. laboratory and field test. Int. Res. Group. Stockholm, Sweden. IRG/WP/1380. 
AND T. L. Highly. 1990A. Selection of media on screening interaction of wood attacking fungi and antagonistic bacteria. 1. Interaction on agar. Mater. Orgon. 25(3): 161-171.

---------., AND T. L. HIGHLY. 1990B. Selection of media on screening interaction of wood attacking fungi and antagonistic bacteria. 2. Interaction on wood. Mater. Orgon. 25(3): 171-180.

BROWN, M. W. 1985. A Fortran program to calculate several diversity indices. USDA Res. Serv., ARS-27: 24.

BuChanAN, R. E., AND N. E. GiBBOns, (eds). 1974. Bergey's manual of determinative bacteriology. $8^{\text {th }}$ edition. Williams \& Wilkins Co. Waverly Press, Inc. Baltimore, MD. p $115-268$.

ButCHER, J.A. 1968. The ecology of fungi infecting untreated sapwood of Pinus radiata. Can. J. Bot. 46: 1577-1589.

Dandurand, L. C., AND G. R. KnUdSEn. 1997. Manual of Environmental Microbiology. ASM Press. Washington, D.C.

Dutkiewicz, J., C. Kwapiszewski, S. Olenchock, AND D. Lewis. 1992. Compact drill sampler for the quantitation of microorganisms in wood. United States Patent: 50378553:1-12.

ElLwOOD, E. L., AND B. A. ECKLUND. 1959. Bacterial attack of pine logs in pond storage. Forest Prod. J. 9(9): 283-292.

GRAY, V. R. 1958. The acidity of wood. Journal of the institute of wood science. 11: 58-64.

Greaves, H., AND J. F. LeVy. 1968. Microbial associations in the deterioration of wood under long-term exposure. Pages 429-443 in A. H. Walters and J. J. Elphick, eds. Biodeterioration of Materials. Microbiological and Applied Aspects. Elsevier, Amsterdam.

HENNINGSSON, B. 1967. Interaction between microorganisms found in Birch and Aspen pulpwood. Stud. For. Suec. 53: 1-31.

Highley, T. L., AND J. F. LuTZ. 1970. Bacterial attack in water-stored bolts. Forest Prod. J. 20(4): 43-44. 
HuMPhREY, C. J., AND P. V. SigGERS. 1933. Temperature relationships of wood destroying fungi. J. of Agric. Res.47: 997-1008.

JANSIEWICZ, W.J. 1988. Biocontrol of postharvest diseases of apples with antagonistic mixtures. Phytopathology 78: 194-198.

---------. 1994. Nutritional characterization of natural microflora of apple and its possible role in selection of biocontrol agents. Phytopathology 84: 1152.

---------. 1996. Ecological diversity, niche overlap, and coexistence of antagonists used in developing mixtures for biological of postharvest diseases of apples. Phytopathology 86: 473.

---------. AND B. BORS. 1995. Development of a microbial community of bacterial and yeast antagonists to control wound-invading post-harvest pathogens to fruits. Appl. and Environ. Microbiol. 61(9): 3261-3267.

---------., J. Usall, and B. Bors. 1992. Nutritional enhancement of biocontrol of blue mold on apples. Phytopathology 82: 1364.

KANG, S., AND J. J. MoRRELL. 2000. Fungal colonization of Douglas-fir sapwood lumber. Mycologia 92(4): 609-615.

KoCH, P. 1985. Utilization of hardwoods growing on southern pine sites. USDA Forest Serv., Agric. Handbook \#605 3710. U.S. Govt. Print. Off. Washington, D.C. p 453.

KREBS, C. J. 1999. Ecological Methodology. $2^{\text {nd }}$ edition. Addison-Welsey Educational Publishers, Inc. Menlo Park, CA. p 410-446.

LEVY, J. F. 1975. Colonization of wood by fungi. Pages 16-23 in W. Liese, ed. Biological transformation of wood by microorganisms. Springer. Berlin.

Lindow, S. E. 1991. Determinants of epiphytic fitness in bacteria. Page 295 in J. H. Andrews and S. S. Hirano, eds. Microbial ecology of leaves. Springer-Verlag. New York.

1994. Epiphytic fitness determinants in bacteria. Page 29 in D. D. Bills and S. D. Kung, eds. Proceedings of the fourth international symposium, biotechnology and plant protection. World Scientific Publishing Co. Pte. Ltd. Singapore. River Edge, New Jersey. 
LuTZ, J. F., C. G. DunCAN, AND T.C. SCHEFFER. 1966. Some effect of bacterial action on rotary cut southern pine veneer. Forest Prod. J. 16(8): 23-28.

McCreary, M., B. Coesenza, And A. L. Shigo. 1965. Bacteria isolated from decays and discoloration in northern hardwoods. Phytopathology 55(1): 129-130.

Moore, W. E., AND D. B. Johnson. 1997. Procedures for the analysis of wood and wood products. USDA. Forest Prod. Lab. For. Serv. Madison, WI. p 1-4.

Pasanen, A. L., T. Juutinen, M. J. Jantunen, And P. Kalliokoski. 1992. Occurrence and moisture requirements of microbial growth in building materials. Int. Biodet. and Biodegr. 30: 273-283.

Pepper, I. L., C. P. Gerbe, And J. W. Brendecke. 1995. Environmental Microbiology. Academic Press, San Diego, CA. p 27.

RaYNeR, A. D. M., AND N. K. TODD. 1979. Population and community structure and dynamics of fungi in decaying wood. Advan. Botan. Res. 7: 333-420.

Rhodes, A. N., J. W. Urbance, H. Youga, H. Corlew-Newman, C. A. Reddy, M. J. KLUG, J. M. TIEDJE, AND D. C. FISHER. 1998. Identification of bacterial isolates obtained from intestinal contents associated with 12,000-year-old Mastodon remains. Appl. and Environ. Microbiol. February: 651-658.

Rossell, S. E., E. G. M. ABBotT, AND J. F. LeVy. 1973. Bacteria and wood. A review of the literature relating to the presence, action and interaction of bacteria in wood. Journal of the wood institute of wood science. No.32, 6(2):28-35.

SASSER, M. 1997. Identification of bacteria by gas chromatography of cellular fatty acids. MIDI, Technical note \#101, May 1990 (Revised 1997). p 1-7.

SCHMIDT, O. 1985. Occurrence of microorganisms in the wood of Norway spruce trees from polluted sites. Eur. J. Forest Path. 15: 1-10.

SHIELDS, J. K. 1969. Microflora of eastern Canadian wood chip piles. Mycologia 61(6): 1165-1168.

SkERMAN, V. B. D. 1959. A guide to the identification of the genera of bacteria with methods and digests of generic characteristics. The Williams \& Wilkins Co. Baltimore, MD. $p 115$. 
True, R. P., AND E. H. Tyron. 1967. Butt decay in yellow poplar sprouts in West Virginia. West Virginia University Agricultural experiment station. Bulletin 541T.

VERRALL, A. F. 1939. Relative importance and seasonal prevalence of wood staining fungi in the southern United States. Phytopathology 29: 1031-1051.

WiLSON, M., AND S. E. LINDOW. 1994. Ecological similarity and coexistence of epiphytic ice-nucleating Pseudomonas syringae strains and nonice-nucleating biological control agent. Appl. Environ. Microbiol. 60: 3128. 
FIGURE 1. Cross sectional view of dead-stacked yellow-poplar lumber.

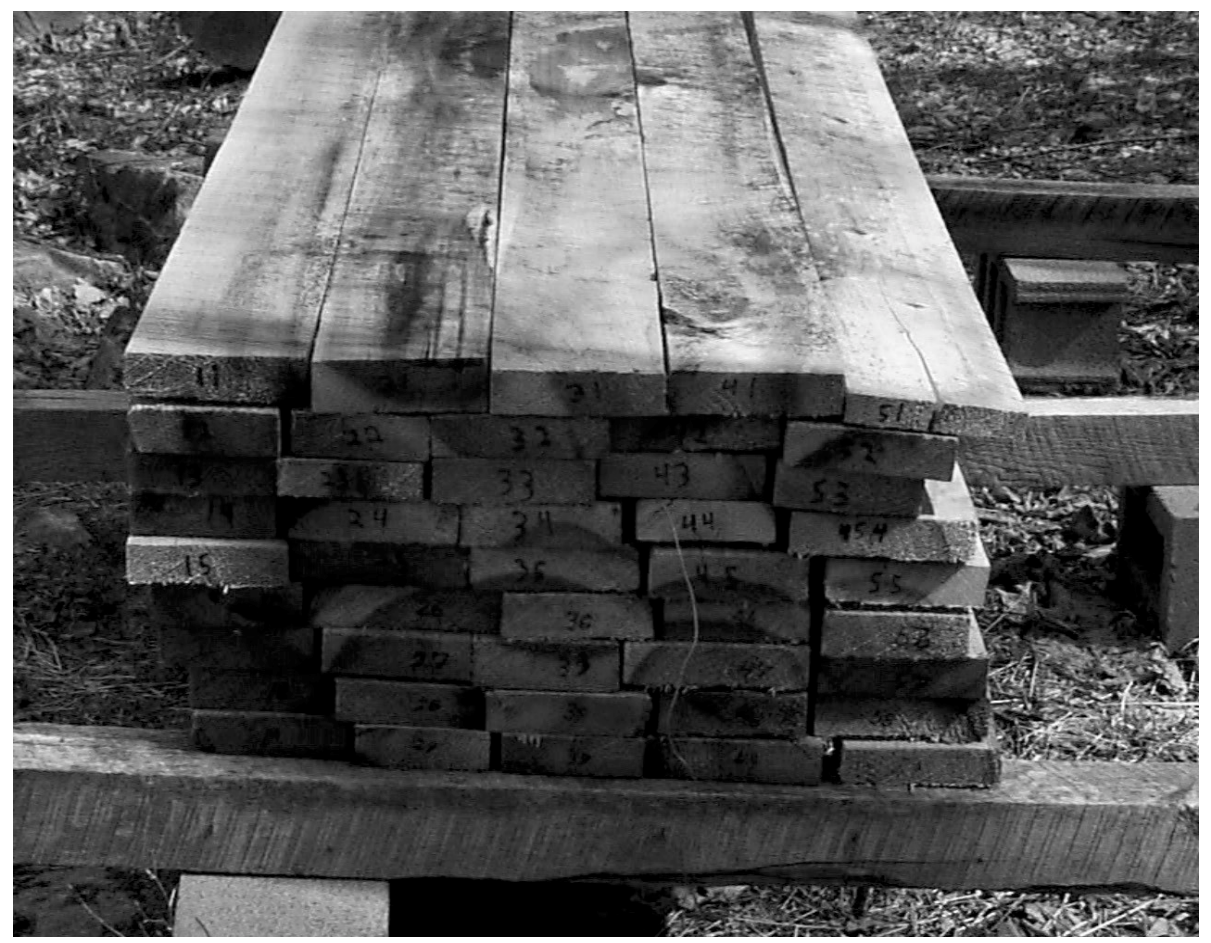

FIGURE 2. Comparison of ambient and in-stack temperature during spring and summer of 2000

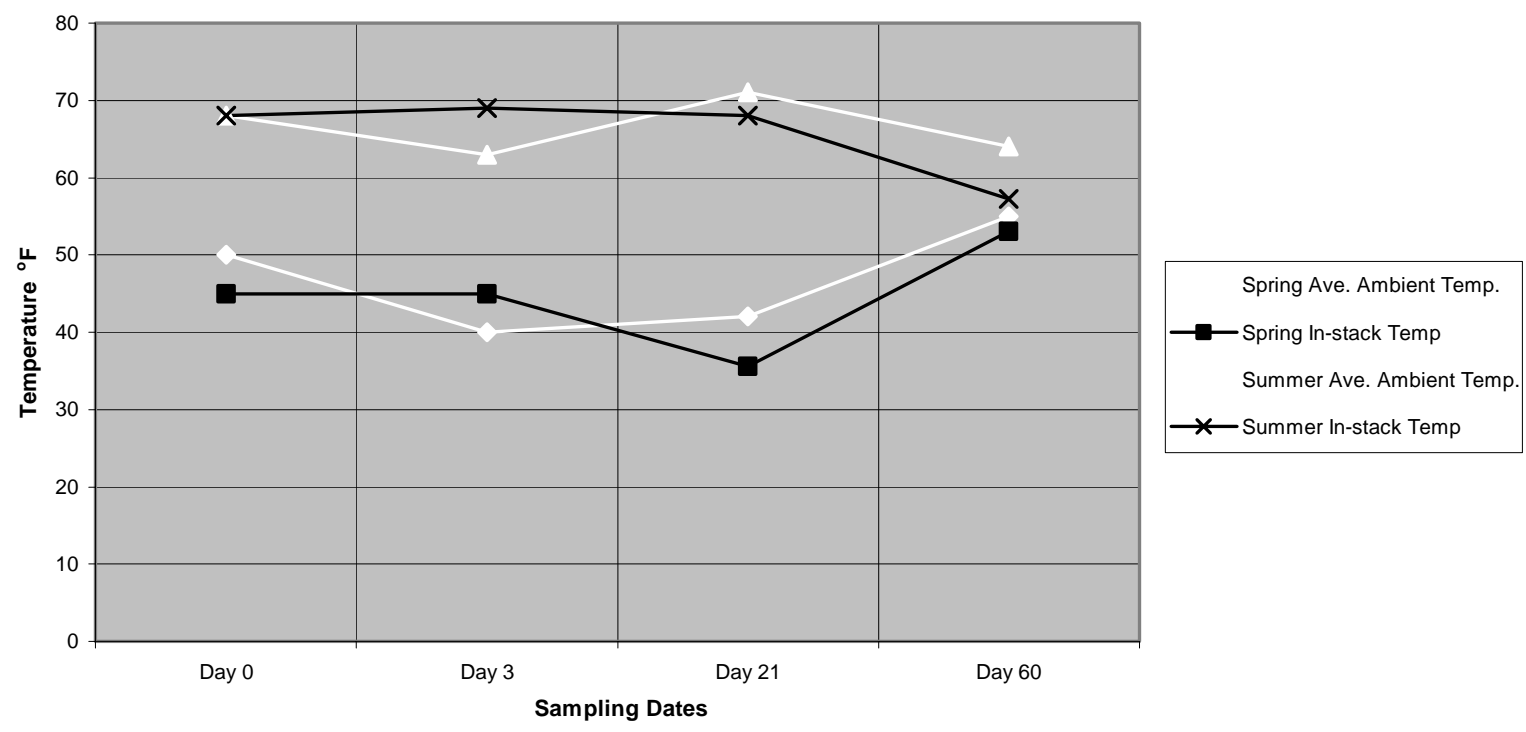


FIGURE 3. Percent of microorganisms colonizing yellow-poplar lumber at various sampling periods in spring and summer of 2000.
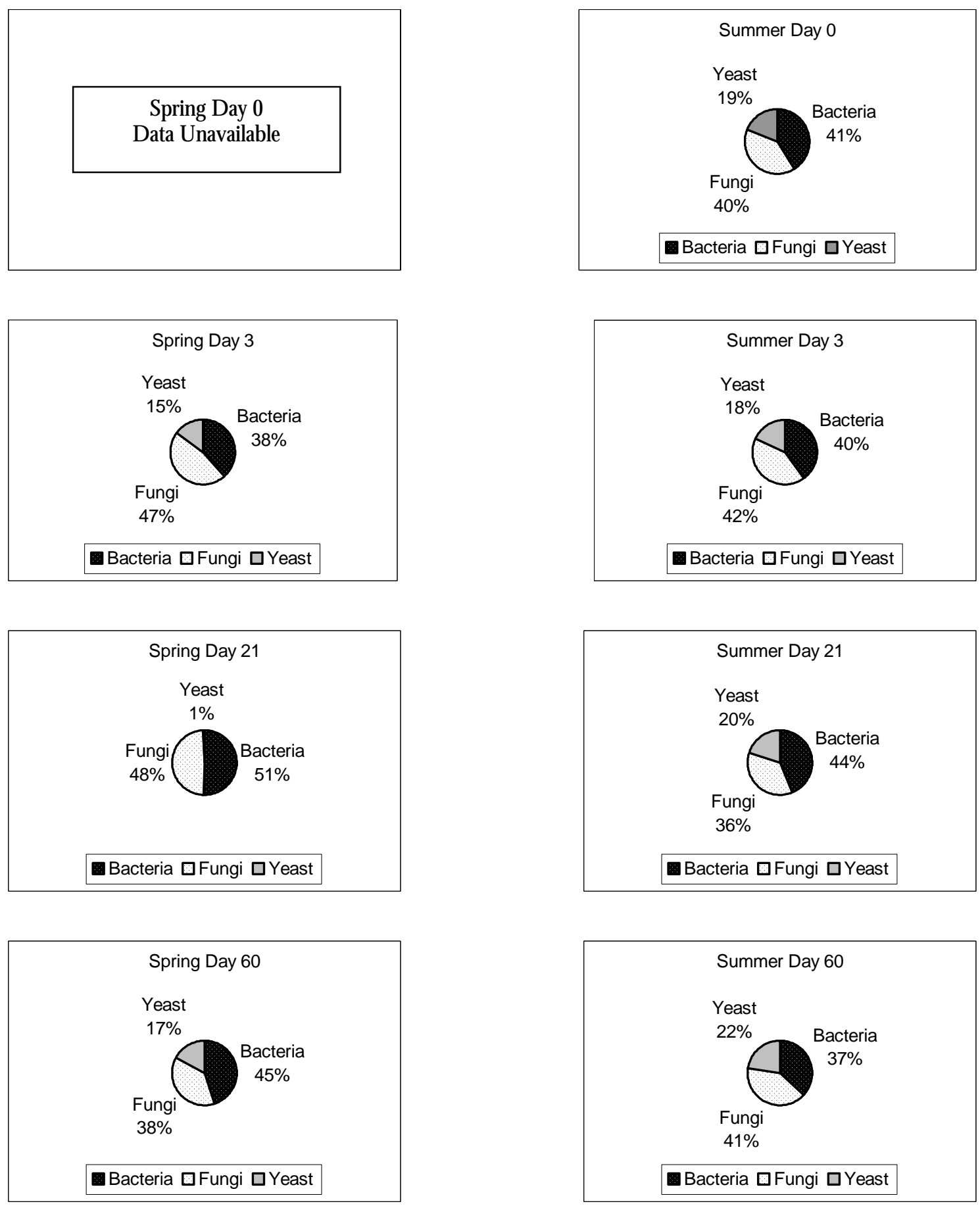
FIGURE 4. Comparison of bacterial abundance and ambient average temperature between sampling periods for spring and summer 2000.

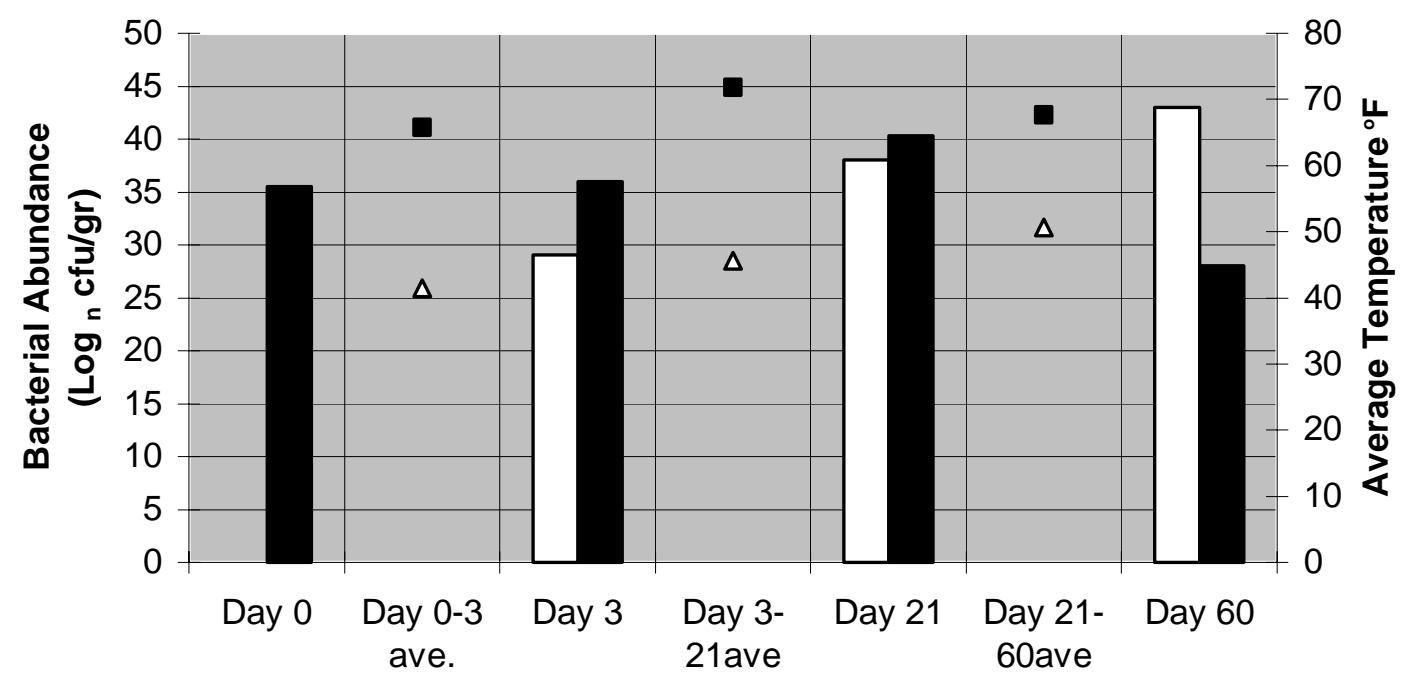

Sampling Periods

$\square$ Spring $\square$ Summer $\square$ Spring - - Summer

FIGURE 5. Percent $(\%)$ of total bacteria positively identified (SI $>0.5$, Separation $>0.1$ ) from freshly sawn yellow poplar lumber.

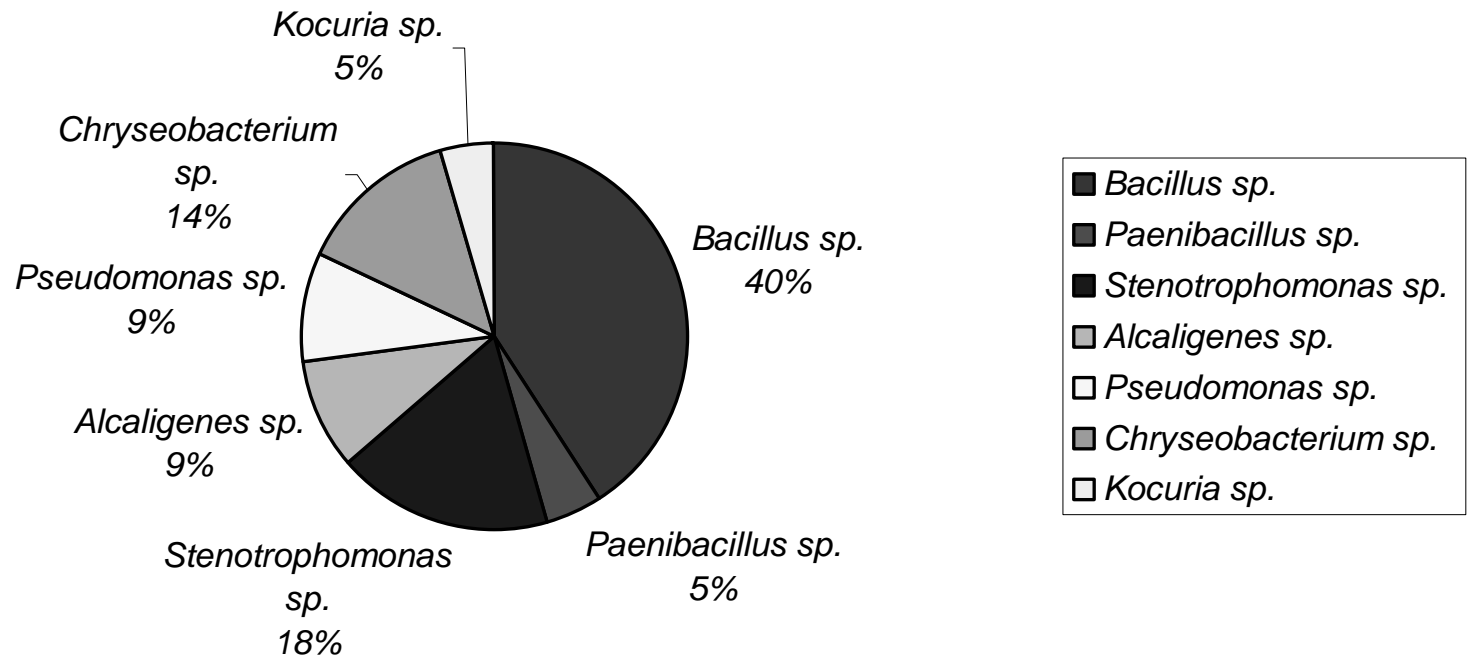


TABLE 1. Bacterial abundance per sampling period during spring and summer of 2000.

Bacterial Abundance

\begin{tabular}{lcccc} 
& \multicolumn{3}{c}{ Spring } & \multicolumn{2}{c}{ Summer } \\
\cline { 2 - 5 } $\begin{array}{c}n y y y \\
\text { Dampling }\end{array}$ & $\begin{array}{c}\text { Log } \\
\text { CFU/gram }\end{array}$ & CFU/gram & $\begin{array}{c}\text { Log }_{\mathrm{n}} \\
\text { CFU/gram }\end{array}$ & CFU/gram \\
\hline Day 0 Total & $\mathrm{m}$ & $\mathrm{m}$ & 35.6 & $5.7 \mathrm{E}+05$ \\
Day 0 Average & $\mathrm{m}$ & $\mathrm{m}$ & 11.9 & $1.9 \mathrm{E}+05$ \\
\hline Day 3 Total & 29.1 & $1.7 \mathrm{E}+06$ & 36.0 & $2.3 \mathrm{E}+06$ \\
Day 3 Average & 9.7 & $5.7 \mathrm{E}+05$ & 12.0 & $7.5 \mathrm{E}+05$ \\
\hline Day 21 Total & 38.0 & $3.0 \mathrm{E}+06$ & 40.3 & $5.2 \mathrm{E}+06$ \\
Day 21Average & 12.7 & $9.9 \mathrm{E}+05$ & 13.4 & $1.7 \mathrm{E}+06$ \\
\hline Day 60 Total & 43.0 & $1.1 \mathrm{E}+07$ & 28.1 & $4.8 \mathrm{E}+04$ \\
Day 60Average & 14.3 & $3.7 \mathrm{E}+06$ & 9.4 & $1.6 \mathrm{E}+04$ \\
\hline Total & 110.1 & $1.6 \mathrm{E}+07$ & 139.9 & $8.0 \mathrm{E}+06$ \\
Average & 36.7 & $5.2 \mathrm{E}+06$ & 35.0 & $2.0 \mathrm{E}+06$ \\
\hline m & & & &
\end{tabular}

${ }^{\mathrm{m}}$ Bacterial abundance could not be calculated due to missing sample weight. 
TABLE 2. Characteristics of positively identified bacteria isolated from freshly sawn yellow-poplar lumber in spring and summer of 2000.

\begin{tabular}{|c|c|c|c|}
\hline Bacteria & Gram+ & Gram- & Respiration \\
\hline Bacillus cereus & $\boldsymbol{X}$ & & $\begin{array}{c}\text { Aerobic } \\
\text { (Anaerobic } *)\end{array}$ \\
\hline Bacillus mycoides $^{T}$ & $\bar{X}$ & & Aerobic \\
\hline Bacillus globisporus $^{2}$ & $X$ & & Aerobic \\
\hline Bacillus pumilis & $X$ & & Aerobic \\
\hline Bacillus subtilis & $X$ & & Aerobic \\
\hline Paenibacillus macerans ${ }^{3}$ & $\bar{X}$ & & Aerobic \\
\hline Paenibacillus pabuli & $\boldsymbol{X}$ & & Aerobic \\
\hline Kocuria kristinae $^{4}$ & $X$ & & Aerobic \\
\hline Stenotrophomonas maltophilia ${ }^{5}$ & & $\boldsymbol{X}$ & $\begin{array}{c}\text { Obligately } \\
\text { Aerobic }\end{array}$ \\
\hline Alcaligenes xylosoxydans & & $\boldsymbol{X}$ & $\begin{array}{l}\text { Strictly } \\
\text { Aerobic }\end{array}$ \\
\hline Pseudomonas aeruginosa & & $\boldsymbol{X}$ & $\begin{array}{c}\text { Obligately } \\
\text { Aerobic }\end{array}$ \\
\hline Pseudomonas putida & & $\boldsymbol{X}$ & Aerobic \\
\hline Rahnella aquatilis $^{6}$ & & $\bar{X}$ & Aerobic \\
\hline$\overline{\text { Chryseobacterium meningosepticum }} 7$ & & $X$ & Aerobic \\
\hline
\end{tabular}

Information regarding changes in taxonomic organization and nomenclature were obtained via DSMZDeutsche Sammlung von Mikroorganismen und Zellkulturen GmbH, Braunschweig, Germany. (Last updated: 03/2001) (Referenced on next page). 
${ }^{\text {I} B a c i l l u s ~ m y c o i d e s ~-~ B a c i l l u s ~ c e r e u s ~ v a r . ~ m y c o i d e s ~}$

(Buchanan, R.E., Gibbons, N.E. (eds): Bergey's manual of determinative bacteriology, $8^{\text {th }}$ ed. The Williams \& Wilkins Co., Baltimore 1974.)

${ }^{2}$ Bacillus globisporus - or closely related species (Similarity Index, 0.438; Separation $<0.1$ )

${ }^{3}$ Paenibacillus macerans - Bacillus macerans (Reclassified)

Authors: Schardinger 1905

References: Int. J. Syst. Bacteriol. 30:257 (AL);

[Buchanan, R.E., Gibbons, N.E. (eds): Bergey's manual of determinative bacteriology, $8^{\text {th }}$ ed. The Williams \& Wilkins Co., Baltimore 1974.]

${ }^{4}$ Kocuria kristinae - Micrococcus kristinae (basonym)

Authors: Kloos et al. 1974; Stackebrandt et al. 1995

References: Int. J. Syst. Bacteriol. 45:690;

[Kloos, W.E., Tornabene, T.G., Schleifer, K.H.: Isolation and characterization of micrococci from human skin, including two new species: Micrococcus lylae and Micrococcus kristinae],

[Stackebrandt, E., Koch, C., Gvozdiak, O., Schumann, P.: Taxonomic dissection of the genus Micrococcus: Kocuria gen. nov., Nesterenkonia gen. nov., Kryptococcus gen nov., Dermacoccus gen. nov. and Micrococcus Cohn 1872 gen. emend. Int. J. Syst. Bacteriol. 45: 682-692 (1995)]

${ }^{5}$ Stenotrophomonas maltophilia - Pseudomonas maltophilia (basonym), Xanthomonas maltophilia (basonym)

Authors: Hugh 1981; Palleroni and Bradbury 1993

References: Int. J. Syst. Bacteriol. 43:608

[Swing, J., DeVos, P., van den Mooter, M., De Ley, J.: Transfer of Pseudomonas maltophilia (Hugh 1981) to the genus Xanthomonas as Xanthomonas maltophilia (Hugh 1981) comb. nov. Int. J. Syst. Bacteriol. 33:409-413 (1983)]

[Palleroni, N.J., Bradbury, J.F.: Stenotrophomonas, a new bacterial genus for Xanthomonas maltophilia (Hugh 1980) Swings et al. 1983. Int. J. Syst. Bacteriol. 43:606-609 (1993).]

${ }^{6}$ Rahnella aquatilis - or closely related species (Separation $<0.1$ )

${ }^{7}$ Chryseobacterium meningosepticum - Flavobacterium meningosepticum (basonym)

Authors: King 1959; Vandamme et al. 1994

References: Int. J. Syst. Bacteriol. 44:830

[Vandamme, P., Bernardet, J.F., Segers, P., Kersters, K., Holmes, B.: New perspectives in the classification of the flavobacteria: description of Chryseobacterium gen. nov. Bergeyella gen. nov., and Empedobacter nom. rev. Int. J. Syst. Bacteriol. 44:827-831 (1994)] 


\title{
Chapter 5
}

\section{Microbial ecology of freshly sawn yellow-poplar (Liriodendron tulipifera L.) lumber in} two seasons: Part III. Yeast.

\author{
Mark R. Mikluscak \\ Graduate Student \\ and \\ Benjamin E. Dawson-Andoh \\ Associate Professor \\ Division of Forestry \\ West Virginia University \\ Morgantown, WV. 26506-6125
}

\begin{abstract}
The microbial ecology of freshly sawn yellow-poplar lumber was investigated during spring and summer of 2000 in West Virginia. This paper reports on yeasts identified during the first 60 days of storage after sawing in each season. Yeasts constituted $16 \%$ of the total abundance ( $\log _{n}$ CFU/gram) of microorganisms isolated during the entire study. Trichosporon cutaneum was the predominant yeast and accounted for $42 \%$ of the total yeasts identified. The genus Candida exhibited the greatest variety of isolated yeast species and included C. steatolytica, C. sphaerica, C. humicola, C. incommunis, C. montana and C. kefyr.
\end{abstract}

\section{INTRODUCTION}

Freshly sawn lumber provides a nutrient rich media for the colonization and growth of numerous microorganisms including fungi, bacteria, and yeast (Rossell et al. 1973; Levy 
1975; Sorenson et al. 1991). Fungi colonizing freshly sawn lumber may cause it's discoloration and subsequent loss of value on the lumber market. Fungal discoloration of wood is effectively controlled by the use of biocides (anti-sapstain chemicals). However, due to the increasing general public concern about safety to workers and potential negative environmental impact, alternative methods of control are being pursued. Biological control is one such alternative. Although bacteria and fungi have been studied as potential biological control agents for inhibiting the growth of decay and sapstain fungi, few reports exist of yeast tested in a similar nature (Payne et al. 2000).

Yeasts have been reported as common colonizers of wood (Shehata et al. 1955; Sorenson et al. 1991). Although Sorenson and his colleagues' study represents one of the most complete reports of yeast isolated from wood, few studies have focused on the activity of yeasts in relation to other microflora colonizing wood, in particular freshly sawn hardwood lumber. Only a limited amount of information about the role of yeasts in wood microbiology is available (Sorenson et al. 1991).

Shigo and Hills (1973) reported that yeasts are intimately associated with pioneer fungi. Yeasts exert a specific force against the substrate they are colonizing as well as other inhabitants of that niche (Shigo and Hills 1973). Interaction between yeasts and other microflora colonizing the same substrate can occur in a variety of ways. Microbial interaction may be antagonistic, synergistic, or mutualistic (Rossell et al. 1973). Results of several studies have demonstrated the antagonistic relationship that can exist between yeasts and other microorganisms. A case in point is the inhibition of the growth of green and blue mold by the yeast Debaryomyces hansenii (Chalutz 1990). Payne et al. (2000) established that yeasts can reduce the growth of certain wood decay Basidiomycetes, molds, and stain fungi, however, only under laboratory conditions. Conversely, Shigo (1965) reported that certain yeasts actually enhance the production of pigments by fungi and stimulate growth, thus, demonstrating a synergistic relationship. 
During their growth, yeasts may impact both the chemical composition and colonization patterns of microflora on a particular substrate. This occurs through nutrient utilization and production of secondary metabolites. Production of secondary metabolites, such as pigments and volatile organic compounds, by yeasts has been reported in literature (Shigo 1965; Payne et al. 2000; Walker and McLeod 1995). Yeasts with the ability to produce such secondary metabolites have the potential to function as biocontrol agents as indicated by Walker and McLeod (1995). These investigators measured the ability of yeasts to inhibit the growth of wood decay and stain fungi under laboratory conditions and concluded that inhibition was due to the production of a proteinaceous "killer" toxin. The agricultural industry has successfully used yeasts as a biological control agent (Chalutz 1990; Wisniewski et al. 1991; Mercier and Wilson 1994; Filonow et al. 1996). One of the most successful applications of yeasts as biological control agents has been reported in the control of post-harvest diseases of fruits, vegetables, and flowers (Janisiewicz 1988, 1994, 1996; Janisiewicz et al. 1992; Janisiewicz and Bors 1995; Lindow 1991, 1994; Wilson and Lindow 1994).

The use of microorganisms, such as yeasts, as biological control agents is a practical alternative to chemical preservatives because of their harmlessness to humans and the environment, ease of maintenance, non-demanding environmental and nutritional requirements, and is accompanied by their wide distribution in nature (Payne et al. 2000). However, before yeasts can be successfully applied as biological control agents on wood, studies must be performed, which identify not only possible biological control agents for future screening, but also the entire community of microorganisms colonizing the target substrate. Preventive strategies that concentrate on only one microorganism may experience limited success because of the interference from unidentified members of competing microflora (Kang and Morrell 2000). For example, not only are the organic compounds produced by yeasts of particular interest in the formulation of biologically based preservative, but these same compounds must be overcome when introducing biocontrol agents into a system where such microorganisms colonize. Biological control organisms are living organisms whose propagules must germinate or grow to enable and 
exert its effect. Thus, for biological control agents to be efficacious when applied, they must ecologically fit or competent for their target niche (Janisiewicz 1998).

The overall objective of this study was to advance the knowledge that is necessary for successful development of a biological control method to inhibit the growth of microorganisms that cause the discoloration of green lumber by initially studying the ecology of the colonizing microflora. This paper reports on the identity, occurrence, species richness, and species diversity of yeasts associated with the microflora colonizing green yellow-poplar lumber. The results of this study should provide direction for future evaluation of yeasts as potential biological control agents.

MATERIALS AND METHODS

\section{Climate/ Environmental Factors}

Climatological data monitored during this study included average ambient temperature, relative humidity, and precipitation. This data was obtained from the National Climatic Data Center (NCDC). The NCDC local climatological data was recorded at the Hart Field Airport in Morgantown, WV (Elevation 1248 feet). Hart Field is located approximately eight miles east of WVU Research Forest (2600 feet), the study site. In an attempt to characterize the atmospheric conditions in the period leading up to sampling (instead of simply the actual sampling date), an average was calculated for each of the environmental factors. Thus, the climatological data was averaged between each of the consecutive sampling periods (between Days 0 and 3, Days 3 and 21, and Days 21 and 60).

\section{Lumber}

\section{Lumber stack}

Yellow-poplar trees (20" diameter at breast height), randomly selected from the West Virginia University (WVU) Forest, were felled and bucked into logs one week prior to setup of this study. The WVU Research Forest is located near the main campus of West Virginia University in Morgantown, WV. This study focused on two seasons, spring $(03 / 01 / 00$ to $04 / 30 / 00)$ and summer $(07 / 15 / 00$ to $09 / 19 / 00)$, and fresh material was 
produced prior to each season. Logs were sawn into nominal $8 / 4 \mathrm{X}$ variable width $(>6$ inch) boards. Freshly sawn yellow-poplar boards were taken directly from the green chain and immediately arranged in a dead-stack (without drying stickers). The stack measured approximately 2.5 feet wide by 1.6 feet high and was composed of 45 boards arranged in five columns and nine rows. The entire lumber pile was placed on two billets (4 inches x 4 inches) that were resting on cinder blocks. This arrangement allowed for a clearance of approximately 1.5-2.0 feet above the ground. A plastic sheet, which was weighed down, covered the top of the stack to prevent contact of direct rainfall. During summer, a plastic sheet was placed underneath the stack to reduce the anticipated increase in vegetative growth from contacting the stack. A detailed description of the lumber stack and the sampling zone is reviewed in part one (Chapter 3) of this study. During both seasons, select boards (from the sampling zone) were sampled on Days $0,3,21$, and 60 after sawing. The same boards were sampled throughout each season. On each date, the stack was disassembled to enable sampling and then each board was placed in its original location within the stack.

\section{Lumber appearance}

On each of the sampling dates, visual observations of the stack and of each board were recorded.

\section{Sampling of lumber boards}

As described in part one (Chapter 3) of this study, three boards in the sampling zone of the lumber stack were sampled. The same individual boards, which were randomly selected prior to each season, were sampled on each of the sampling dates described earlier. Wood samples were tested for moisture content, $\mathrm{pH}$, in-stack temperature, and yeast. Detailed descriptions of the sampling protocol employed during this study are given in part one (Chapter 3).

\section{Moisture Content}

Three wood samples taken from the same area of each board with an increment borer 
(Figure 1) were combined, placed in sterile plastic bags, and sealed. The area of the boards that were sampled is reviewed in more detail in part one (Chapter 3) of this study.

$p H$

The same procedure described above for moisture content was used to extract wood samples tested for $\mathrm{pH}$. Wood samples were taken with an increment borer and placed in pre-sterilized plastic bags.

\section{In-stack Temperature}

On the initial set-up date of the lumber pile in each season (Day 0), a temperature probe was placed between rows four and five of boards in the stack. The probe remained in this position for the length of the study. The in-stack temperature was recorded only on each sampling date described earlier.

\section{Yeast}

As described earlier, each board sampled for moisture content and $\mathrm{pH}$ also was analyzed for colonizing yeasts. Wood samples were taken from the center 12-inch section of selected boards with a modified $1 / 2$ inch boring bit set to a depth of $1 / 4$ inch. This boring bit was built based on the principles of a similar device designed by Dutkiewicz et al. (1992) to quantify microorganism on wood. The boring bit was pre-sterilized by dipping in $90 \%$ ethanol and flaming it prior to sampling. Three samples were taken from the same area of each board, combined, and placed in sterile sealable plastic bags. Each board was sterilized by swabbing the sampling area with $90 \%$ (volume/volume, v/v) ethanol and flaming it. This sterilization method was employed to preclude isolation of surface microorganisms and their propagules. After sampling was complete on each date, the lumber stack was repiled with each board being placed in its original location within the stack. The same boards were sampled throughout the length of the study to reduce the variability between boards. 


\section{SAMPLE ANALYSIS}

\section{Lu mber}

\section{Moisture Content}

The average moisture content (dry-basis) of each board was determined by oven-drying as per ASTM D 4442-92 Standard (2001).

\section{$p H$}

Wood samples were measured for $\mathrm{pH}$ as per a modified US Forest Products Laboratory procedure (Moore and Johnson 1997). The US Forest Products Laboratory procedure for wood $\mathrm{pH}$ determination is reviewed in part one of this study. The $\mathrm{pH}$ was measured with a Corning $\mathrm{pH} /$ ion analyzer 350 and a Corning flat-surface combination electrode at $25^{\circ} \mathrm{C}$.

\section{Yeasts}

Yeasts were isolated as per Dutkiewicz et al. protocol (1992). Wood shavings produced by the boring bit were weighed and placed in $45 \mathrm{ml}$ sealable vials that contained $20 \mathrm{ml}$ of sterile phosphate-buffered saline solution with $0.1 \%(\mathrm{v} / \mathrm{v})$ Tween 80 . Each vial and its content were shaken on a rotary shaker for one hour at $100 \mathrm{rpm}$. Ten-fold serial dilutions $\left(10^{0}\right.$ to $10^{-5}$ ) were made (Pepper et al. 1995). One-tenth milliliter $(0.1 \mathrm{ml})$ aliquots of each dilution were spread on duplicate sets of yeast malt agar plates (Difco, Inc. 2000) containing tetracycline (Dutkiewicz et al. 1992). Inoculated petri-plates were incubated at $28{ }^{\circ} \mathrm{C}$ for a minimum of 96 hours (Dutkiewicz et al. 1992).

At the end of incubation period, colonies were counted and isolated into pure cultures. All yeast colonies were segregated based on growth behavior on agar, microscopic cellular characteristics and colony morphology and placed into separate groups (Dutkiewicz et al. 1992; Schmidt 1985). The abundance of yeasts was reported initially in terms of colony forming units (CFU) per unit gram of wood and was the mean of all the plates in which $\mathrm{CFU} /$ gram could be counted. Yeast abundance was transformed using the natural log (Log n). Since the data was only transformed and remained in the same order as the original observations, any conclusion about the transformed data is true for the original (Dowdy and 
Wearden 1991). The main disadvantage to the transformation of data in this manner is that the results are reported in unusual units (Dowdy and Wearden 1991). For example, the abundance of yeast is reported as the $\log _{n}$ (natural $\log$ ) of the number of yeast per gram of wood (Dowdy and Wearden 1991).

\section{Microbial Identification}

Yeast isolates obtained from wood samples were identified by Robert Brooks at WoodsonTenent Laboratories, Division of Eurofins Scientific, Inc. (ID 32C yeast identification system) and by Dr. Ellen Dickstein at the University of Florida, Plant Pathology Department (BIOLOG YT Microplate System).

The ID $32 \mathrm{C}$ is a system for the identification of yeasts using assimilation tests with a specifically adapted database. This system incorporates the use of an ID 32C strip, which consists of 32 capules containing dehydrated carbohydrate substances. A defined media was inoculated with a suspension of each yeast that was tested, incubated for 24-48 hours, and analyzed for growth both visually and by ATB instruments. Identification was obtained by reference to the Analytical Profile Index.

The Biolog YT Microplate system tests the ability of yeasts to utilize or oxidize a preselected panel of carbon sources. All nutrients and biochemicals were prefilled and dried into 96 wells of the plate. Yeast isolates were suspended in pre-warmed sterile water within the density range specified. The cell suspension was inoculated into the Microplate, $100 \mu \mathrm{l}$ per well. All initial wells were colorless. When substrates in the well were utilized, an increase in turbidity was produced due to either growth or an increase in respiration due to the tetrazolium dye and a purple color was formed. The Microplates were incubated for 24, 48, and 72 hours. The resultant metabolic patterns of samples were interpreted by Biolog's MicroLog3 computer program and cross-referenced with the pattern of a library of yeast (Biolog, Inc. 2000). When interpreting results produced by the BIOLOG YT Microplate system, the Similarity Index (SI) must be at least 0.75 at 24 hours and 0.50 at 48 or 72 hours to be considered acceptable. 


\section{Characterization of microbial community}

Biological communities can be characterized by species diversity (Krebs 1999). Species diversity can be expressed by several indices. These indices are a measure of the importance of a species in a community in terms of numbers, biomass, and cover of productivity (Krebbs 1999). For all diversity indices, the common underlying assumption is that "all species are equally different (Krebs 1999)." Two indices, Species Evenness (SE) and Species Richness (SR) were used in this study.

Species Evenness was measured in total for both seasons included in this study by using the Berger-Parker Dominance Index (BPDI) (Chapter three, Brown 1985). Species Richness $(\mathrm{SR})$, which is a measure of the number of species present in a sample, was used to estimate the number of species identified on each sampling date and as a general comparison of the species isolated in both seasons (Chapter three, Brown 1985).

\section{RESULTS}

\section{Climate / Environmental Factors}

Environmental factors monitored in this study included ambient temperature, relative humidity, and precipitation. A detailed review of these factors can be found in part one (Chapter 3) of this study.

\section{Temperature}

The average ambient temperatures recorded during this study, ranged from 33 to $67^{\circ} \mathrm{F}$ and from 51 to $80^{\circ} \mathrm{F}$ in spring and summer, respectively. The highest average ambient temperatures were observed between Days 21 and 60 during the spring and between Days 3 and 21 during the summer.

\section{Relative humidity}

Relative humidity at Hart Field Airport ranged from 33.3-95.9\% and 60.6-97.0\% per day in spring and summer, respectively. 


\section{Precipitation}

Average precipitation recorded at Hart Field Airport ranged from 0.05 to 0.14 inches per day during spring and from 0.06 to 0.16 inches per day during summer.

\section{Lumber}

\section{Lumber appearance}

No lumber discoloration was observed during the first two sampling periods (Days 0 and 3) in either season (spring or summer) of this study. The first signs of discoloration were not noticed until sampling on Day 21 of both seasons. On Day 21 in spring and summer, a blackish discoloration and a pink-red stain was observed on boards. Unidentified insects also were noticed on the surface of boards within the lumber stack on this date in both seasons. Lumber discoloration appeared more severe in the final sampling period (Day 60) in both seasons of this study. The bright pink-red colored stain had developed into a darker red color between Days 21 and 60 and was observed only on boards in the top portion of the lumber stack.

\section{Moisture content}

In general, moisture contents of dead-stacked lumber ranged from $35 \%$ to $62 \%$ in spring and from $59 \%$ to $70 \%$ in summer. Lumber boards retained a high moisture content as the study progressed to 60 days of storage in each season. The average moisture content of boards sampled in spring decreased from the processing date (Day 0) to Day 3 and increased markedly for the remainder of the study. The average moisture content observed during summer decreased from Day $0(70 \%)$ to Day $21(59 \%)$, followed by an increase on Day $60(66 \%)$.

\section{$p H$}

Average $\mathrm{pH}$ of yellow-poplar lumber in a dead-stack during this study became increasingly more alkaline with increasing time of storage up to Day 21 in both spring (4.6-4.9) and summer (4.6-4.7). In spring, a lag was observed on Day 60 (4.6), however, in summer the 
average $\mathrm{pH}$ continued to increase (4.8).

\section{In-stack temperature}

Temperature within the lumber stack was generally lower than the ambient temperature, and experienced less variation per sampling date. The in-stack temperature ranged from 35.6 to $53.0^{\circ} \mathrm{F}$ in the spring and from 57.2 to $69.0^{\circ} \mathrm{F}$ in summer.

\section{Yeast}

Total yeast counts obtained from wood samples in spring and summer were 28.4 and 68.1 ( $\log _{n} \mathrm{CFU} /$ gram), respectively. These values exclude the abundance of yeast on Day 0 in spring due to missing sample weight. Per sampling period, total yeast counts for spring and summer ranged from 0.7 to 16.4 and 16.3 to 18.4 ( $\log _{n}$ CFU/gram), respectively. The greatest abundance of yeasts was observed on Day 60 in spring and Day 21 in summer (Figure 2). However, yeasts accounted for its highest percent of the total microbial abundance per day on Day 60 of summer. On this sample date, yeast isolates represented $22 \%$ of total microbial abundance. Spring sampling represented a pattern of decreasing yeasts abundance from Day 3 to Day 21, followed by a vast increase on the final sampling period (Figure 2). The average abundance of yeasts isolated during summer followed a consistent pattern and minimal variation was experienced on each individual sampling date. A slight increase was observed on Day 21 (18.4 $\log _{n}$ CFU/gram) and a slight decrease on Day 60 (17.0 $\log _{\mathrm{n}} \mathrm{CFU} /$ gram) in respect to yeasts abundance (Figure 2 and Table 1 ). A type III test of the Least Square Means (LSM) using the GLM Procedure (SAS) showed no significant difference $(\mathrm{P}>0.05)$ between the abundance of yeasts ( $\left.\log _{n} \mathrm{CFU} / \mathrm{gram}\right)$ per season, sampling date, or per sample board.

In total, yeasts constituted $16 \%$ of the total population of microorganisms isolated in this study (Figure 3). Four genera and nine species of yeasts were positively identified (Table 2). Trichosporon cutaneum was the predominant yeast and accounted for $42 \%$ of those identified (Figure 4). The genus Candida had the greatest number of species identified. The period of isolation of all yeasts identified during this study is listed in Table 2. 
Although the abundance of yeast was not computed due to missing data (sample weight) for Day 0 of spring, yeasts identified included T. cutaneum and 4 different species of Candida. During summer sampling (Day 0), T. cutaneum, and C. humicola were identified.

On Day 3 of the spring, a single species, Rhodotorula rubra was isolated. In summer, however, T. cutaneum, and Pichia amenthionina were identified.

Sampling on Day 21 of spring produced the lowest overall abundance of yeasts $(0.7 \log \mathrm{n}$ CFU/gram) and only the yeast, $T$. cutaneum, was identified. Conversely, Day 21 of summer represented the highest total abundance of yeasts for the entire study (18.4 $\log \mathrm{n}$ CFU/gram). Identified isolated yeasts included $C$. incommunis and P. amenthionina.

In spring, $C$. steatolytica, and T. cutaneum, were identified on Day 60. However, only $C$. incommunis was identified in summer on Day 60.

Overall, thirty-two representative yeasts were isolated, established in pure cultures, and analyzed for identification. From this total, six isolates contained profiles that did not be matched to the databases used or meet the prescribed specifications( ID 32C yeast identification system).

\section{Species Richness and Evenness}

The Species Richness (SR) values for spring and summer, in total, were thirteen and eleven, respectively. Per sampling period, the highest measure for SR (eight) was encountered on the initial sampling date (Day 0) of spring. This number indicates that eight species of yeast were identified from isolates obtained on this sampling date. 
The Berger-Parker Dominance Index (BPDI) values calculated in spring and summer on average were 0.6 and 0.4 , respectively. These data represent the proportion of individuals that were of the most abundant species in the samples collected.

\section{DISCUSSION}

\section{Lumber appearance}

To date, no studies have reported on the staining of wood by yeasts. Fungi is assumed to be the primary cause of the dark discoloration observed during this study. However, some yeasts produce colored colonies and pigments during growth. A case in point is the formation of pink colonies Rhodosporidium sp, Sporobolomyces sp, Cryptococcus sp, and Phaffia sp (Barnett et al. 2000; Stokes 1971). The genus Rhodotorula is composed of mainly red yeasts with the ability to produce red carotenoid pigments (Barnett et al. 2000). In this study Rh. rubra, one such yeast with this ability (Barnett et al. 2000), was identified but isolation occurred previous to the appearance of this pink-red discoloration on Day 3 of spring and no correlation could be made.

Lumber stacks in both spring and summer were observed to have a pinkish-red discoloration of boards on Days 21 and 60. Is it a coincidence that the stain occurred during the same periods in both seasons? Does this observation indicate that seasonal temperatures may not influence the production of pigments by microorganisms? Simpson et al. (1971) reported that most yeasts do not change their pigment ratio with temperature change and factors other than temperature may be the primary influencing force for the appearance of such pigmentation and the yeasts that produce them. For example, the majority of the observed pink-red stain occurred on boards located on top of the lumber stack. Light is often associated with the development of pigments (Simpson et al 1972). Light stimulation of carotenoid pigments in yeasts, notably Rh. Rubra, has been reported by Lederer (1933). This relationship between pigment production and light may account for or explain the occurrence of this pinkish-red stain only on lumber boards located in the top layer of lumber stack where light was most prominent or available. Since the pink-red discoloration was encountered on boards outside the sampling zone, no correlation could be 
associated between the growth of yeast and discoloration. Further, no tests were performed in this study to determine if those yeasts isolated produced such pigments.

\section{Effect of Environmental and Physical Factors}

Distribution and interaction between resident microflora is mediated by several biotic and abiotic factors including $\mathrm{pH}$, moisture content, temperature, antibiotic production, and nutrient competition. In this study, several environmental and physical factors were monitored to determine their relationship to the abundance of yeasts and also gain a general understanding of the environment from which these yeasts were isolated.

\section{Temperature}

Temperature influences the development of interaction between microorganisms (Henningsson 1967). It may also be in the development, metabolism, sporulation, growth, and survival of yeasts in particular (Stokes 1971; do Carmo-Sousa 1969). The ambient conditions recorded during this study were typical for the area. No apparent trend was discerned between the abundance of yeasts and the average ambient temperature in this study. Minimal variation was encountered in the abundance of yeast isolated during the sampling periods in both seasons. No significant difference $(\mathrm{P}>0.05)$ was found in the abundance of yeast isolated from individual boards between seasons or sampling dates. These results confirm the findings of Sorenson et al (1991) who reported that no significant difference $(\mathrm{P}>0.05)$ was encountered between yeast samples taken from stored timber from May to August. Further, studies involving the isolation of yeasts from leaves have reported that the greatest abundance of yeasts occurs in late spring and summer, and decreases with autumn rainfall and winter (Last and Price 1969). Since the present study included sampling only during the spring and summer seasons, no such correlation could be made.

\section{In-stack temperature}

The in-stack temperature varied less than that of the ambient air during the periods of this study. This observation could be attributed to the insulative properties of wood and the close proximity of the boards in a dead stack configuration (Chapter 3). Significant 
differences were observed between the in-stack temperatures recorded in both seasons, but no relationship could be discerned between the in-stack temperature and the abundance of yeasts.

\section{Moisture content}

The moisture content of lumber boards remained relatively high throughout the periods of this study. This is characteristic of dead stacked-lumber. The observed increase in moisture content of the boards could be ascribed to the increase in precipitation and relative humidity in the periods leading up to sampling. Although microbial growth is influenced directly by moisture content, other factors such as temperature, substrate composition, and time greatly affects growth (Pasenen et al. 1992). There was no correlation between board moisture content and the abundance of yeast.

$p H$

Wood is a heterogeneous material and thus the $\mathrm{pH}$ value of wood samples is variable depending on the location from which samples are taken. The $\mathrm{pH}$ of wood is affected by several factors including moisture content and precipitation (Gray 1958; Highley and Lutz 1970). No relationship was observed, however, between the moisture content and $\mathrm{pH}$ of wood samples in this study. Nor was any correlation observed between the $\mathrm{pH}$ of wood samples and the precipitation recorded during this study.

Growth of microorganism also may influence the $\mathrm{pH}$ of wood. Substrate $\mathrm{pH}$ may be altered by microbial activity (Asante and Neal 1964; Highley and Lutz 1970). Certain species of yeast, for example, can alter the $\mathrm{pH}$ of a substrate through the production of organic aids during growth (do Carmo-Sousa 1969). Yeast, as opposed to other resident microflora, grow very well at a low $\mathrm{pH}$ level. The $\mathrm{pH}$ of yellow-poplar has been reported as $5.43 \pm 0.21$ and 4.50 (Koch 1985; Highley and Lutz 1970), which fairly agrees with the results of this study. The mildly acidic environment of yellow-poplar lumber should be suitable for the optimum growth of yeasts. However, this appears not to be the case in this study since yeasts represented the lowest percent of the total microbial population 
abundance. No factors could be attributed to the change in yeasts abundance and the $\mathrm{pH}$ of boards.

\section{Yeast}

Yeasts are part of the microbial community colonizing various substrates in nature such as soil, twigs, leaves, leaf litter, and humus (Kreger-Van Rij 1969). Several reports (Dutkiewicz et al. 1992, Sorenson et al. 1991, and McCreary et al. 1965) are in agreement with the results of this study, which indicates that yeasts readily colonize wood. However, yeasts comprised only $16 \%$ of the total microbial population which is lower than the level of yeasts obtained from wood previously reported by Sorenson et al. (1991). These authors reported that "yeast were the predominant fungi" and "were often in excess of $90 \%$ of the fungi observed" in samples taken from timber (Sorenson et al. 1991). Critical growth factors such substrate characteristics, storage length, and the colonizing community of microorganisms were different in this and Sorensen et al.'s studies and therefore may be responsible for the observed differences.

\section{Species Richness and Evenness}

One of the most noteworthy observations made during the course of this study was the high SR of yeasts on Day 0 (spring) of the study. This is indicative of a variety of yeast species colonize lumber immediately after sawing. Studies report that yeasts may be airborne in the environment and represent as much as $20 \%$ of the total fungal population in air at ground level with Cryptococcus sp and Rhodotorula sp being the most frequently identified yeast (Kreger-Van Rij 1969). The composition of the air may be an important element to be considered in the colonization of wood. Freshly sawn lumber provides a nutrient rich media which encourages the growth of microorganisms, such as yeasts. However, other factors could be important since this same observation was not observed during Day 0 of summer. These results indicate that the development of BCA should incorporate immediate application after processing to deal with the initial high incidence of yeasts.

BPDI is a measure of the species evenness in a sample and describes the distribution of 
species abundance. The BPDI for spring and summer were 0.6 and 0.4 , respectively. As mentioned earlier, these values represent the proportion of all yeasts that belong to the most abundant species. The BPDI values indicate that seasonal conditions did not have an enormous effect on the evenness of the community. In both spring and summer, nearly half of the yeast isolated belonged to the most abundant species according to this index.

Yeasts isolated from decaying wood include Hansenula sp, Pichia sp, Saccharomyces sp, and Candida sp (do Carmo-Sousa 1969). Other yeasts that have been isolated from wood include Rhodotorula rubra, C. humicola, Sporobolomyces sp, and Trichosporon sp (Sorenson et al. 1991; Shehata et al. 1955; Kreger-Van Rij 1969). The majority of these yeasts were isolated in this study (Table 2).

Trichosporon cutaneum was the most frequently isolated yeast and accounted for $42 \%$ of the total yeasts identified. Kreger-Van Rij (1969) reported that T. cutaneum is one of the most frequently isolated species from decomposing litter, soil, and humus. This study was set up in close proximity to the WVU Forest where twigs, soil, and leaf litter most definitely built up over time around the lumber stack and may, in part, explain the isolation of this species. Another factor that may influence the isolation of this species is the method of storage and handling of freshly sawn logs and lumber. For example, freshly sawn lumber or logs which came in contact with leaf litter or soil during the set up of the deadstack may have increased the incidence of isolation of this species. Trichosporon cutaneum also has a wide range of synonyms, notably 68 , and this also may explain this species accounting for nearly half of those yeasts that were identified in total during this study (Kreger-Van Rij 1969; Barnett et al. 2000).

Another commonly found yeast in nature is Candida sp. The genus Candida was represented by the most number of species in this study (Table 2). Candida sp is one of the most common environmental yeast and has been reported to be the second most dominant yeast associated with stored timber (Sorenson et al. 1991). Candida sp was isolated at a relatively high frequency during this study and accounted for around $40 \%$ in total of those 
yeasts identified.

Some of the yeasts identified as part of the current study may be of particular interest to the characterization of the microflora of freshly sawn wood. For example, C. humicola has been reported to be one of the most dominant yeasts isolated from soil (Kreger-Van Rij 1969). Like T. cutaneum, C. humicola is one of the most frequently isolated yeasts from twigs, leaves, and trees (Kreger-Van Rij 1969). Candida humicola produces starch on substrates with a low $\mathrm{pH}$ and thus, may influence the nutrient composition and consequent colonizers of a substrate such as wood (Kreger-Van Rij 1969). In particular, this may be the case in studies such as this which utilize wood species with a lower $\mathrm{pH}$, like yellowpoplar.

As stated earlier the physical and environmental factors monitored during this study appeared to have no direct relation to the abundance of yeasts. This leads to the assumption that factors other than those included in this report are the main limiting factors for the growth and colonization of yeast on wood. One such factor is the available nutrients. In all aspects of life, available nutrition and the competition for nutrients play intricate roles in survival and growth. This is no different on the microbial level. Due to the large surface area in relation to cell mass, yeast are able to quickly utilize nutrients and should make them well suited for colonization of freshly sawn lumber where simple sugars and nutrients are high (Suomalainen and Oura 1971). The ability to quickly utilize nutrients seemed to be demonstrated by the immediate colonization of yeasts isolated on Day 0 in both seasons of this study.

Colonization of yeasts also may be, in part, dependent on the activity of previously colonizing microorganisms. For example, Last and Price (1969) reported that microorganisms, such as bacteria, make essential nutrients available during their growth. Thus, colonization of certain yeast species may be a result or influenced by the action of other pioneer colonizing microflora. In contrast, some yeasts are nutritionally versatile. Several species of Candida, for example, possess the ability to utilize a wide variety of 
different carbon compounds present in low concentrations (Kreger-Van Rij 1969). This may explain the wide distribution of this yeast in this and other studies (Kreger-Van Rij 1969). In contrast, yeasts such as Pichia sp can utilize only a few carbon sources (KregerVan Rij 1969). Pichia sp was identified only once in this study and nutritional limitations may explain the low frequency of isolation. Nutrient competition has been suggested as one of the defining factors in antagonism in relation to yeast and may be the most important factor in yeast ecology (Wisniewski et al. 1991; do Carmo-Sousa 1969). Although the available nutrients present during this study were not investigated, this is an important factor, which should be considered by those wishing to advance this study.

Although physical factors, environmental conditions, and/ or nutritional requirements are influential to the growth of yeast, microorganisms competing for the colonization of the same substrate must be included in the characterizing the microbial ecology of wood. The affects of primary and secondary colonizers - their ability to produce antibiotics, organic acids, as well as the carrying capacity of a substrate are important factors that must be incorporated into the microbial ecology of freshly sawn lumber.

Production of antibiotics or secondary metabolites on wood has not been clearly demonstrated in the field. However, in a study performed by Payne et al. (2000), yeast isolates with the ability to produce antibiotics reduced the growth of fungi under laboratory conditions. A similar laboratory study indicated that the yeast $P$. guilliermondi and other biocontrol yeasts inhibited the growth of the fungus Auerobasidium pullulans (Mercier and Wilson 1994). Research performed under laboratory conditions has demonstrated, however, that yeast, themselves, also can be inhibited in growth by antibiotics produced by other resident microflora (do Carmo-Sousa 1969; Last and Price 1969).

Although bacteria and filamentous fungi have been documented as primary colonizers of wood, the significant isolation of yeast directly after processing of logs into lumber also must be considered to characterize the infecting community on lumber and in the development of effective BCAs to prevent stain. The composition of the microbial ecology 
of the lumber in this study, characterized by the immediate colonization of yeast, indicates that Biological Control Agents must inhibit the growth of a variety of microflora and that quick application of a preservative after processing is needed. There is a need for further research to determine the interaction of these microorganisms obtained from wood, as well as the influence of physical factors, such as temperature, moisture content, $\mathrm{pH}$, and nutrients. Future research efforts should consider studying the entire microbial community of wood as well as those factors listed above.

This study clearly shows that yeast colonize green yellow-poplar lumber in a dead-stacked lumber package during storage. Past studies indicate that the concentration of yeast is highest during the early phases of wood colonization (Shigo and Hills 1973; Kaarik 1975). This statement is confirmed statistically because no significant differences were detected in yeast abundance isolated from boards at sampling dates or in each season. That yeast abundance remained fairly consistent throughout the first 60 days of storage in each of two seasons. This study shows consistent yeast abundance in each sampling period (with the exception of Day 21 in spring) and no significant difference was determined between season, board, and sampling date.

The results of this study which indicate that yeast colonize lumber immediately after sawing accompanied by the fact that yeasts grow well at a low $\mathrm{pH}$ value does provide some encouragement for their use as biological control agents if the substrate $(\mathrm{pH})$ can be manipulated to increase or promote their growth.

The yeast that colonize hardwood lumber are of special interest because until now a complete study has not existed that characterizes and identifies the complete community that colonizes wood. In respect to those microorganisms that naturally exist or colonize wood, certain species can be screened in future studies in an attempt to inhibit the staining of wood by sapstain fungi. 


\section{CONCLUSION}

The data presented in this study confirms the observations of other researchers who reported on the diversity of microorganisms, in particular yeast, colonizing wood (Sorenson et al 1991; do Carmo-Sousa 1969; Shehata et al. 1955). The yeast identified during the colonization of freshly sawn lumber in this study was dominated by the genera Trichosporon and Candida. This is in agreement of previously performed studies. Other yeasts, such as Rhodotorula sp, and Pichia sp, also were present in this study, but at a lower frequency. The presence of yeast on the initial processing and set-up date indicate that freshly sawn hardwood lumber is susceptible to immediate attack by microorganisms. Development of Biological Control Agents (BCAs) must incorporate the affect of each group of microorganisms and is accompanied by the need for application of the BCAs prior to or immediately following processing. Data also shows that if yeast were applied as BCAs, the colonization of several species is immediate after sawing.

\section{ACKNOWLEDGEMENTS}

The authors thank Dr. Daniel Panaccione and Mr. Mark Double for their multitude of assistance; Dr. William Thayne and Dr. Mark Brown for statistical support; Jeffrey Slahor, George Mikluscak for technical and mechanical assistance; Dr. Ellen Dickstein and Dr. Robert Brooks for the identification of yeast isolates; and Robert Driscole West Virginia University Forest Manager.

\section{REFERENCES}

American Society for Testing AND Materials. (ASTM) 2001. ASTM Standard D 4442-92. Standard test methods for direct moisture content measurement of wood and wood-base materials. West Conshohocken, PA. p 510-515.

ASANTE, G.S. AND A.L NEAL. 1964. Characterization of fungistatic substances produced by a Bacillus antagonistic to Ceratocystis ulmi. Phytopathology 54(7): 819-822.

Barnett, J. A., R. W. PAYne, AND D. YArRow. 2000. Yeast: Characteristics and identification. $3^{\text {rd }}$ edition. Cambridge University Press. New York. p 882-887. 
BROWN, M. W. 1985. A Fortran program to calculate several diversity indices. USDA, Agric. Res. Serv. ARS-27: 1-24.

Chalutz, E. 1990. Postharvest biocontol of green and blue mold and sour rot of citrus fuits by Debaryomyces hansenii. Plant Disease 74(2):134-137.

Do CARMO-SousA, L. 1969. Distribution of yeast in nature. Pages 79-105 in Rose, A. H. and J. S. Harrison, eds. The Yeast. Vol. 1. Biology of the yeast. Academic press, Inc. London.

DowDY, S. AND S. WEARDEN. 1991. Statistics for research. $2^{\text {nd }}$ edition. John Wiley \& Sons, Inc. New York. p $348-352$.

DutKiewicz, J., C. Kwapiszewski, S. Olenchock, AND D. Lewis. 1992. Compact drill sampler for the quantitation of microorganisms in wood. United States Patent: 50378553.

Filonow, A. B., H. S. VishniaC, J. A. Anderson, And W. Jansiewicz. 1996. Biological control of Botrytis cinerea in apple by yeast from various habitats and their putative mechanisms of antagonism. Biol. Control 7:212-220.

GRAY, V.R. 1958. The acidity of wood. Journal of the institute of wood science. J. Institut. Wood Sci. 1: 58-64.

HeNNINGSSON, B. 1967. Interaction between microorganisms found in Birch and Aspen pulpwood. Stud. Forest. Suec. 53: 1-31.

Highley, T.L. AND LuTZ, J.F. 1970. Bacterial attack in water-stored bolts. Forest Prod. J. 20(4): 43-44.

JANISIEWICZ, W. J. 1988. Biocontrol of postharvest diseases of apples with antagonistic mixtures. Phytopathology 78: 194-198.

----------. 1994. Nutritional characterization of natural microflora of apple and its possible role in selection of biocontrol agents. Phytopathology 84:1152.

---------. 1998. Biocontrol of postharvest diseases of apples with antagonistic mixtures. Phytopathology 78: 194-198.

1996. Ecological diversity, niche overlap, and coexistence of antagonists used in developing mixtures for biocontrol of postharvest diseases of apples. Phytopathology 86: 473-479. 
, AND B. BORS. 1995. Development of a microbial community of bacterial and yeast antagonists to control wound-invading postharvest pathogens of fruits. Appl. Environ. Microbiol. 61(9): 3261-3267.

---------., J. USTALL, AND B. BORS. 1992. Nutritional enhancement of biological control of blue mold on apples. Phytopathology 82: 1364-1370.

KAARIK, A. 1975. Succession of microorganisms during wood decay. Pages 39-51 in W. Liese, ed. Biological transformation of wood by microorganisms. Springer. Berlin.

KANG, S., AND J. J. MorReLl. 2000. Fungal colonization of Douglas-fir sapwood lumber. Mycologia 92(4): 609-615.

KocH, P. 1985. Utilization of hardwoods growing on southern pine sites. USDA. For. Serv., Agric. Handbook. \#605 3710. U.S. Govt. Print. Off., Washington, D.C. p 452453.

KreBS, C. J. 1999. Ecological Methodology. $2^{\text {nd }}$ edition. Addison-Welsey Educational Publishers, Inc. Menlo Park, CA. p 410-446.

Kreger-VAn RiJ, N. J. W. 1969. Taxonomy and systematics of yeasts. Pages 66-86 in Rose, A. H. and J. S. Harrison (eds). The Yeast. Vol. I. Academic Press, Inc. London.

LAST, F. T. AND D. PricE. 1969. Yeast associated with living plants and their environments. Pages 190-218 in Rose, A. H. and J. S. Harrison (eds.). The Yeast. Vol. 1: Biology of the yeast. Academic Press, Inc. London.

LEDERER, E. 1933. C.r. hebd. Seanc. Acad. Sci. 197:1964-1965.

LEVY, J.F. 1975. Colonization of wood by fungi. Pages 16-23 in W. Liese, ed. Biological transformation of wood by microorganisms. Springer. Berlin.

Lindow, S. E. 1991. Determinants of epiphytic fitness in bacteria. Page 295 in J. H. Andrews and S. S. Hirano, eds. Microbial ecology of leaves. Springer-Verlag. New York.

---------. 1994. Epiphytic fitness determinants in bacteria. Page 29 in D. D. Bills and S. D. Kung, eds. Proceedings of the fourth international symposium, biotechnology and plant protection. World Scientific Publishing Co. Pte. Ltd. Singapore. River Edge. New Jersey. 
McCreary, M., B. CoesenzA, And A. L. Shigo. 1965. Bacteria isolated from decay and discoloration in northern hardwoods. Phytopathology 55(1): 129-130.

MERCIER, J. AND C. L. WILSON. 1994. Colonization of apple wounds by naturally occurring microflora and introduced Candida oleophila and their affects on infection by Botrytis cinerea during storage. Biological Control 4:138-144.

Moore, W. E., And D. B. Johnson. 1997. Procedures for the analysis of wood and wood products. USDA. For. Prod. Lab. For. Serv. Madison, WI. p 1-4.

Pasenen, A. L., T. Juutinen, M. J. Jantunen, And P. Kalliokoski. 1992. Occurrence and moisture requirements of microbial growth in building materials. Int. Biodet. Biodeg. 30: 273-283.

PAyne, C., A. BRUCE, AND H. Staines. 2000. Yeast and bacteria as biological control agents against fungal discoloration of Pinus sylvestris blocks in laboratory-based tests and the role of antifungal volatiles. Holzforshung 54: 563-569.

Pepper, I. L., C. P. Gerbe, AND J. W. Brendecke. 1995. Environmental Microbiology. Academic Press. San Diego, CA. p 27.

Rossell, S.E., E.G.M. ABbotT, And J.F. LeVy. 1973. Bacteria and wood. A review of the literature relating to the prescence, action and interaction of bacteria in wood. J. Wood Instit. Wood Sci. 32(6) No.2: 28-35.

SCHMIDT, O. 1985. Occurrence of microorganisms in the wood of Norway spruce trees from polluted sites. Eur. J. of Forest Pathol. 15: 1-10.

ShehatA, A. M., E. M. MraK, AND H. J. PhafF. 1955. Mycologia 47:799-811.

SHIGO, A.L. 1965. Decay and discoloration following logging wounds on the northern hardwoods. US Forest Serv. Res. Paper, NE-47.

---------., AND W. E. HILLIS. 1973. Heartwood, discolored wood, and microorganisms in living trees. Ann. Rev. Phytopathol. 11: 197-222.

Simpson, K. L., C. O. Chichester, AND H. J. Phaff. 1972. Carotenoid pigments of yeasts. Pages 493-515 in Rose, A. H. and J. S. Harrison, eds. The yeast. Vol. II. Physiology and Biochemistry of Yeasts. Academic Press, Inc. London.

Sorenson, W. G., J. SimPSON, AND J. DutKIEWICZ. 1991. Yeasts and yeast-like fungi in stored timber. Int. Biodet.27: 373-38. 
STOKES, J. L. 1971. Influence and temperature on the growth and metabolism of yeast. Pages 120-134 in Rose, A. H. and J.S. Harrison (eds). The yeast. Vol.II. Physiology and biochemistry of yeast. Academic Press, Inc. London.

SuOmalainen, H. AND E. OuRA. 1971. Yeast nutrition and solute uptake. Pages 3-37 in Rose, A. H. and J.S. Harrison (eds). The yeast. Vol.II. Physiology and Biochemistry of yeast. Academic Press, Inc. London.

WalKer, G. M. AND A.H. MCLEOD. 1995. Activity of killer yeasts against plant pathogenic and wood biodeteriogenic fungi. Pages 91-104 in R. Miller, ed. MicrobePlant Interactions. Greenwich University Press.

WANG, C.J.K. AND R.A. ZABEL. 1990. Identification manual for fungi from utility poles in the eastern United States. American type culture collection, Publisher. Rockwell, MD. 356pp.

WiLSON. M. AND S. E. LindOW. 1994. Ecological similarity and coexistence of epiphytic ice-nucleating Pseudomonas syringae strains and nonice-nucleating biological control agent. Appl. Environ. Microbiol. 60: 3128.

Wisniewsi, M., C. Biles, S. Droby, R. Mclaughlin, C. Wilson, and E. Chalutz. 1991. Mode of action of the postharvest biocontrol yeast, Pichia guilliermondi. Characterization of attachment to Botrytis cinerea. Physiological and Molecular Plant Path. 39:245-258. 
FIGURE 1. Increment borer used for taking moisture content and $\mathrm{pH}$ samples

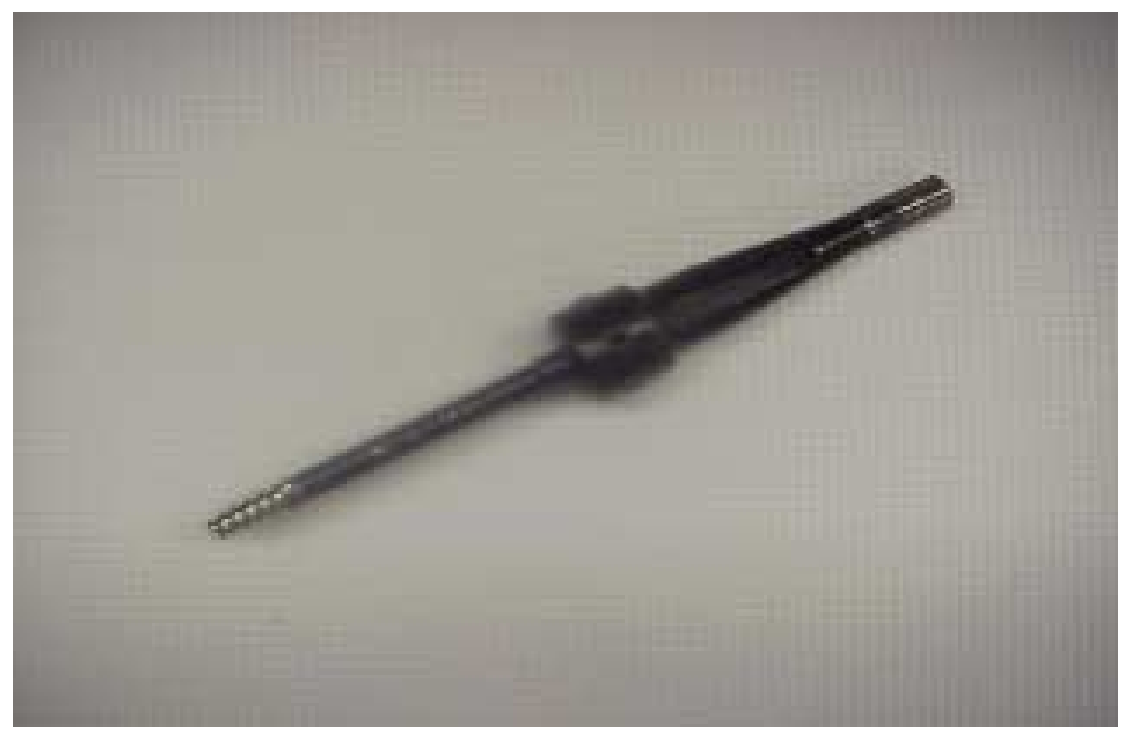

FIGURE 2. Seasonal comparison of yeast abundance isolated from dead-stacked yellowpoplar lumber in spring and summer of 2000.

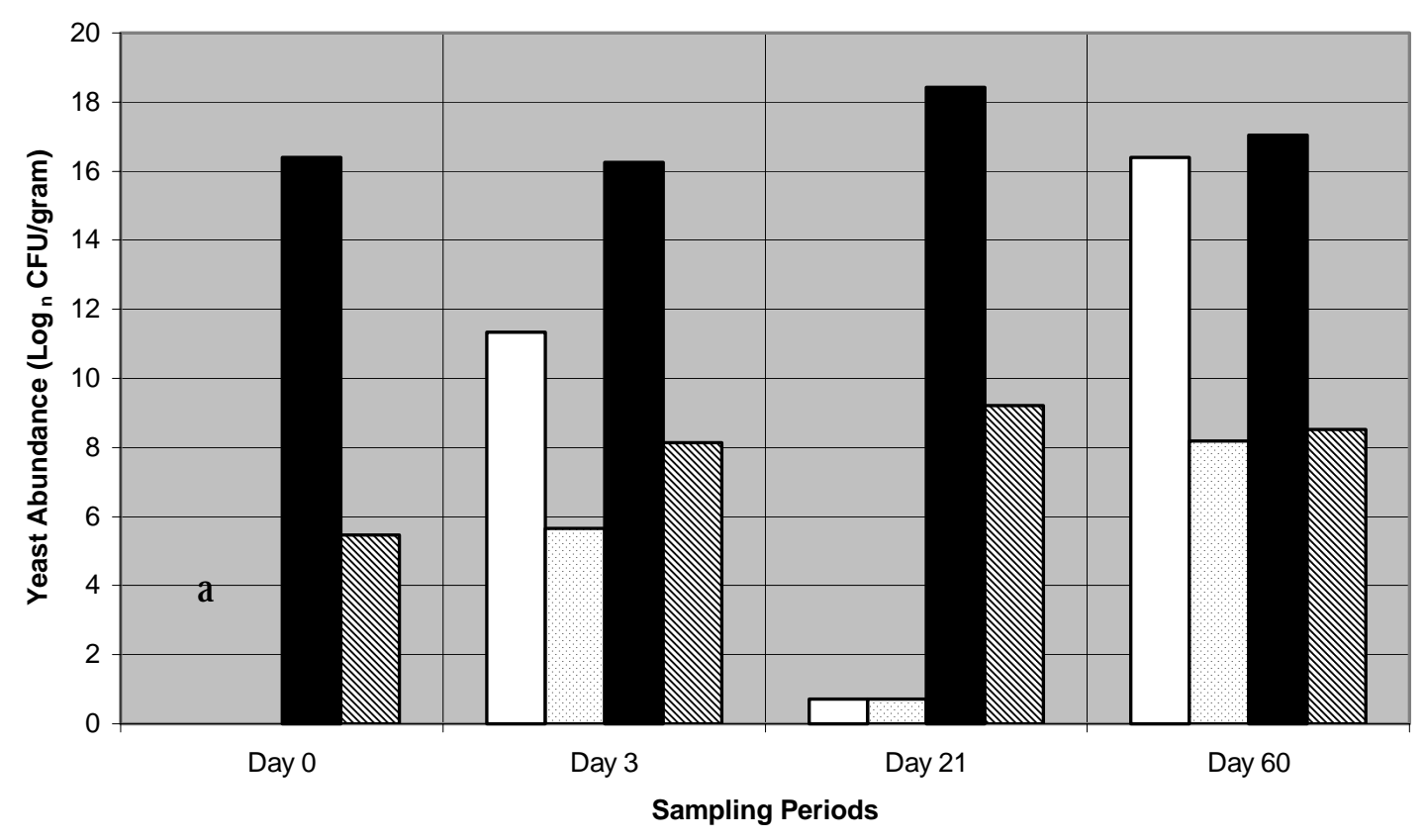

$\square$ Spring Total $\square$ Spring Ave $\square$ Summer Total $\mathbb{\$}$ Summer Ave

${ }^{a}$ Abundance data for Day 0 of spring was unavailable due to missing sample weight. 
FIGURE 3. Percent of the total abundance of microorganisms ( $\log _{n}$ CFU/gram) isolated from freshly sawn yellow poplar lumber stored in a dead-stack during spring and summer of 2000

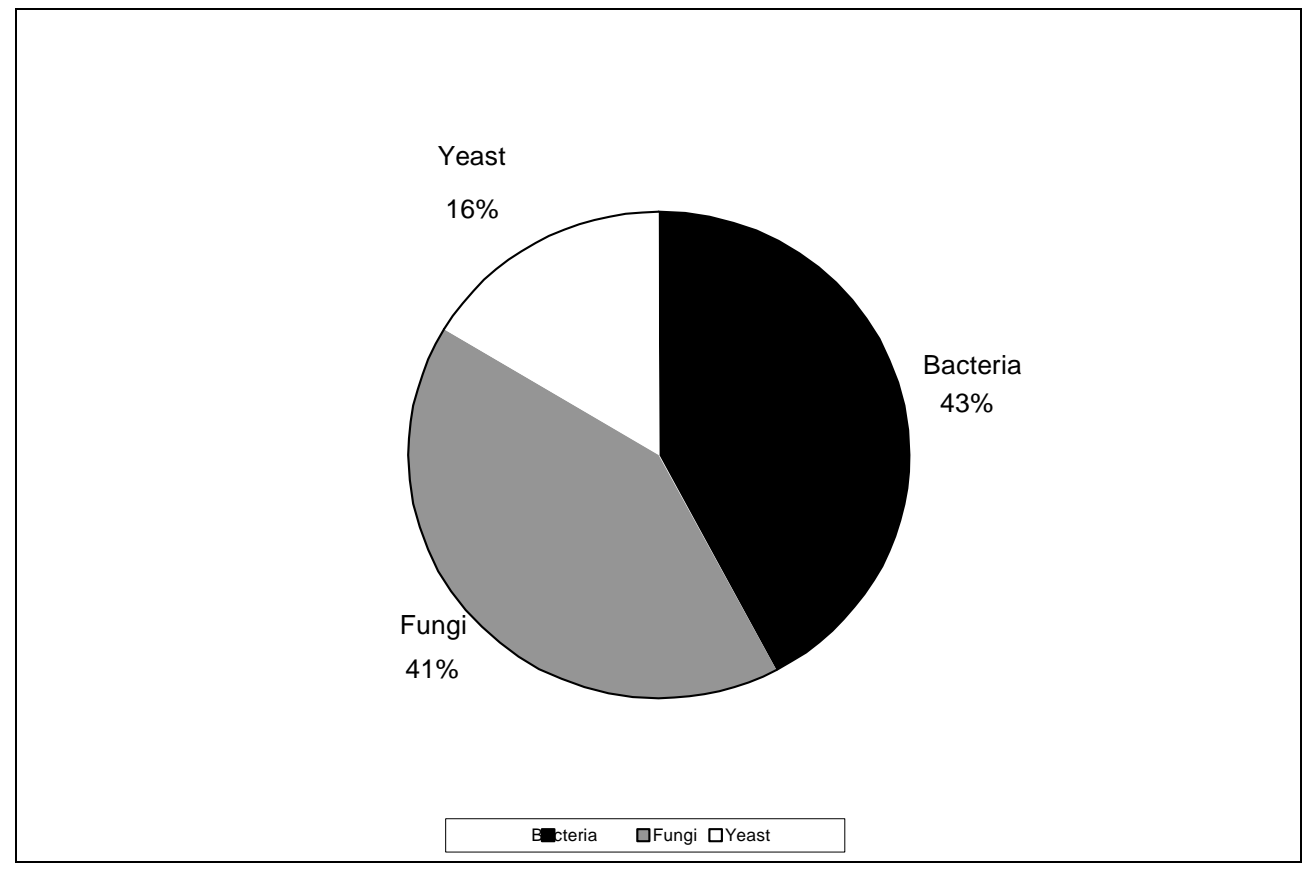

FIGURE 4. Comparison of yeast species isolated and positively identified from deadstacked yellow-poplar lumber in spring and summer of 2000.

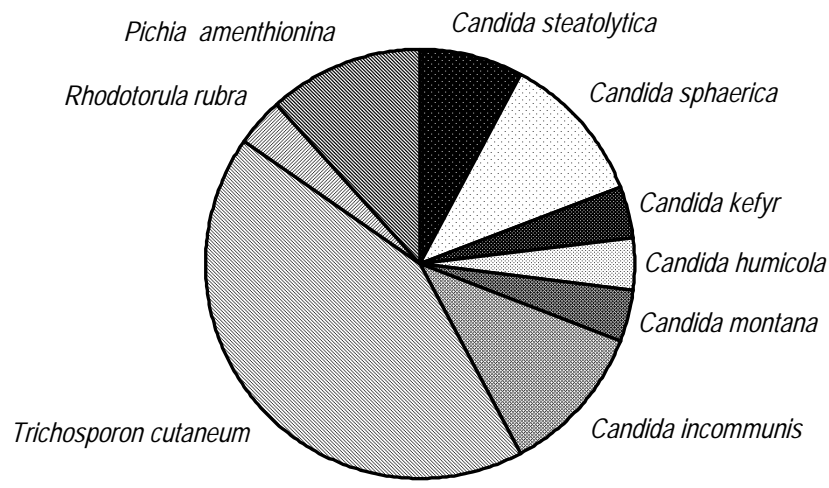

Candida steatolytica

$\square$ Candida sphaerica

Candida kefyr

- Candida humicola

圆 Candida montana

Candida incommunis

Trichosporon cutaneum

Rhodotorula rubra

Pichia amenthionina 
TABLE 1. Abundance of yeast per sampling period during spring and summer of 2000.

\section{Yeast Abundance}

\begin{tabular}{|c|c|c|c|c|}
\hline & & & \multirow{2}{*}{\multicolumn{2}{|c|}{ Summer }} \\
\hline \multirow{2}{*}{$\begin{array}{c}\text { Days of } \\
\text { Sampling }\end{array}$} & \multicolumn{2}{|c|}{ Spring } & & \\
\hline & $\begin{array}{c}\log _{n} \\
\text { CFU/gram }\end{array}$ & CFU/gram & $\begin{array}{c}\log _{n} \\
\text { CFU/gram }\end{array}$ & CFU/gram \\
\hline Day 0 Total & $\mathrm{m}$ & $\mathrm{m}$ & 16.4 & $7.4 \mathrm{E}+03$ \\
\hline Day 0 Average & $\mathrm{m}$ & $\mathrm{m}$ & 5.5 & $2.5 \mathrm{E}+03$ \\
\hline Day 3 Total & 11.3 & $3.2 \mathrm{E}+04$ & 16.3 & $7.5 \mathrm{E}+03$ \\
\hline Day 3 Average & 5.7 & $1.1 \mathrm{E}+04$ & 8.1 & $2.5 \mathrm{E}+03$ \\
\hline Day 21 Total & 0.7 & $2.1 \mathrm{E}+00$ & 18.4 & $2.6 \mathrm{E}+04$ \\
\hline Day 21Average & 0.7 & $6.9 \mathrm{E}+-01$ & 9.2 & $8.6 \mathrm{E}+03$ \\
\hline Day 60 Total & 16.4 & $4.5 \mathrm{E}+06$ & 17.0 & $1.0 \mathrm{E}+04$ \\
\hline Day 60Average & 8.2 & $1.5 \mathrm{E}+06$ & 8.5 & $3.4 \mathrm{E}+03$ \\
\hline Total & 28.4 & $4.5 \mathrm{E}+06$ & 68.1 & $4.1 \mathrm{E}+04$ \\
\hline Average & 9.5 & $1.5 \mathrm{E}+06$ & 17.0 & $1.0 \mathrm{E}+04$ \\
\hline
\end{tabular}

${ }^{\mathrm{m}}$ Abundance of yeast could not be calculated due to missing sample weight.

TABLE 2. Succession of yeast isolated from dead-stacked yellow-poplar lumber during spring and summer of 2000.

\begin{tabular}{|c|c|c|c|c|c|c|c|c|}
\hline \multirow{4}{*}{ Yeast } & \multicolumn{8}{|c|}{ Succession of Yeast } \\
\hline & \multicolumn{8}{|c|}{ Sampling Days in Spring and Summer } \\
\hline & \multicolumn{2}{|c|}{0} & \multicolumn{2}{|c|}{3} & \multicolumn{2}{|c|}{21} & \multicolumn{2}{|c|}{60} \\
\hline & Spring & Summer & Spring & Summer & Spring & Summer & Spring & Summer \\
\hline Candida sphaerica & $\mathrm{X}$ & \multirow{6}{*}{$\mathrm{X}$} & & & & \multirow{8}{*}{ X } & \multirow{6}{*}{$\mathrm{X}$} & \multirow{9}{*}{$\mathrm{X}$} \\
\hline C. kefyr & $\mathrm{X}$ & & & & & & & \\
\hline C. montanta & $\mathrm{X}$ & & & & & & & \\
\hline C. steatolytica & $\mathrm{X}$ & & & & & & & \\
\hline C. humicola & & & & & & & & \\
\hline C. incommunis & & & & & & & & \\
\hline Trichosporon cutaneum & & \multirow[t]{3}{*}{$\mathrm{X}$} & \multirow{3}{*}{$\mathrm{X}$} & $\mathrm{x}$ & $\mathrm{x}$ & & $\mathrm{X}$ & \\
\hline Rhodotorula rubra & & & & & & & & \\
\hline Pichia amenthionina & & & & $\mathrm{x}$ & & $\mathrm{x}$ & & \\
\hline
\end{tabular}

$\mathrm{X}$ Denotes identification of yeast on the designated sampling date. 


\section{EPILOGUE}

The main objective to characterize and identify the abundance of microorganisms colonizing freshly sawn yellow-poplar lumber at various sampling dates in the first 60 days of storage in two seasons (spring and summer) was accomplished. Although many additional physical factors influence the colonization pattern of microflora of wood than those monitored during this study, some findings stand out.

1. The moisture content of lumber in a dead-stack configuration remained higher than lumber in a typical industry standard stickered stack during the first 60 days of storage after sawing.

2. Variation in daily and seasonal temperature during spring and summer did not affect the abundance of fungi and yeast when tested statistically $(\mathrm{P}>0.05)$.

3. The abundance of bacteria was significantly $(\mathrm{P}<0.05)$ different between spring and summer.

4. Of the microorganisms sampled in this study, bacteria occupied the greatest portion of the total population, accounting for $43 \%$.

5. Freshly sawn lumber is susceptible to immediate colonization or contamination by fungi, bacteria, and yeast. This immediate development could be a result of several factors including: infection before processing; infection by microorganisms commonly isolated from the air, by the saw blade (itself) functioning as an inoculating instrument, or by a combination of these factors. In order to determine the vector for microorganism colonization further research is required.

The wood industry suffers considerable loss in revenue each year due to discoloration caused by mold and sapstain fungi. Although the chemical preservatives currently employed are effective, increasing regulations of chemical biocides is forcing preservatives to move in a more environmentally friendly direction. Research is ongoing to develop an 
alternative preservative for controlling problems of wood biodeterioration (discoloration/decay) and is heading toward biological control. Biological Control Agents (BCAs) are inexpensive and exist as part of the normal microflora. In the agricultural industry, in particular post-harvest fruit, it has been proven that this type of preservative treatment is possible. Due to the absence of studies identifying the microorganisms of the target substrate (hardwood lumber) for these preservatives, this study may provide valuable information to aid in the development of this type of BCA. Some of the microorganisms isolated during this study could be potentially used BCAs. Further research is required to fully understand this niche, its microflora, and the affecting factors; however, this study should provide a solid baseline for future research in this area. 